Prepared in cooperation with the Alaska Volcano Observatory, a cooperative program of the U.S. Geological Survey, the University of Alaska Fairbanks Geophysical Institute, and the Alaska Division of Geological \& Geophysical Surveys

\title{
2017 Volcanic Activity in Alaska-Summary of Events and Response of the Alaska Volcano Observatory
}

Scientific Investigations Report 2020-5102 
Cover. Photograph of Bogoslof volcano showing a vigorous steam plume likely caused by interaction of a new, hot lava dome into seawater. Photograph by Dave Withrow, National Oceanic and Atmospheric Administration (NOAA), taken about 13 nautical miles from Bogoslof Island on August 26, 2017, aboard a NOAA twin otter (N56RF) aircraft while surveying harbor seals west of Dutch Harbor. 


\section{Volcanic Activity in Alaska-Summary of Events and Response of the Alaska Volcano Observatory}

By James P. Dixon, Cheryl E. Cameron, Alexandra M. lezzi, John A. Power, Kristi Wallace, and Christopher F. Waythomas

Prepared in cooperation with the Alaska Volcano Observatory, a cooperative program of the U.S. Geological Survey, the University of Alaska Fairbanks Geophysical Institute, and the Alaska Division of Geological \& Geophysical Surveys

Scientific Investigations Report 2020-5102 


\title{
U.S. Department of the Interior DAVID BERNHARDT, Secretary
}

\author{
U.S. Geological Survey \\ James F. Reilly II, Director
}

U.S. Geological Survey, Reston, Virginia: 2020

For more information on the USGS - the Federal source for science about the Earth, its natural and living resources, natural hazards, and the environment-visit https://www.usgs.gov or call 1-888-ASK-USGS (1-888-275-8747).

For an overview of USGS information products, including maps, imagery, and publications, visit https://store.usgs.gov.

Any use of trade, firm, or product names is for descriptive purposes only and does not imply endorsement by the U.S. Government.

Although this information product, for the most part, is in the public domain, it also may contain copyrighted materials as noted in the text. Permission to reproduce copyrighted items must be secured from the copyright owner.

Suggested citation:

Dixon, J.P., Cameron, C.E., lezzi, A.M., Power, J.A., Wallace, K., and Waythomas, C.F., 2020, 2017 Volcanic activity in Alaska-Summary of events and response of the Alaska Volcano Observatory: U.S. Geological Survey Scientific Investigations Report 2020-5102, 61 p., https://doi.org/10.3133/sir20205102.

ISSN 2328-0328 (online) 


\section{Contents}

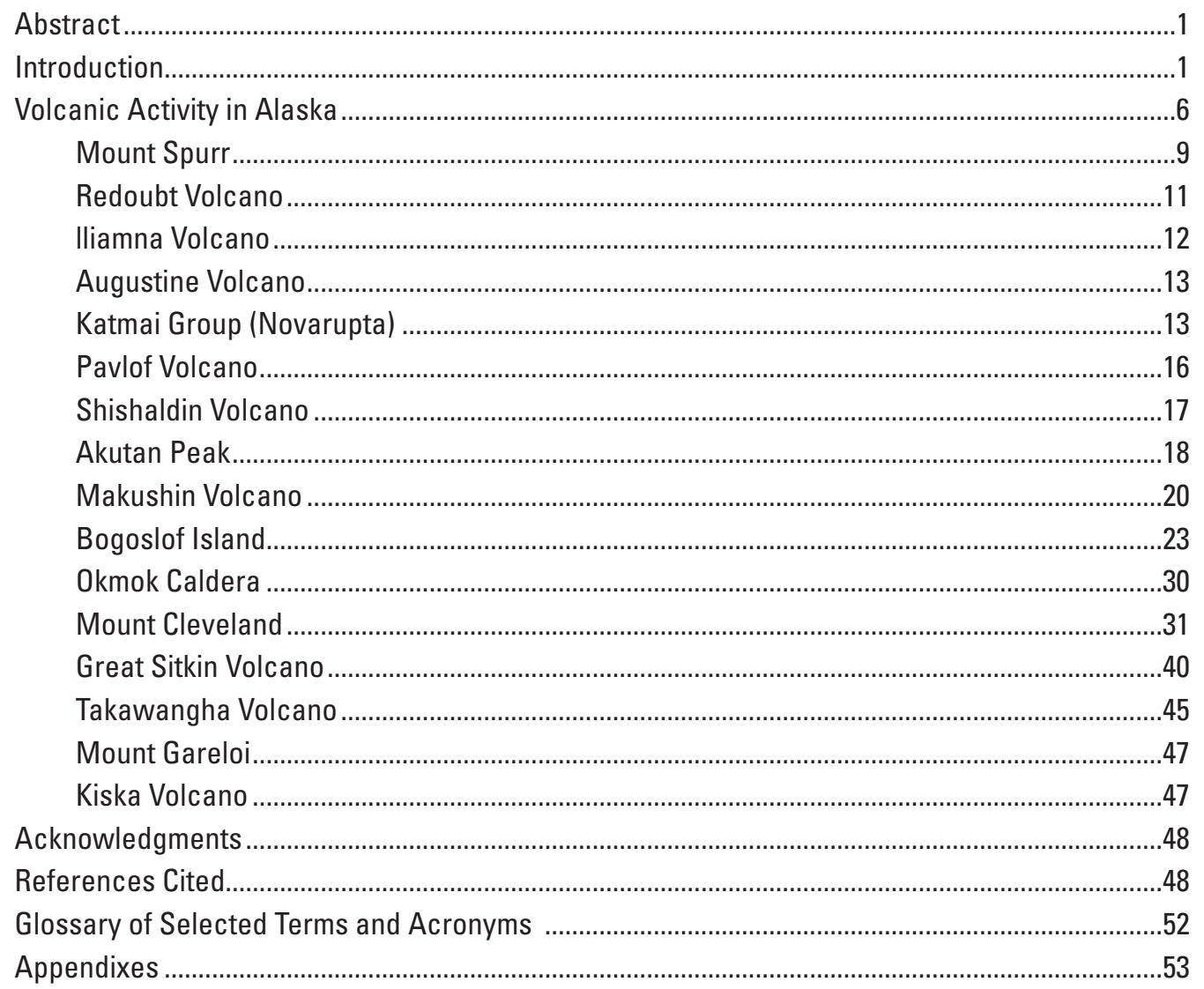




\section{Figures}

1. Map showing 54 historically active volcanoes in Alaska, their monitored status, and place names used in this report..

2. Epicentral map showing clusters of seismicity near Mount Spurr in 2017.....................10

3. Aerial photograph of the summit of Mount Spurr on April 20, 2017 ..............................11

4. Aerial photograph of the 2009 lava dome on Redoubt Volcano on May 27, 2018 ............11

5. Photograph from March 17, 2017, of a debris flow on the west flank near the summit of lliamna Volcano spotted by a citizen observer...

6. Alaska Volcano Observatory web-camera image from April 13,2017 , of a debris flow on the east side of Iliamna Volcano.

7. Aerial photograph of degassing from the two main fumarole fields on the east flank of Iliamna Volcano on April 20, 2017 ........................................................................................... 12

8. U.S. Geological Survey photograph of Augustine Island and Volcano ............................13

9. False color satellite images of June 4, 2017, ash resuspension event.................................14

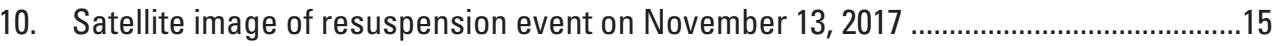

11. U.S. Geological photograph of River Lethe in Katmai National Park and Preserve, Valley of Ten Thousand Smokes, showing Mount Griggs in the background 15

12. NOAA-18 mid-IR satellite image of moderate surface temperatures at Pavlof

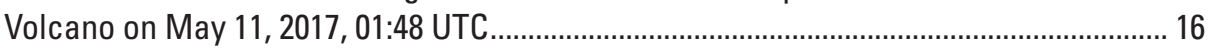

13. Photograph of Pavlof Volcano on June 14, 2015 ........................................................17

14. Graphs showing infrasound detection of Shishaldin Volcano on November 30, 2017, observed from the Sand Point, Alaska, infrasound array .......................................................... 18

15. U.S. Geological Survey photograph of Shishaldin Volcano taken on August 7, 2018, by Matt Loewen .................................................................................18

16. Map of and graph showing seismicity for Akutan Island in 2017 ……..........................19

17. Aerial photograph of Akutan volcano taken by Vlad Karpayev................................................. 20

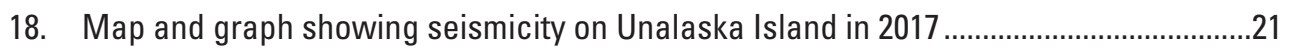

19. Bar graphs showing earthquake comparison at Makushin Volcano between 2002 and 2017

20. Photograph of Makushin Volcano showing a gas plume rising from the summit region viewed from Dutch Harbor on December 25, 2017 ...........................................22

21. Bar graphs showing number of detected explosive events per month ...........................23

22. Map of area around Bogoslof Island showing the location of seismograph and infrasound stations that were prominent in monitoring the 2016-17 Bogoslof volcano eruption

23. Diagrams showing the changes in the morphology of Bogoslof Island resulting from eruptive activity, December 25, 2016, to September 18, 2017.

24. U.S. Geological Survey photograph of Bogoslof Island from the northwest on August 16, 2018, showing the domes above sea level.

25. Photograph of Okmok Caldera looking east from the caldera rim on July 16, 2018 ................... 31

26. Infrasound waveform graphs showing the March 24, 2017, explosion of Mount Cleveland volcano at the station CLES located about $3.5 \mathrm{~km}$ from the summit.. .37 
27. Worldview3 satellite base image and digital sketches of the three lava domes in Mount Cleveland's summit crater from April 15 to 28, 2017.

28. Seismic waveform and spectrogram graphs showing the July 4, 2017, explosion of Mount Cleveland

29. Photograph of a small lava dome in the summit crater of Mount Cleveland volcano on August 17, 2017

30. Several graphs of processed data from the station CLCO infrasound array for the September 26, 2017, Mount Cleveland explosion showing an initial blast followed by a brief pause and 2 minutes of jetting

31. NOAA-19 thermal infrared brightness temperature difference image showing the December 13, 2017, eruption cloud drifting east

32. Map and graph of Great Sitkin Volcano showing earthquakes located in 2016 and 2017

33. Plot showing earthquake focal depth versus time for January 1, 2016, through December 31, 2017

34. Waveform and spectrogram showing a magnitude -0.40 deep long-period event located under the north flank of Great Sitkin Volcano at 14:53 UTC on July 30, 2016, at a depth of $16.7 \mathrm{~km}$.

35. Seismogram of seismograph station GSSP on January 11, 2017

36. Seismogram of seismograph station GSSP showing 24-hours of data starting at 18:00 UTC on July 21, 2017. Suspected explosions begin at 00:17 UTC and are followed by numerous small earthquakes.

37. Photograph of Great Sitkin Volcano as seen from Adak, Alaska, $42 \mathrm{~km}$ to the southwest, showing gas plume from the summit crater on November 19, 2017.

38. Map and graph earthquake of Tanaga Island showing earthquakes located from January 23 to February 28, 2017

39. U.S. Geological Survey photograph of Takawahgna volcano from the summit on the east side of Tanaga Volcano

40. U.S. Geological Survey photograph looking northwest to Mount Gareloi in August 2013

41. Photograph of Kiska Volcano showing gas plume from fumarolic field on the volcano's northwest flank

\section{Tables}

1. Summary of 2017 monitoring highlights at volcanoes in Alaska, including actual eruptions, possible eruptions, increases in seismicity, observations of fumarolic activity, and notable events

2. Alaska volcanoes with Aviation Color Code and Volcano Alert Level changes in 2017 ...3

3. Citations for Alaska Volcano Observatory annual summary reports, 1992-2016..............4

4. History of seismic monitoring of Alaska volcanoes from August 1971 through December 2017

5. Summary of significant events and Aviation Color Code and Volcanic Alert Level changes during the 2016-17 Bogoslof volcano eruption.

6. Summary of activity and observations at Mount Cleveland in 2017 .................................32 


\section{Conversion Factors}

International System of Units to U.S. customary units

\begin{tabular}{|c|c|c|}
\hline Multiply & By & To obtain \\
\hline \multicolumn{3}{|c|}{ Length } \\
\hline meter $(\mathrm{m})$ & 3.281 & foot $(\mathrm{ft})$ \\
\hline kilometer (km) & 3,281 & foot $(\mathrm{ft})$ \\
\hline kilometer (km) & 0.6214 & mile (mi) \\
\hline \multicolumn{3}{|c|}{ Velocity } \\
\hline kilometers per second $(\mathrm{km} / \mathrm{s})$ & 3,281 & feet per second $(\mathrm{ft} / \mathrm{s})$ \\
\hline \multicolumn{3}{|c|}{ Area } \\
\hline square meter $\left(\mathrm{m}^{2}\right)$ & 10.76 & square foot $\left(\mathrm{ft}^{2}\right)$ \\
\hline square kilometer $\left(\mathrm{km}^{2}\right)$ & 0.3861 & square mile $\left(\mathrm{mi}^{2}\right)$ \\
\hline \multicolumn{3}{|c|}{ Volume } \\
\hline cubic kilometer $\left(\mathrm{km}^{3}\right)$ & 0.2399 & cubic mile $\left(\mathrm{mi}^{3}\right)$ \\
\hline \multicolumn{3}{|c|}{ Mass flow } \\
\hline Tons per day (ton/d) & 0.9072 & metric tons per day (metric ton/d) \\
\hline
\end{tabular}

Temperature in degrees Celsius $\left({ }^{\circ} \mathrm{C}\right)$ may be converted to degrees Fahrenheit $\left({ }^{\circ} \mathrm{F}\right)$ as follows: ${ }^{\circ} \mathrm{F}=\left(1.8 \times{ }^{\circ} \mathrm{C}\right)+32$. 


\section{Datum}

Altitude and elevation as used in this report, refers to distance above sea level, unless otherwise noted.

Locations in latitude and longitude are presented in decimal degrees referenced to the WGS 1984 datum.

\section{Abbreviations}

$\begin{array}{ll}\text { AKDT } & \text { Alaska Daylight Time; UTC -8 hours } \\ \text { AKST } & \text { Alaska Standard Time; UTC -9 hours } \\ \text { ASL } & \text { above sea level } \\ \text { AVO } & \text { Alaska Volcano Observatory } \\ \text { DLP } & \text { deep long-period } \\ \text { GPS } & \text { Global Positioning System } \\ \text { GVP } & \text { Smithsonian Institution Global Volcanism Program } \\ \text { InSAR } & \text { Interferometric Synthetic Aperture Radar } \\ \text { NASA } & \text { National Aeronautics and Space Administration } \\ \text { NOAA } & \text { National Oceanic and Atmospheric Administration } \\ \text { NWS } & \text { National Weather Service } \\ \text { Pa } & \text { Pascal } \\ \text { PIREP } & \text { Pilot Weather Report } \\ \text { UAFGI } & \text { University of Alaska, Fairbanks Geophysical Institute } \\ \text { USGS } & \text { U.S. Geological Survey } \\ \text { UTC } & \text { Coordinated Universal Time; same as Greenwich Mean Time } \\ \text { VEI } & \text { Volcanic Explosivity Index } \\ \text { VTTS } & \text { Valley of Ten Thousand Smokes }\end{array}$





\title{
2017 Volcanic Activity in Alaska-Summary of Events and Response of the Alaska Volcano Observatory
}

\author{
By James P. Dixon, ${ }^{1}$ Cheryl E. Cameron, ${ }^{2}$ Alexandra M. Iezzi, ${ }^{3}$ John A. Power, ${ }^{1}$ Kristi L. Wallace, ${ }^{1}$ and \\ Christopher F. Waythomas ${ }^{1}$
}

\section{Abstract}

The Alaska Volcano Observatory responded to eruptions, significant and minor volcanic unrest, and seismic events at 16 volcanic centers in Alaska during 2017. The most notable volcanic activity consisted of a major eruption at Bogoslof Island, continuing intermittent dome growth and ash eruptions from Mount Cleveland, the end of the Pavlof Volcano eruption, volcanic unrest at Shishaldin Volcano, and significant earthquake activity at Tanaga and Great Sitkin Islands. This report also documents reports of degassing at Redoubt Volcano, Makushin Volcano, Mount Gareloi, and Kiska Volcano, anomalous seismicity at Mount Spurr, Augustine Volcano, Akutan Peak, and Makushin Volcano, landslides at Iliamna Volcano, resuspended ash from the 1912 Novarupta-Katmai eruption, and continuing inflation at Okmok Caldera.

\section{Introduction}

The Alaska Volcano Observatory (AVO) is responsible for monitoring, studying, and warning of hazards associated with volcanic unrest in Alaska (fig. 1). This report summarizes notable volcanic activity in Alaska during 2017 (tables 1 and 2) and briefly describes AVO's response. Information about all noteworthy episodes of volcanic unrest is included, even if no formal public notification was issued. Observations, images, and data that are typically not published elsewhere are included in this report. Descriptions of prominent eruptions are often a subject of stand-alone publications, and a series of papers describing the major eruption at Bogoslof Island has been recently published (Waythomas and others, 2019). Similar summaries of volcanic unrest and AVO's response have been published annually since 1992 (table 3).

The following descriptions of volcanic activity may use informal names for volcanoes. Many instances of the formal or official volcanic name do not coincide with the geographic or geologic extent of the volcano (for example, the Bogoslof

\footnotetext{
${ }^{1}$ U.S. Geological Survey.

${ }^{2}$ Alaska Division of Geological \& Geophysical Surveys.

${ }^{3}$ University of Alaska Fairbanks.
}

volcano [informal name] comprises more islands than Bogoslof Island [formal name], the Global Positioning System [GPS] network at the Akutan volcano monitors more than Akutan Peak). Some volcanoes lack an official place name (for example, Alagogshak). The informal volcano names in use by the AVO are defined within the discussions of each volcano's activity during 2017.

The AVO volcano-monitoring program includes daily analysis of satellite imagery, web-camera imagery, and seismicity; occasional overflights; airborne and ground-based gas measurements; and a compilation of visual reports from aircraft pilots (PIREPs), observatory personnel, local residents, and mariners. AVO also receives real-time deformation data from permanent Global Positioning System stations at eight Alaskan volcanoes (Akutan, Augustine, Makushin, Okmok, Redoubt, Shishaldin, Spurr, and Westdahl). Periodic analysis of the Ozone Mapping Instrument on NASA's Aura satellite (Lopez and others, 2013) and Interferometric Synthetic Aperture Radar (InSAR) imagery (for example, Lee and others, 2010) augments AVO's ability to monitor unrest at volcanoes in Alaska. AVO increasingly monitors Alaska volcanoes using infrasound sensors that measure atmospheric pressure waves to detect explosions (for example, Fee and others, 2010).

AVO scientists participate in a weekly duty, remotesensing rotation, and they produce a daily report that consists of a summary of all observation at any volcano at an elevated Aviation Color Code and Volcano Alert Level. Descriptions of any anomalies seen in satellite imagery and web cameras at the remaining volcanic centers AVO monitors are also included. The observations are created and archived in an internal database structure to assist in retrieving past observations. A second rotation of scientists from AVO and the National Earthquake Information Center monitors the seismicity at volcanoes with seismometers. Three separate reports are compiled daily approximately 8 hours apart and are crafted within a relational database.

Thirty-four of the fifty-four historically active volcanoes in Alaska were instrumented with a network of seismometers as of December 31, 2017 (table 4). Excluded from the formal list are those volcanoes that have insufficient seismic instrumentation to calculate reliable earthquake hypocenters and magnitudes or where real-time telemetry is not reliable enough to produce a complete record of earthquake activity. At Mount Cleveland only two seismograph stations are in operation, which is below 


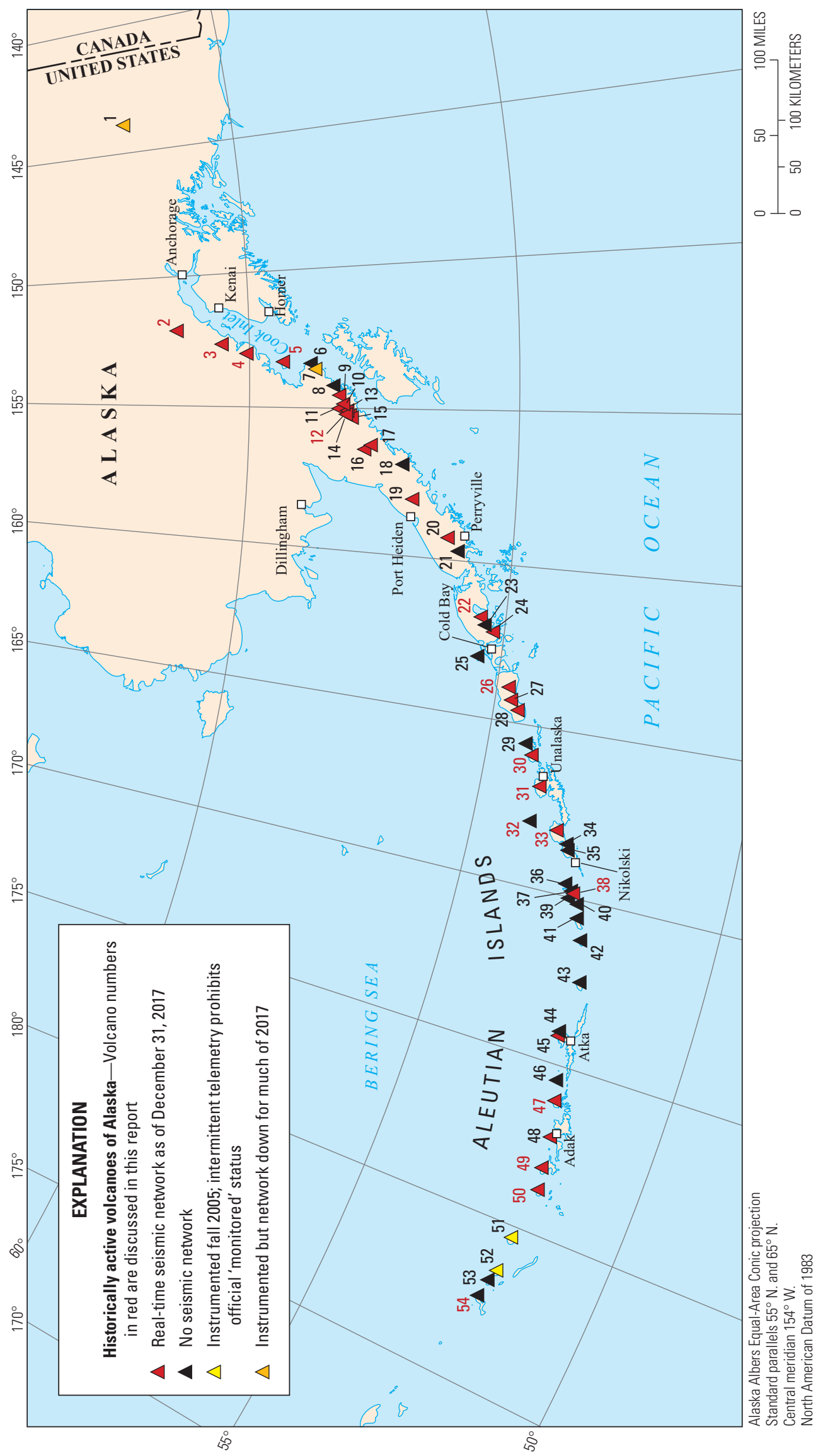

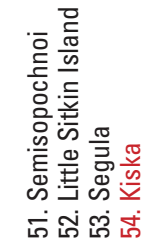

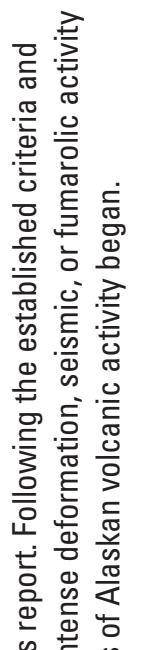

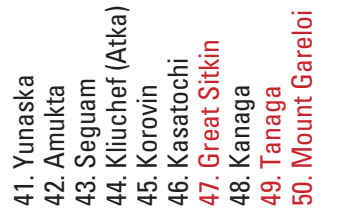

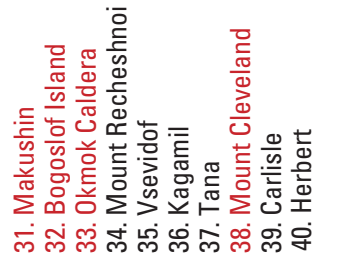

此送

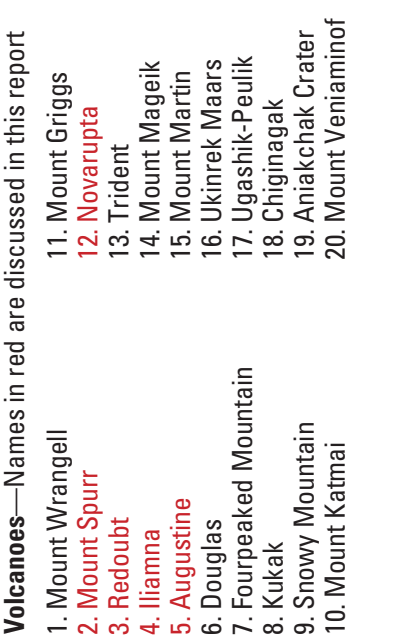

응

空

ه 훌

들. 들 둥

ه

远

票票

空空

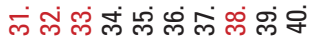

可

흘

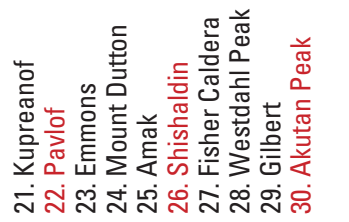

츨

宦

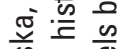

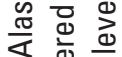

$\cong$ :을

๘

的

은

ग

密完

C)

칭

응 क्ष

홍

足

它吾导

옹ㅁㅇ

西

동ㅎㅁ임

要离

$\therefore$

인 3.

言竞焉 
Table 1. Summary of 2017 monitoring highlights at volcanoes in Alaska, including actual eruptions, possible eruptions, increases in seismicity, observations of fumarolic activity, and notable events.

[Cross-referenced lists of volcanic activity by year and by volcano for this and all previous Alaska Volcano Observatory annual activity reports are presented in appendix tables 2.1 and 2.2. Location of volcanoes shown in figure 1]

\begin{tabular}{lll}
\hline \multicolumn{1}{c}{ Volcano } & Date of activity & Type of activity \\
\hline Mount Spurr & Year-round & Earthquake swarm \\
Redoubt Volcano & April & Degassing \\
Iliamna Volcano & April & Minor snow and debris flow \\
Augustine Volcano & Year-round & Seismic activity \\
Katmai Group (Novarupta) & June, November & Resuspension of 1912 ash \\
Pavlof Volcano & January; May-August & End of intermittent eruption; volcanic unrest \\
Shishaldin Volcano & December & Volcanic unrest \\
Akutan Peak & November & Earthquake swarm \\
Makushin Volcano & Year-round; November & Earthquake swarm; degassing \\
Bogoslof Island & Year-round & Significant eruption \\
Okmok Caldera & Year-round & Inflation \\
Mount Cleveland & Year-round & Low-level eruption \\
Great Sitkin Volcano & January; July & Earthquake swarm; explosion \\
Takawangha volcano (Tanaga Island) & January & Earthquake swarm \\
\hline Mount Gareloi & March & Degassing \\
Kiska Volcano & November & Degassing \\
\hline
\end{tabular}

Table 2. Alaska volcanoes with Aviation Color Code and Volcano Alert Level changes in 2017.

[Dates are in 2017 unless otherwise indicated. Volcanoes with no elevated elevated alert level from Green and Normal throughout the year are not shown]

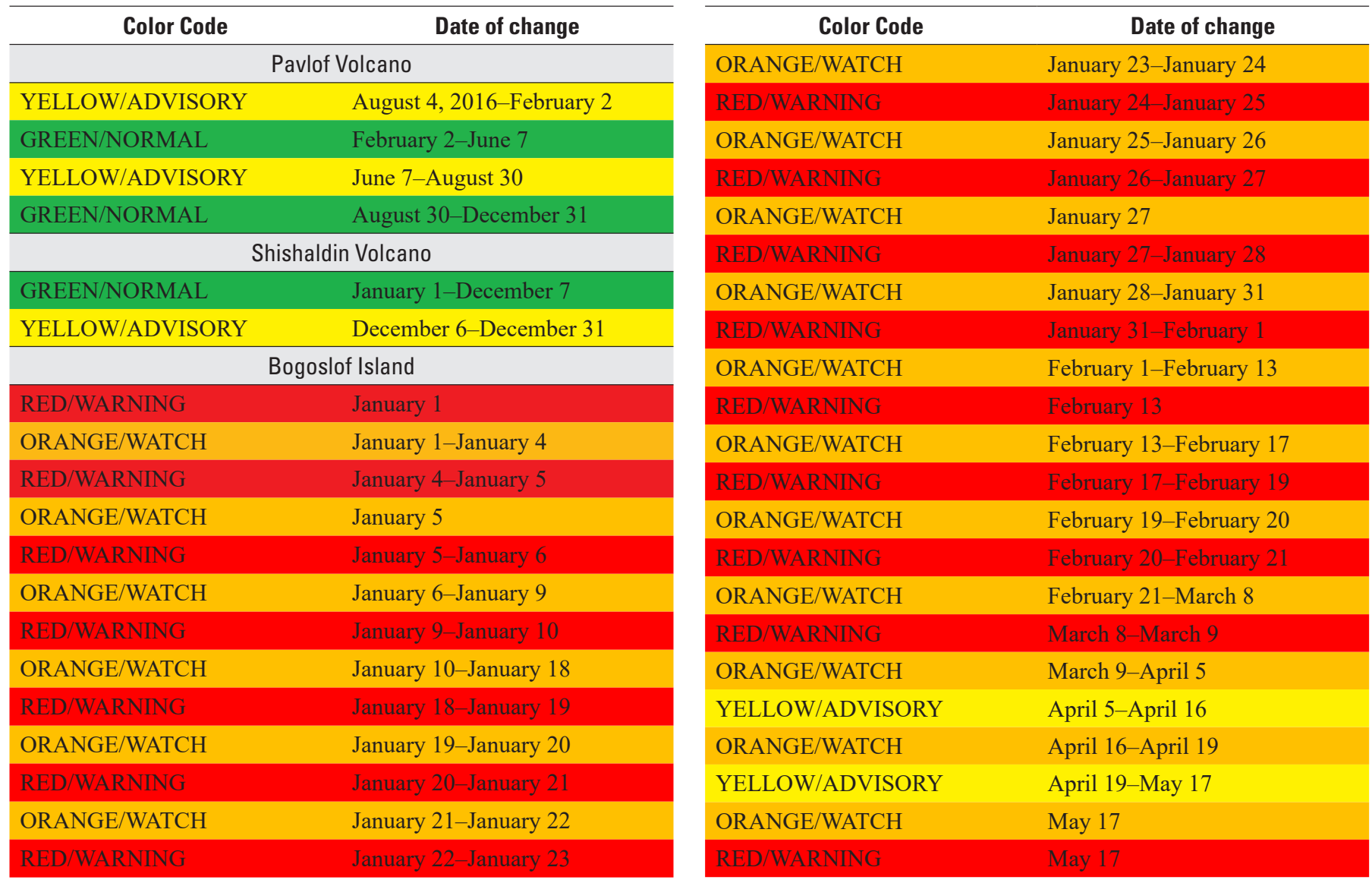


Table 2.-Continued

\begin{tabular}{ll}
\hline \multicolumn{1}{c}{ Color Code } & \multicolumn{1}{c}{ Date of change } \\
\hline ORANGE/WATCH & May 17-May 28 \\
\hline RED/WARNING & May 28-May 29 \\
\hline ORANGE/WATCH & May 29-June 10 \\
\hline RED/WARNING & June 10 \\
\hline ORANGE/WATCH & June 10-13 June \\
\hline RED/WARNING & 13 June \\
\hline ORANGE/WATCH & 13 June-24 June \\
\hline RED/WARNING & June 24 \\
\hline ORANGE/WATCH & June 24-27 June \\
\hline RED/WARNING & June 27 \\
\hline ORANGE/WATCH & June 27-July 2 \\
\hline RED/WARNING & July 2-July 3 \\
\hline ORANGE/WATCH & July 3-July 5 \\
\hline RED/WARNING & July 5 \\
\hline ORANGE/WATCH & July 5-July 8 \\
\hline RED/WARNING & July 8-July 9 \\
\hline ORANGE/WATCH & July 9-July 10 \\
\hline RED/WARNING & July 10 \\
\hline ORANGE/WATCH & July 10-August 7 \\
\hline RED/WARNING & August 7-August 8 \\
\hline
\end{tabular}

\begin{tabular}{ll}
\hline \multicolumn{1}{c}{ Color Code } & \multicolumn{1}{c}{ Date of change } \\
\hline ORANGE/WATCH & August 8-September 27 \\
\hline YELLOW/ADVISORY & September 27-December 6 \\
\hline UNASSIGNED & December 6-December 31 \\
\hline \multicolumn{2}{c}{ Mount Cleveland } \\
\hline YELLOW/ADVISORY & November 4, 2016-February 3 \\
\hline ORANGE/WATCH & February 3-March 8 \\
\hline YELLOW/ADVISORY & March 8-March 24 \\
\hline ORANGE/WATCH & March 24-April 5 \\
\hline YELLOW/ADVISORY & April 5-April 24 \\
\hline ORANGE/WATCH & April 24-June 26 \\
\hline YELLOW/ADVISORY & June 26-July 4 \\
\hline ORANGE/WATCH & July 4-December 12 \\
\hline YELLOW/ADVISORY & December 12-February 9, 2018 \\
\hline & Great Sitkin Volcano \\
\hline GREEN/NORMAL & January 1-November 22 \\
\hline YELLOW/ADVISORY & November 22-December 31 \\
\hline & Takawangha volcano \\
\hline GREEN/NORMAL & January 1-January 24 \\
\hline YELLOW/ADVISORY & January 24-February 8 \\
\hline GREEN/NORMAL & February 8-December 31 \\
\hline
\end{tabular}

Table 3. Citations for Alaska Volcano Observatory annual summary reports, 1992-2016.

\begin{tabular}{|c|c|c|}
\hline Year & Citation & URL \\
\hline 1992 & $\begin{array}{l}\text { McGimsey, R.G., Neal, C.A., and Doukas, M.P., 1995, Volcanic activity in Alaska: Summary of } \\
\text { events and response of the Alaska Volcano Observatory 1992: U.S. Geological Survey Open-File } \\
\text { Report 95-83, } 26 \text { p. }\end{array}$ & https://doi.org/10.3133/ofr9583 \\
\hline 1993 & $\begin{array}{l}\text { Neal, C.A., McGimsey, R.G., and Doukas, M.P., 1996, } 1993 \text { volcanic activity in Alaska: Summary of } \\
\text { events and response of the Alaska Volcano Observatory: U.S. Geological Survey Open-File Report } \\
\text { 96-0024, } 21 \text { p. }\end{array}$ & https://pubs.usgs.gov/of/1996/0024/ \\
\hline 1995 & $\begin{array}{l}\text { McGimsey, R.G., and Neal, C.A., 1996, } 1995 \text { Volcanic activity in Alaska and Kamchatka: Summary } \\
\text { of events and response of the Alaska Volcano Observatory: U.S. Geological Survey Open-File } \\
\text { Report } 96-0738,22 \text { p. }\end{array}$ & https://pubs.usgs.gov/of/1996/0738/ \\
\hline 1996 & $\begin{array}{l}\text { Neal, C.A., and McGimsey, R.G., 1997, } 1996 \text { Volcanic activity in Alaska and Kamchatka: Summary } \\
\text { of events and response of the Alaska Volcano Observatory: U.S. Geological Survey Open-File } \\
\text { Report } 97-0433,34 \text { p. }\end{array}$ & https://pubs.usgs.gov/of/1997/0433/ \\
\hline 1998 & $\begin{array}{l}\text { McGimsey, R.G., Neal, C.A., and Girina, Olga, 2003, } 1998 \text { Volcanic activity in Alaska and } \\
\text { Kamchatka: Summary of events and response of the Alaska Volcano Observatory: U.S. Geological } \\
\text { Survey Open-File Report 03-0423, } 35 \text { p. }\end{array}$ & https://doi.org/10.3133/ofr03423 \\
\hline
\end{tabular}


Table 3.-Continued

\begin{tabular}{cc}
\hline Year & Citation \\
\hline 1999 McGimsey, R. G., Neal, C. A., and Girina, Olga, 2004a, 1999 Volcanic activity in Alaska and \\
Kamchatka: Summary of events and response of the Alaska Volcano Observatory: U.S. Geological \\
Survey OpenFile Report OF 2004-1033, 49 p.
\end{tabular}

2002 Neal, C.A., McGimsey, R.G., and Girina, Olga, 2005, 2002 Volcanic activity in Alaska and

https://doi.org/10.3133/ofr20041058 Kamchatka: Summary of events and response of the Alaska Volcano Observatory: U.S. Geological Survey OpenFile Report 2004-1058, 51 p.

2003 McGimsey, R.G., Neal, C.A., and Girina, Olga, 2005, 2003 Volcanic activity in Alaska and Kamchatka: Summary of events and response of the Alaska Volcano Observatory: U.S. Geological Survey OpenFile Report 2005-1310, 58 p.

2004 Neal, C.A., McGimsey, R.G., Dixon, J.P., and Melnikov, Dmitry, 2005, 2004 Volcanic activity in Alaska and Kamchatka: Summary of events and response of the Alaska Volcano Observatory: U.S. Geological Survey OpenFile Report 2005-1308, 67 p.

2005 McGimsey, R.G., Neal, C.A., Dixon, J.P., and Ushakov, Sergey, 2007, 2005 Volcanic activity in Alaska, Kamchatka, and the Kurile Islands: Summary of events and response of the Alaska Volcano Observatory: U.S. Geological Survey Scientific Investigations Report 2007-5269, 94 p.

2006 Neal, C.A., McGimsey, R.G., Dixon, J.P., Manevich, Alexander, and Rybin, Alexander, 2009, 2006 Volcanic activity in Alaska, Kamchatka, and the Kurile Islands: Summary of events and response of the Alaska Volcano Observatory: U.S. Geological Survey Scientific Investigations Report 20085214, $102 \mathrm{p}$.

2007 McGimsey, R.G., Neal, C.A., Dixon, J.P., Malik, Nataliya, and Chibisova, Marina, 2011, 2007 Volcanic activity in Alaska, Kamchatka, and the Kurile Islands: Summary of events and response of the Alaska Volcano Observatory: U.S. Geological Survey Scientific Investigations Report 2010$5242,110 \mathrm{p}$.

2008 Neal, C.A., McGimsey, R.G., Dixon, J.P., Cameron, C.E., Nuzhaev, A.A., and Chibisova, Marina, 2011, 2008 Volcanic activity in Alaska, Kamchatka, and the Kurile Islands: Summary of events and response of the Alaska Volcano Observatory: U.S. Geological Survey Scientific Investigations Report 2010-5243, 94 p.

2009 McGimsey, R.G., Neal, C.A., Girina, O.A., Chibisova, Marina, and Rybin, Alexander, 2014, 2009 Volcanic activity in Alaska, Kamchatka, and the Kurile Islands - summary of events and response of the Alaska Volcano Observatory: U.S. Geological Survey Scientific Investigations Report 2013$5213,125 \mathrm{p}$.

2010 Neal, C.A., Herrick, J., Girina, O.,A., Chibisova, M., Rybin, A., McGimsey, R.G., and Dixon, J., 2014, 2010 Volcanic activity in Alaska, Kamchatka, and the Kurile Islands - Summary of events and response of the Alaska Volcano Observatory: U.S. Geological Survey Scientific Investigations Report 2014-5034, 76 p.

2011 McGimsey, R.G., Maharrey, J.Z., and Neal, C.A., 2014, 2011 Volcanic activity in Alaska-Summary of events and response of the Alaska Volcano Observatory: U.S. Geological Survey Scientific Investigations Report 2014-5159, 50 p.

2012 Herrick, J.A., Neal, C.A., Cameron, Cheryl, Dixon, Jim, and McGimsey, R.G., 2014, 2012 Volcanic activity in Alaska-Summary of events and response of the Alaska Volcano Observatory: U.S. Geological Survey Scientific Investigations Report 2014-5160, 80 p.

2013 Dixon, J.P., Cameron, Cheryl, McGimsey, R.G., Neal, C.A., and Waythomas, Chris, 2015, 2013 Volcanic activity in Alaska-Summary of events and response of the Alaska Volcano Observatory: U.S. Geological Survey Scientific Investigations Report 2015-5110, 92 p.

https://doi.org/10.3133/ofr20041453

https://doi.org/10.3133/ofr20041033

https://doi.org/10.3133/ofr20041034

ps.//doi.org/10.3133/ofr20041034

https://doi.org/10.3133/ofr20051310

(n)

https://doi.org/10.3133/ofr20051308

https://doi.org/10.3133/sir20075269

https://doi.org/10.3133/sir20085214

\author{
https
}

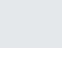

https://doi.org/10.3133/sir20105242

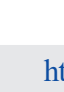


Table 3.-Continued

\begin{tabular}{|c|c|c|}
\hline Year & Citation & URL \\
\hline 15 & $\begin{array}{l}\text { Dixon, J.P., Cameron, C.E., Iezzi, A.M., and Wallace, Kristi, 2017, } 2015 \text { Volcanic activity in Alaska- } \\
\text { Summary of events and response of the Alaska Volcano Observatory: U.S. Geological Survey } \\
\text { Scientific Investigations Report 2017-5104, } 81 \text { p. }\end{array}$ & https://doi.org/10.3133/sir20175104 \\
\hline 2016 & $\begin{array}{l}\text { Cameron, C.E., Dixon, J.P., Waythomas, C.F., Iezzi, A.M., Wallace, K., McGimsey, R.G., and Bull, K.F., } \\
\text { 2020, } 2016 \text { Volcanic activity in Alaska-Summary of events and response of the Alaska Volcano } \\
\text { Observatory: U.S. Geological Survey Scientific Investigations Report 2020-5125, } 63 \text { p. }\end{array}$ & https://doi.org/10.3133/sir20205125 \\
\hline
\end{tabular}

What is an "eruption"?

The specific use of the term "eruption" varies from scientist to scientist, and there is no universally agreed-upon definition. Here, we adopt the usage of the Smithsonian Institution's Global Volcanism Program, which defines eruptions as “....events that involve the explosive ejection of fragmental material, the effusion of liquid lava, or both." (Siebert and others, 2010). The elements of this definition that are emphasized are the verbs "eject" and "effuse," which refer to dynamic surface processes that pose some level of hazard. The presence or absence of the terms "juvenile material" or "fresh magma" is not relevant to this use of the term eruption, particularly when communicating a potential hazard. This definition would not, however, include passive volcanic degassing or hydrothermal-fluid discharge.

\section{What is a "historically active volcano"?}

AVO defines an "active" volcano as a volcanic center that has had a recent eruption (see, "What is an eruption") or period of intense deformation, seismic or fumarolic activity that is inferred to reflect the presence of magma at shallow levels within the volcano. The "historical" period in Alaska is now considered to be after 1741, when written records of volcanic activity began. On the basis of a rigorous re-analysis of all accounts of volcanic activity in Alaska from many sources, Cameron and others (2018) concluded that 54 Alaskan volcanoes fit these criteria. This is a change from the often-cited 41 volcanoes of Miller and others (1998), and from previously published map compilations. As geologic understanding of Alaska's volcanoes improves through additional fieldwork and modern radiometric-dating techniques, our list of "active" volcanoes will continue to evolve. minimum number of local seismograph stations to locate earthquakes. Little Sitkin and Semisopochnoi Islands are not considered monitored because the telemetry continues to be unreliable. Mount Wrangell and Fourpeaked Mountain volcanoes are not considered seismically monitored owing to network-wide outages that continued throughout 2017.

\section{Volcanic Activity in Alaska}

Volcano descriptions are presented in geographic order from northeast to southwest along the Aleutian Arc. Each entry has a title block with information about the volcano - unique identifier assigned by the Smithsonian Institution Global Volcanism Program (GVP); latitude, longitude, and summit elevation; its geographical region; and an abbreviated summary of the 2017 activity. Each summary is followed by detailed activity information, often with accompanying tables, images, and (or) figures, ending with a description of the volcano and summary of past volcanic activity. The event summary is derived from published material such as Miller and others (1998) and the Smithsonian Institution Global Volcanism Network Bulletin (available at htpp:/www.volcano.si.edu/ reports_bgvn.cfn) as well as AVO daily status reports, AVO weekly updates, information releases, AVO email and online electronic logs. Beginning with the 2013 report, AVO's annual summary includes expanded information on seismicity at Alaska volcanoes. Volcanic activities in past and present AVO summaries are compiled by year (table 2.1) and by volcano (table 2.2).

Measurements are presented in International System of Units (SI) with approximate conversions to English or inchpound units in parentheses for convenience. Altitudes and elevations reported are in meters $(\mathrm{m})$ and feet $(\mathrm{ft})$ above sea level (ASL). Time is reported as Coordinated Universal Time (UTC) with the local time, Alaska Standard Time (AKST) or Alaska Daylight Time (AKDT) in parentheses. Volcano locations in latitude and longitude, in decimal degrees, and summit elevations, in meters and feet, are taken from the AVO database and may differ slightly from previously published compilations. 
Table 4. History of seismic monitoring of Alaska volcanoes from August 1971 through December 2017.

[First station installed refers to the date when the Alaska Volcano Observatory (AVO) first received real-time data from a permanent station. This date can be many months after initial fieldwork at the volcano. AVO considers the seismic network "complete" (bolded date) after installation and data transmission from a minimum of four seismic stations. Typically, AVO seismologists monitor the seismicity at the volcanic center for at least 6 months to understand background rates of seismicity before formally declaring a volcano seismically monitored and adding it to the monitored list. The number of stations in parenthesis is the number of installed seismograph stations at the end of 2017. We note here the first mention and range of time, when applicable, of the seismic status of each monitored volcano in the AVO weekly update. The AVO weekly update has been regularly issued since the Redoubt Volcano eruption in 1989-90. The magnitude of completeness is the lowest magnitude earthquake that can confidently be located for activity at the volcanic center with an operational seismograph network. For more information on specific seismic network histories, readers are referred to the series of annual seismic summaries prepared by AVO (for example, Dixon and others, 2019). N/A, not applicable]

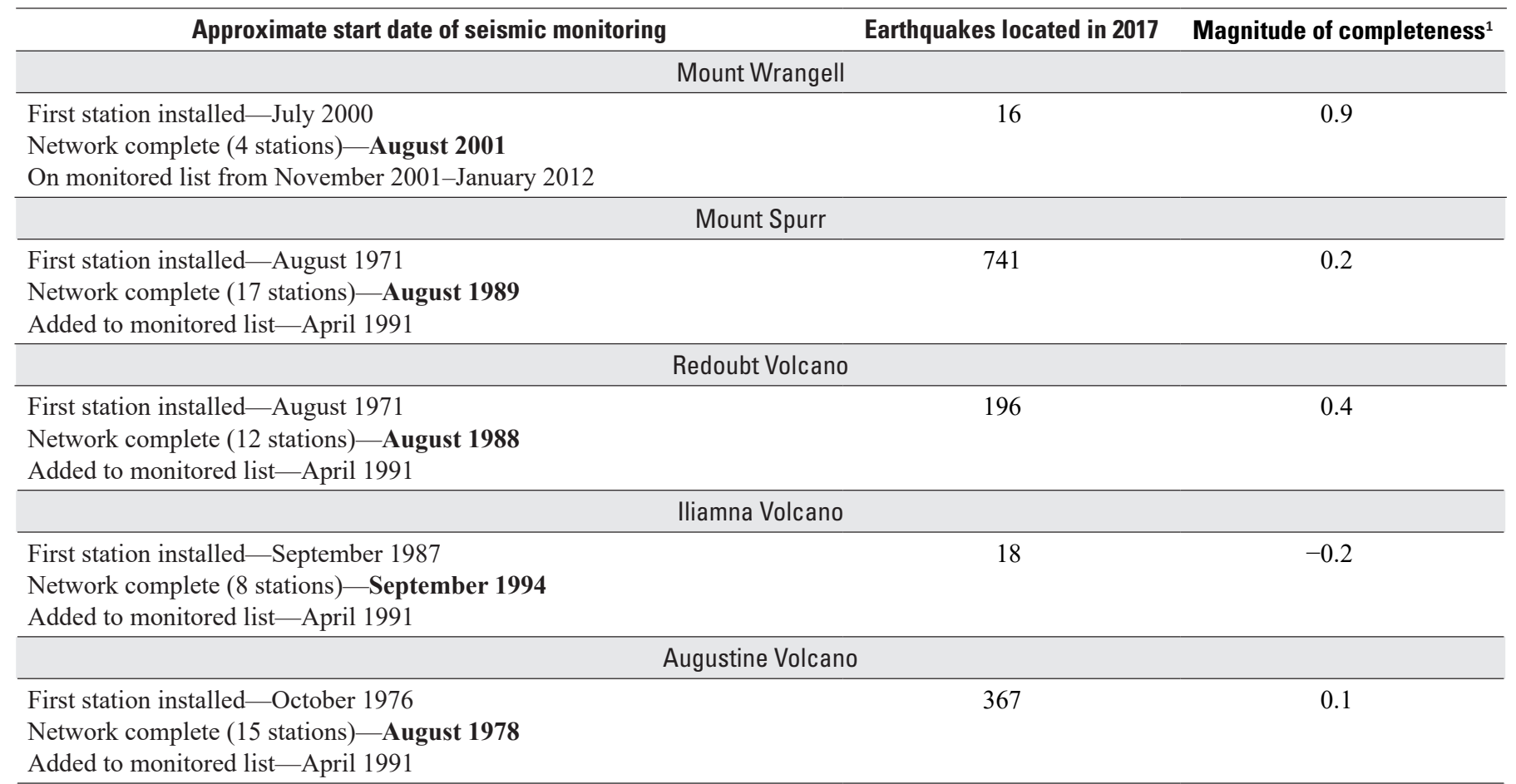

\begin{tabular}{lcc}
\hline \multicolumn{1}{c}{ Fourpeaked Mountains } & \\
\hline First station installed-September 2006 & 33 \\
Network complete (4 stations)-October 2006 & \\
On monitored list-October 2006-November 2009; October 2011-February \\
$\quad 2014$
\end{tabular}

\begin{tabular}{|c|c|c|}
\hline \multicolumn{3}{|c|}{ North Katmai area (Snowy Mountain) } \\
\hline $\begin{array}{l}\text { First station installed-August } 1988 \\
\text { Network complete (5 stations)-October } 1998 \\
\text { Added to monitored list_-December } 1998\end{array}$ & 138 & 0.8 \\
\hline \multicolumn{3}{|c|}{ Central Katmai area (Mount Griggs, Mount Katmai, Novarupta, and Trident Volcano) } \\
\hline $\begin{array}{l}\text { First station installed-August } 1988 \\
\text { Network complete ( } 8 \text { stations)-July } 1991 \\
\text { Added to monitored list-November } 1996\end{array}$ & 853 & 0.4 \\
\hline Sout & (lageik) & \\
\hline
\end{tabular}

First station installed-August 1988

321

Network complete (8 stations) - July 1996

Added to monitored list—November 1996

Ukinrek Maars and Mount Peulik

First station installed-March 2005 7

Network complete (7 stations) - August 2004

Added to monitored list-April 2005 
Table 4.-Continued

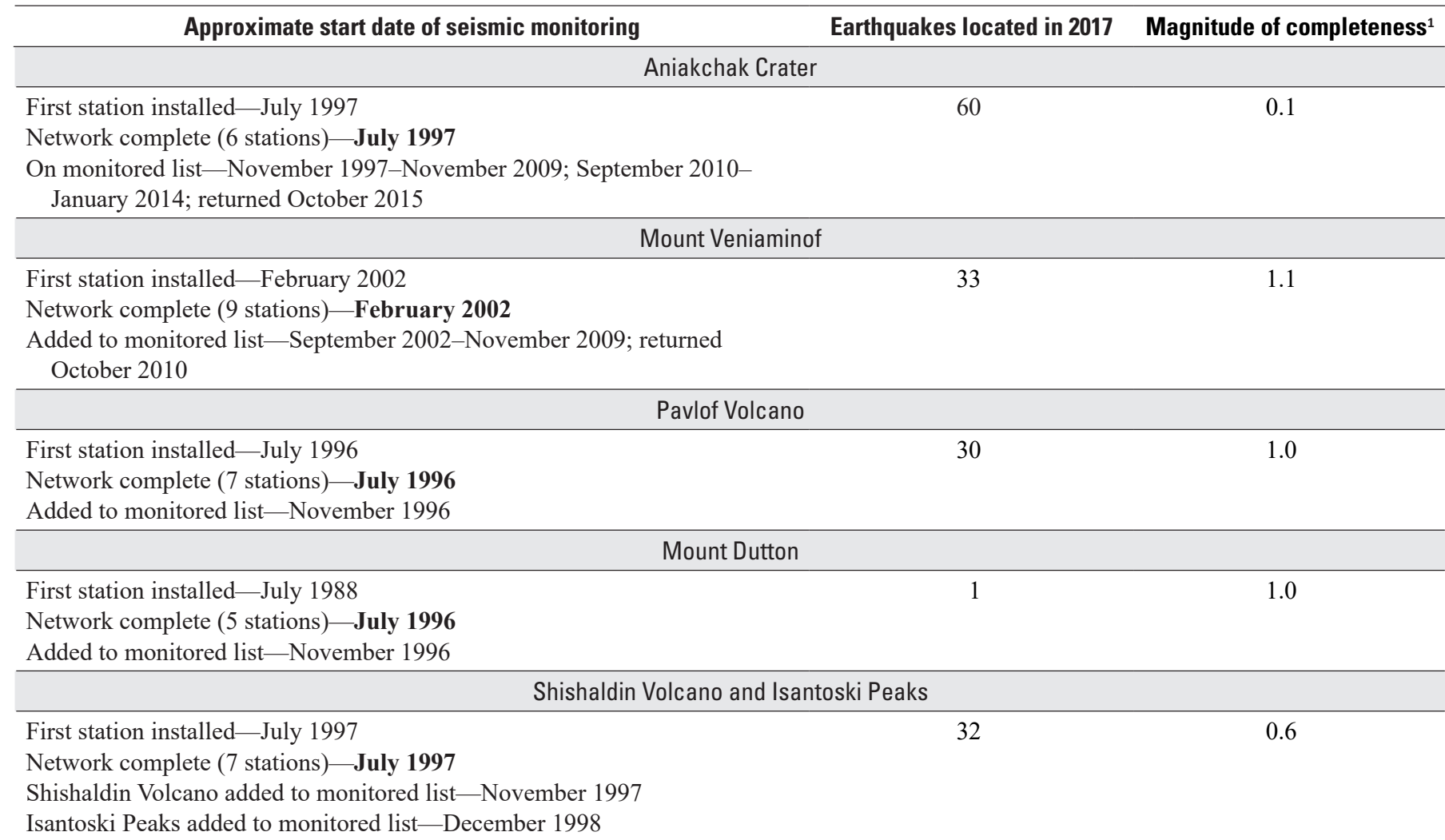

\begin{tabular}{lll}
\hline \multicolumn{2}{l}{ Westdahl Peak and Fisher Caldera } & \\
\hline First station installed-August 1998 & 66 & 1.1 \\
Network complete (6 stations)_October 1998 & & \\
Added to monitored list_-December 1998 &
\end{tabular}

\section{Akutan volcano}

First station installed-March 1996

Network complete (13 stations)_July 1996

Added to monitored list-November 1996

\section{Makushin Volcano}

First station installed-July 1996

Network complete (7 stations) - July 1996

Added to monitored list—November 1996

\section{Okmok volcano}

First station installed-January 2003 32

Network complete (13 stations) - January 2003

Added to monitored list_-January 2004

\begin{tabular}{lll}
\hline & Mount Cleveland & \\
\hline First station installed-August 2014 & & \\
Network complete (2 stations)—N/A & & \\
Has not been added to the monitored list. & Korovin Volcano & \\
\hline & & 114
\end{tabular}

Network complete (7 stations) - July 2004

On monitored list-December 2005-November 2009; October 2010

October 2011; returned March 2014 
Table 4.-Continued

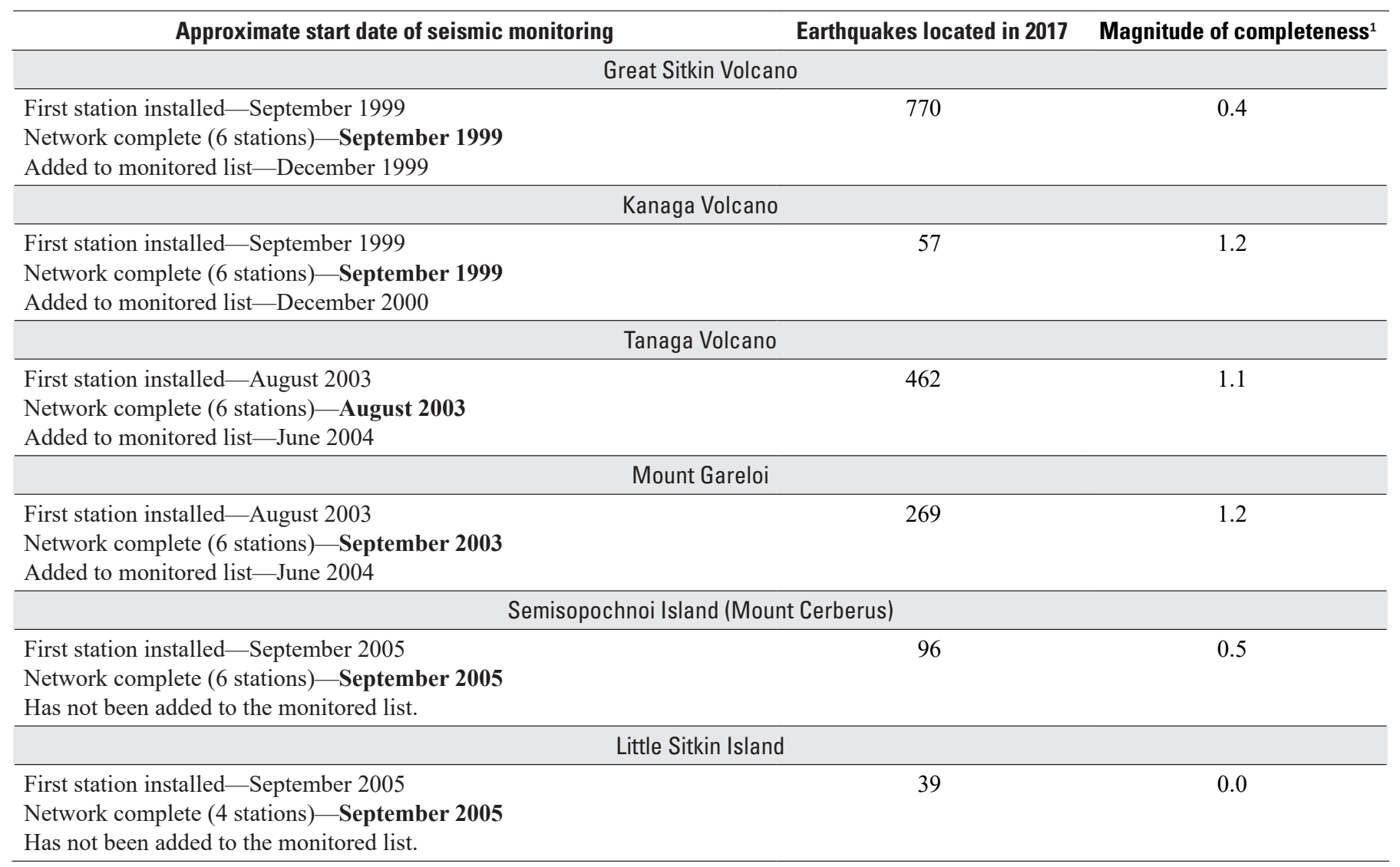

\section{Mount Spurr}

GVP\# 313040

$61.2989^{\circ} \mathrm{N} ., 152.2539^{\circ} \mathrm{W}$.

$3,374 \mathrm{~m}(11,070 \mathrm{ft})$

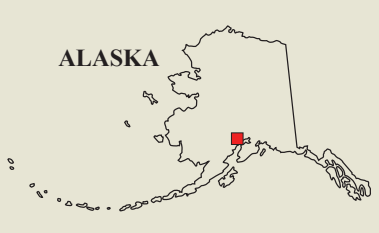

Cook Inlet

\section{EARTHQUAKE SWARM}

No volcanic activity was reported at Mount Spurr in 2016, but five clusters of seismic activity in 2016 continued into 2017 (fig. 2), including an unusual earthquake sequence that started in 2015. AVO refers to Mount Spurr and the surrounding features associated with its volcanism as "Spurr." This cluster of lowfrequency earthquakes (north Spurr earthquakes), was located 12 kilometers $(\mathrm{km} ; 7 \mathrm{mi})$ north of Mount Spurr and continued to show activity throughout 2017. Although the character of the earthquakes is similar to glacial earthquakes, AVO has not determined a definite cause for this cluster of seismicity. The other four clusters (Mount Spurr summit, south Spurr, west Spurr, and the Strandline Lake earthquakes) are typical seismicity seen year-round in the vicinity of Mount Spurr (fig 2). An April 20 gas observation flight noted that the small plume emanating from the fumaroles in Spurr's summit crater contained detectable quantities of $\mathrm{SO}_{2}, \mathrm{H}_{2} \mathrm{~S}$, and $\mathrm{HCl}$. The Aviation Color Code and Volcano Alert Level remained at GREEN and NORMAL throughout the year at Mount Spurr.

Mount Spurr is a 3,374 $\mathrm{m}$ high $(11,070 \mathrm{ft})$ stratovolcano located $125 \mathrm{~km}$ (80 mi) west of Anchorage (fig. 3). Explosive historical eruptions occurred in 1953 and 1992 from Crater Peak, a satellite vent $3.5 \mathrm{~km}$ ( $2 \mathrm{mi}$ ) south of Mount Spurr's summit (Keith, 1995). Each of these eruptive phases produced ash falls on populated areas in south-central Alaska. The summit of Mount Spurr is a primarily ice-covered feature previously interpreted as a lava dome complex (Nye and Turner, 1990). Multiple prehistoric (before 1700) eruptions at Mount Spurr have been identified (Riehle, 1985; Waythomas and Nye, 2002; Waythomas, 2007). 


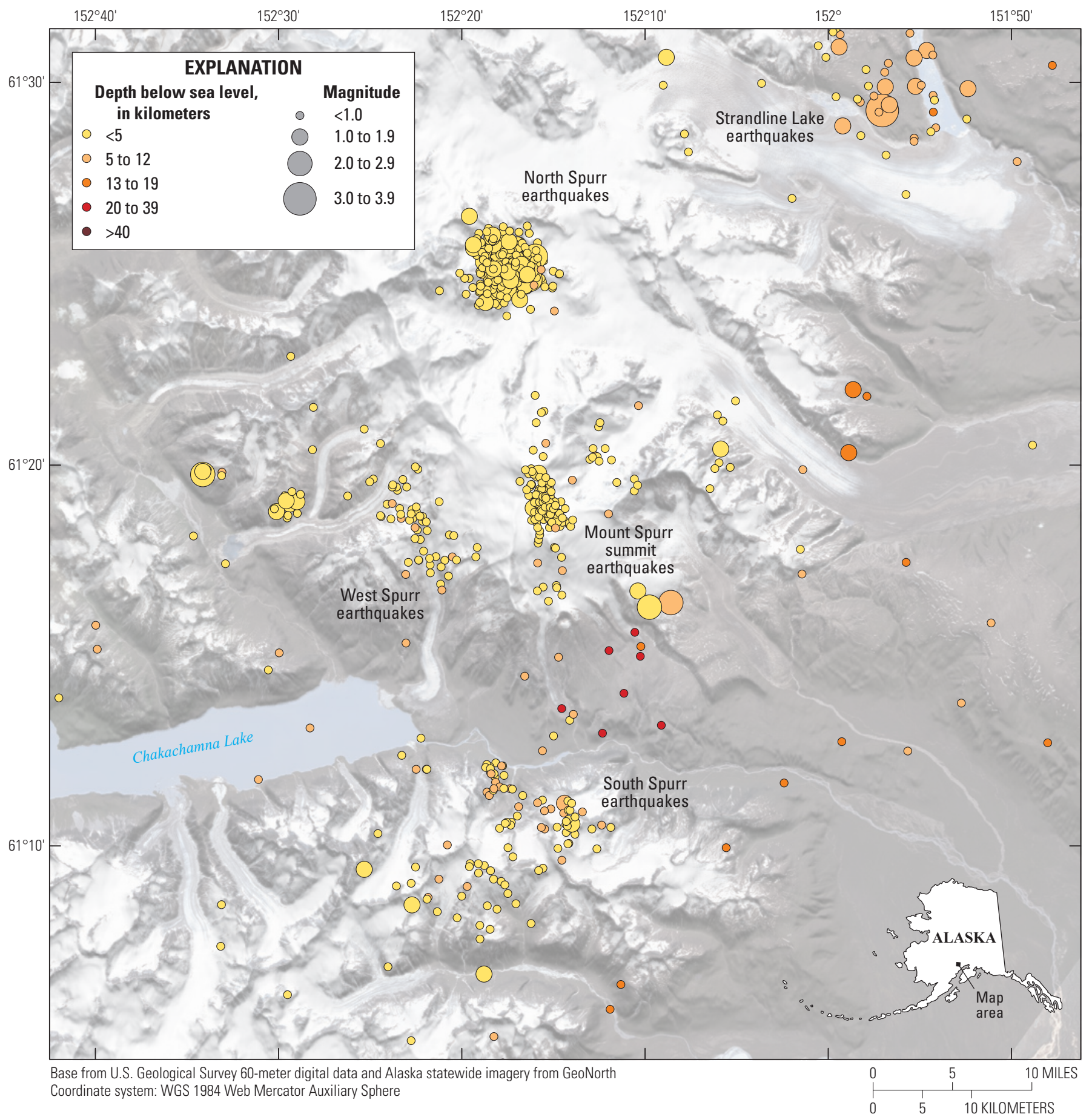

Figure 2. Epicentral map showing clusters of seismicity near Mount Spurr in 2017. The four clusters of distinct seismicity are the Mount Spurr summit earthquakes, north Spurr earthquakes, west Spurr earthquakes, south Spurr earthquakes, and the Strandline Lake earthquakes. 


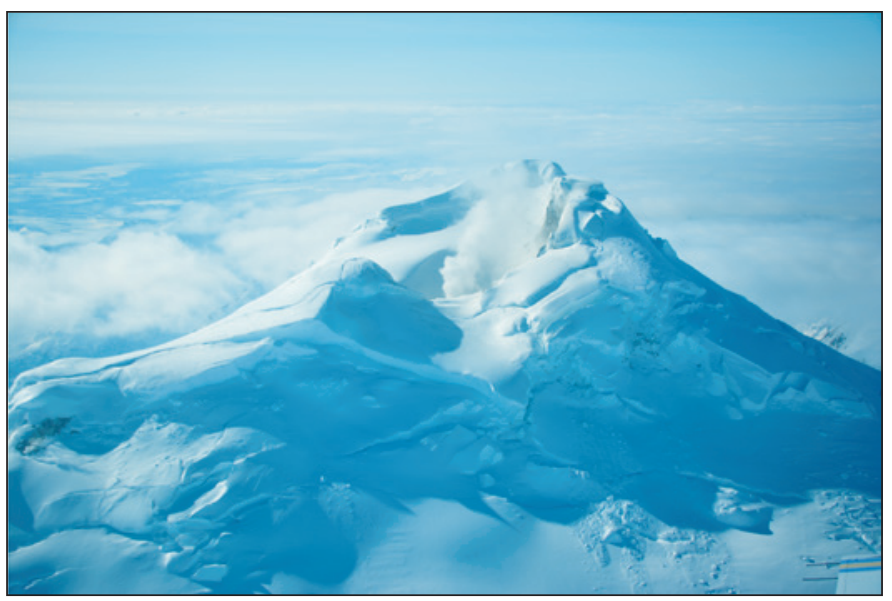

Figure 3. Aerial photograph of the summit of Mount Spurr on April 20, 2017. Photograph by Taryn Lopez, University of Alaska Fairbanks Geophysical Institute and Alaska Volcano Observatory.

\section{Redoubt Volcano}

GVP\# 313030

$60.4852^{\circ}$ N., $152.7438^{\circ} \mathrm{W}$.

$3,108 \mathrm{~m}(10,197 \mathrm{ft})$

Cook Inlet

\section{GAS PLUME}

AVO received a citizen observation of degassing from Redoubt Volcano on April 26, 2017. The report was of a heavy plume and (or) eruption, but checks of multiple datasets showed no anomalous activity. Meteorological conditions were favorable to accentuate on-going gas emission from the cooling 2009 lava dome, and thus no other action was taken by observatory personnel.

On April 20, 2017, a few days before the report of steaming, an observation and gas overflight by AVO observed a condensed plume that was emanating from the south end of the crater dome, and all gas species $\left(\mathrm{SO}_{2}, \mathrm{H}_{2} \mathrm{~S}, \mathrm{HCl}\right.$, and $\mathrm{CO}_{2}$ ) were detected. The observations of the plume and its composition are consistent with expected background degassing. The Aviation Color Code and Volcano Alert Level remained at GREEN and NORMAL, respectively, throughout the year.

Heavily ice-mantled Redoubt Volcano is located on the west side of Cook Inlet, $170 \mathrm{~km}$ (106 mi) southwest of Anchorage and $82 \mathrm{~km}(51 \mathrm{mi})$ west of Kenai, Alaska, within Lake Clark National Park and Preserve (fig. 4). Historical eruptions occurred in 1902, 1966-68,

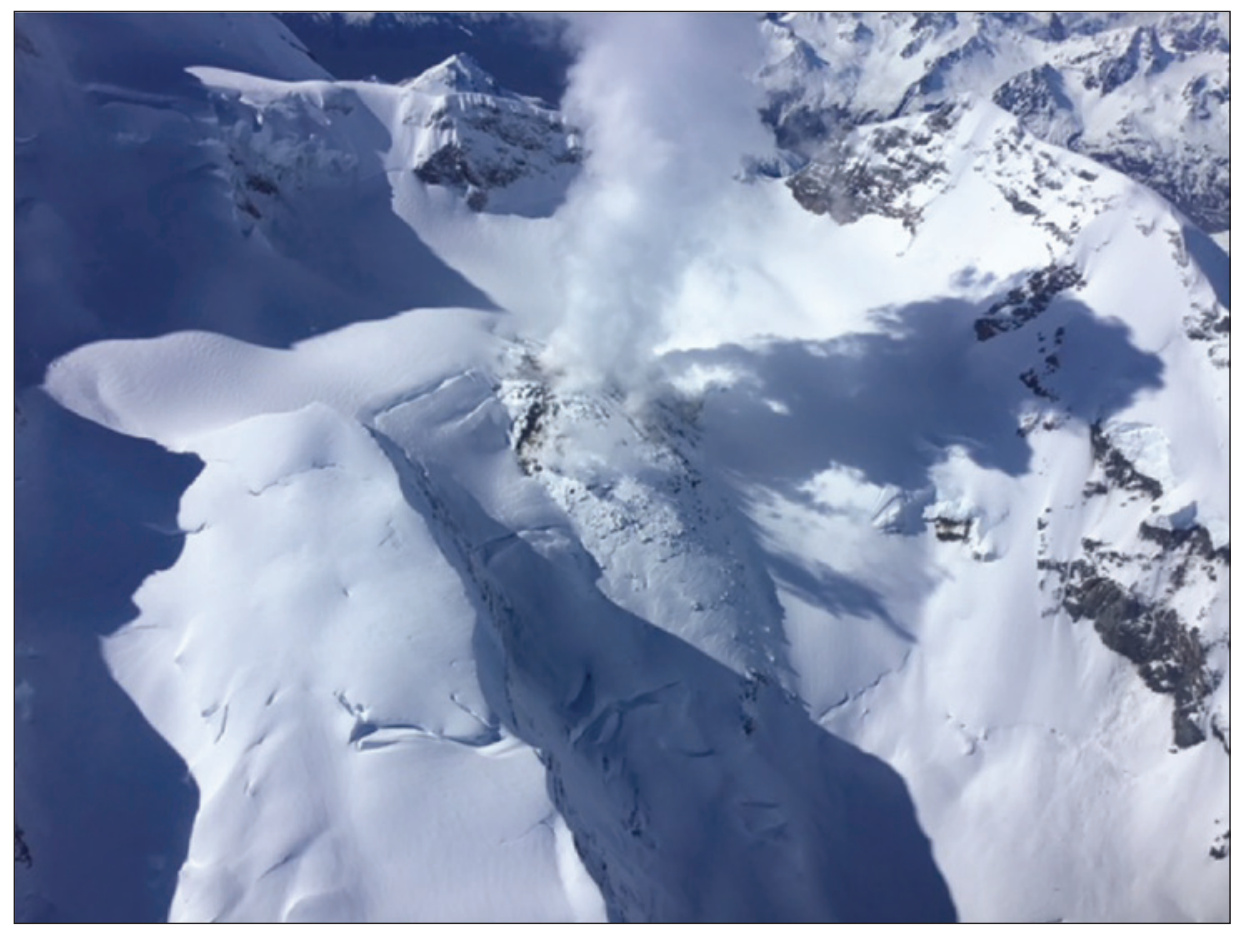
1989-90, and 2009 (Waythomas and others, 1997; Schaefer, 2011; Bull and Buurman, 2013). The 1989-90 and 2009 eruptions produced mudflows that traveled down the Drift River drainage and partially flooded the Drift River Oil Terminal facility. The 1966-68 eruption also produced lahars that flowed down the Drift River drainage. Ash clouds produced by the 1989-90 and 2009 eruptions affected air traffic and resulted in minor or trace amounts of ash on communities in south-central Alaska (Miller and Chouet, 1994; Schaefer, 2011).

Figure 4. Aerial photograph of the 2009 lava dome on Redoubt Volcano on May 27, 2018, as viewed from the northwest. Photograph by Pat Madland. 


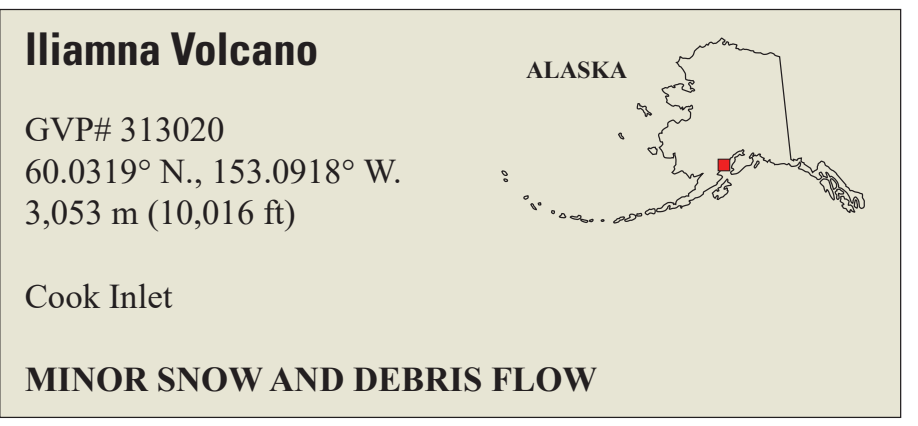

Avalanches are common on Iliamna Volcano, and although no large debris avalanches were noted in 2017, small debris flows were observed. In March, a pilot noticed a debris flow feature on the west side of Iliamna Volcano (fig. 5). A second flow feature was fortuitously imaged by an AVO web camera in mid-April. A review of web-camera images shows the debris flow began on April 12 during the warmest part of the day, with more material moving downslope over a period of 6 hours (fig. 6). During an April 20 gas overflight, AVO observed minor snow and debris avalanche deposits on all flanks of the volcano. Despite complications from a south wind, successful gas measurements were obtained from

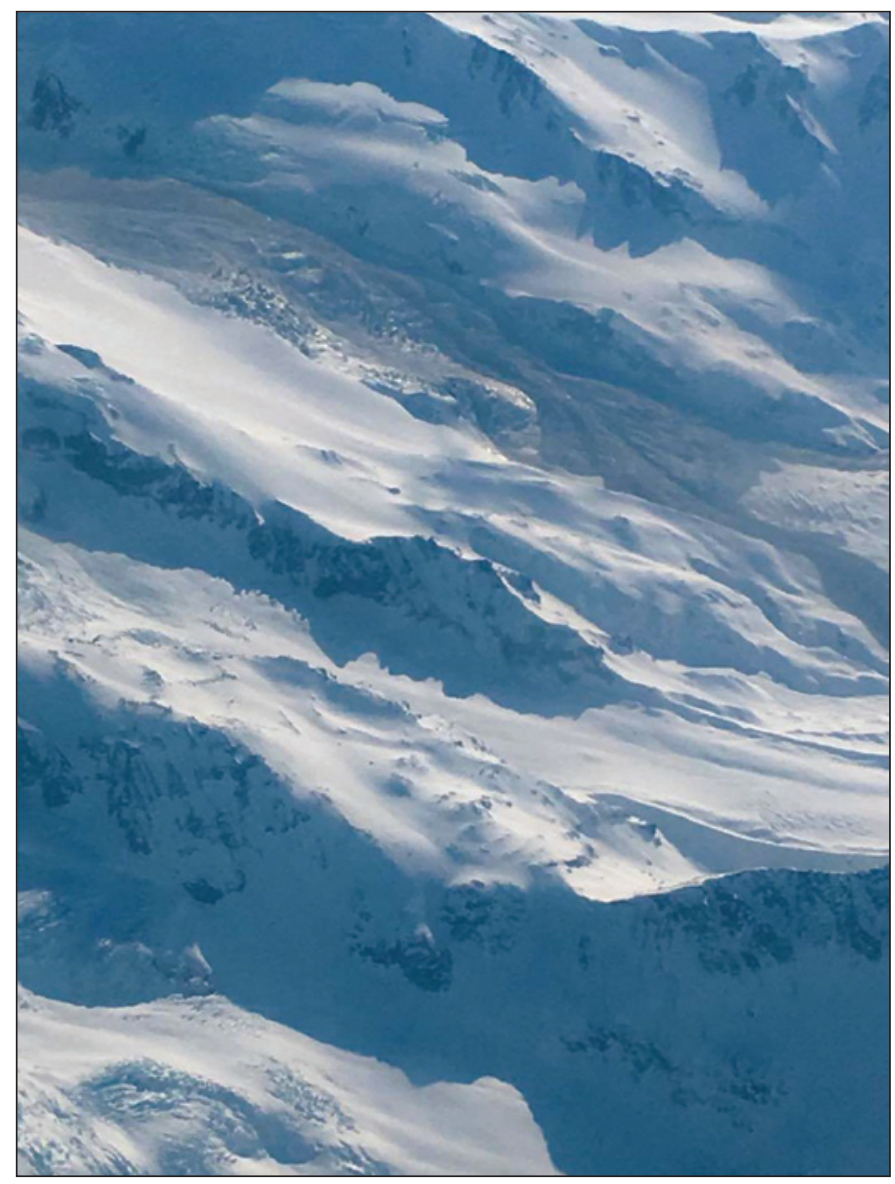

Figure 5. Photograph from March 17, 2017, of a debris flow on the west flank near the summit of lliamna Volcano spotted by a citizen observer. Photograph by Gary Nielsen. the fumarole fields on the southeast side of the volcano indicating typical background-level emissions. The Aviation Color Code and Volcano Alert Level at Iliamna Volcano remained at GREEN and NORMAL, respectively, throughout the year.

Iliamna Volcano is a glacier-carved stratovolcano located approximately $215 \mathrm{~km}$ (134 mi) southwest of Anchorage on the west side of lower Cook Inlet. Although no historical eruptions are known, geologic studies document late Holocene explosive activity as well as repeated, significant mass wasting of the steep, hydrothermally altered edifice (Waythomas and Miller, 1999). Fumaroles located at about 2,740 $\mathrm{m}(8,990 \mathrm{ft})$ on the east flank (fig. 7) produce nearly constant plumes of steam and volcanic gas (Werner and others, 2011). In the past two decades, at least two magmatic intrusions without an eruption have occurred (Roman and others, 2004; Prejean and others, 2012).

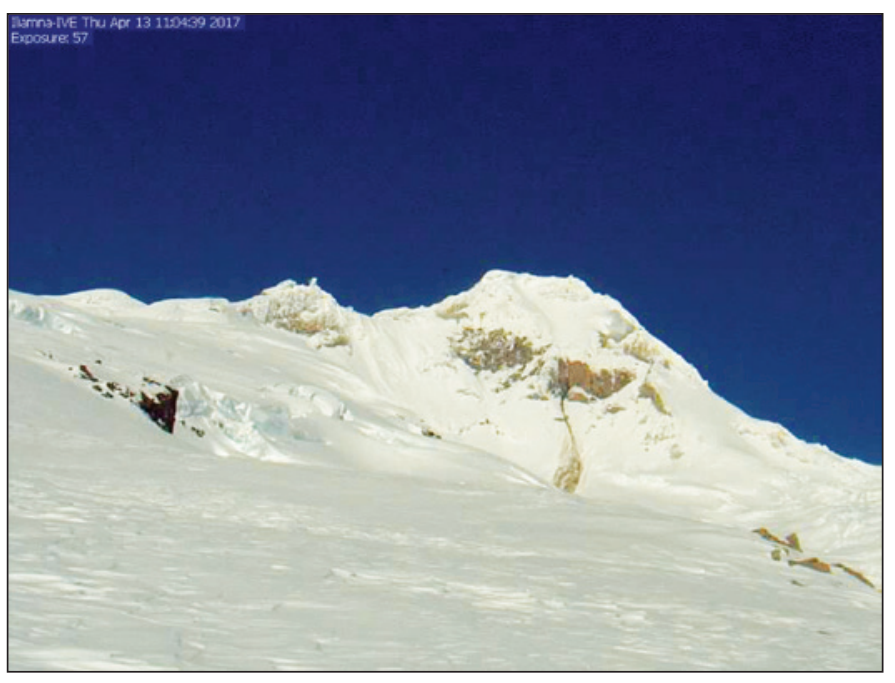

Figure 6. Alaska Volcano Observatory web-camera image from April 13, 2017, of a debris flow on the east side of lliamna Volcano.

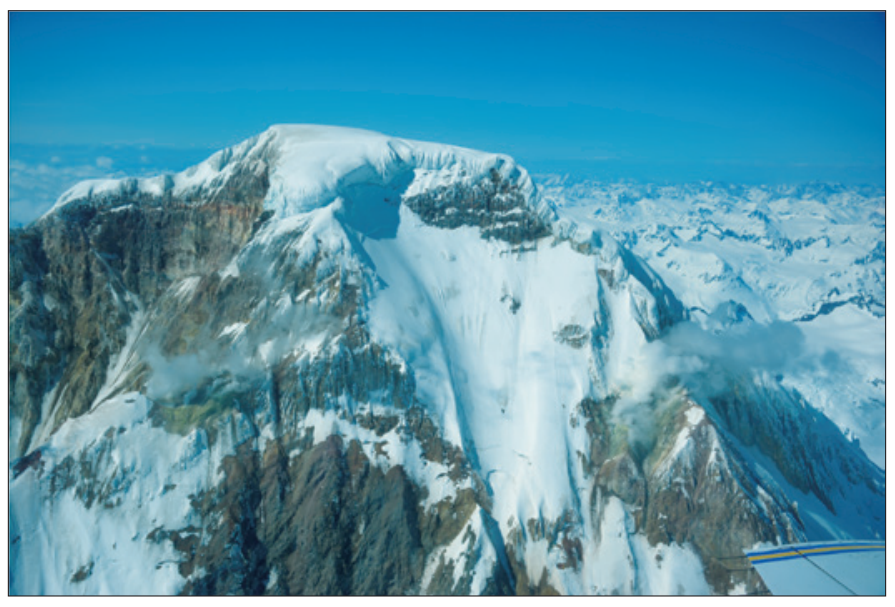

Figure 7. Aerial photograph of degassing from the two main fumarole fields on the east flank of lliamna Volcano on April 20, 2017. Photograph by Taryn Lopez, University of Alaska Fairbanks Geophysical Institute and Alaska Volcano Observatory. 


\section{Augustine Volcano}

GVP\# 313010

$59.3626^{\circ} \mathrm{N} ., 153.4350^{\circ} \mathrm{W}$. $1,260 \mathrm{~m}(4,134 \mathrm{ft})$

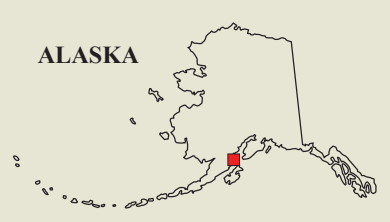

Cook Inlet

\section{SEISMIC ACTIVITY}

The number of earthquakes located at Augustine Volcano in 2017 was abnormally high but was less than half (367) the number located in the previous year (836). The high level of seismicity was monitored closely and was determined not indicative of a pending eruption. A gas overflight in April was unable to make measurements of the plume, but on-ground measurements in July indicated that degassing activity remained at low levels. The Aviation Color Code and Volcano Alert Level at Augustine Volcano remained at GREEN and NORMAL, respectively, throughout the year.

Augustine Volcano, which forms the bulk of the $8 \times 11 \mathrm{~km}$ $(5 \times 7 \mathrm{mi})$ Augustine Island in lower Cook Inlet, is one of the most visible and accessible volcanoes in Alaska (fig. 8). Augustine Volcano consists of a conical, central dome cluster and lava flow complex surrounded by a more gently sloping apron of fragmental deposits. Repeated sector collapses during the late Holocene have produced debris avalanches into Cook Inlet (Begét and Kienle, 1992), which makes Augustine Volcano a tsunami hazard to communities in south-central Alaska. Historical eruptions include significant activity in 1883, 1885, 1963-64, 1976, 1986, and 2005-06.

\section{Katmai Group (Novarupta)}

GVP\# 312180

$58.2654^{\circ} \mathrm{N} ., 155.1591^{\circ} \mathrm{W}$.

$841 \mathrm{~m}(2,759 \mathrm{ft})$

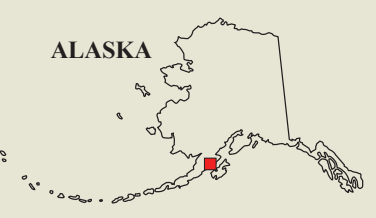

Alaska Peninsula

\section{RESUSPENSION OF 1912 ASH}

Resuspension and transport of fine-grained volcanic ash deposited during the 1912 Novarupta-Katmai eruption has been frequently observed and documented over the last several decades (Hadley and others, 2004; McGimsey and others, 2005). When the landscape is snow-free, particularly when the ground has little moisture content, strong winds can pick up loose ash and create clouds of resuspended ash. These dust clouds are commonly identified as originating broadly from the Mount Katmai area rather than from a specific volcanic source and look similar to dispersing volcanic ash clouds in satellite imagery. Ash resuspension was observed once in early June and twice in November. In response AVO issued Information Statements for two of the three events corroborating formal hazard notifications issued by the National Weather Service (NWS). The Aviation Color Code and Volcano Alert Level remained GREEN and NORMAL, respectively, for all Katmai Group volcanoes during 2017.

On June 4, 2017, a National Oceanic and Atmospheric Administration (NOAA) and National Environmental Satellite, Data, and Information Service ash alert reported a possible resuspension event over the Valley of Ten Thousand Smokes (fig. 9). Atypical, easterly winds carried resuspended ash away

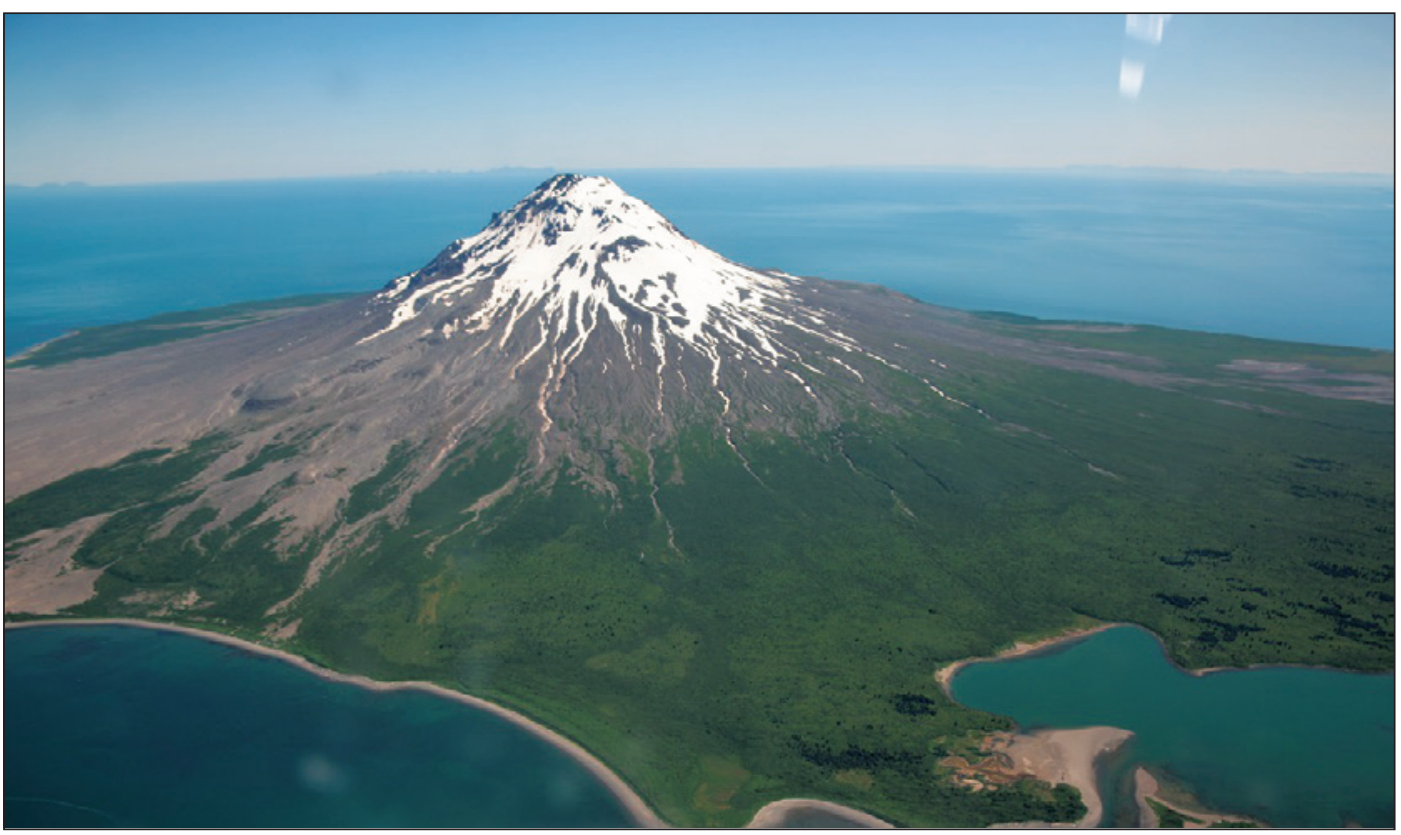

Figure 8. U.S. Geological Survey photograph of Augustine Island and Volcano. Photograph by Michelle Coombs on June 15, 2016. 
A

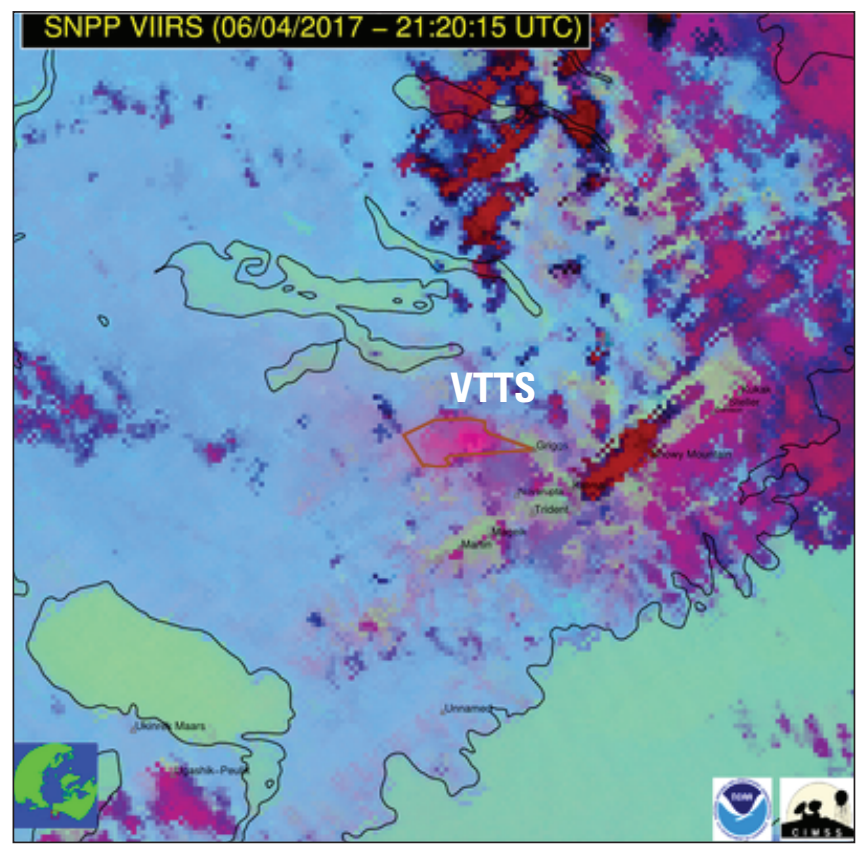

EXPLANATION

Ash/Dust cloud
Thermal anomaly

C

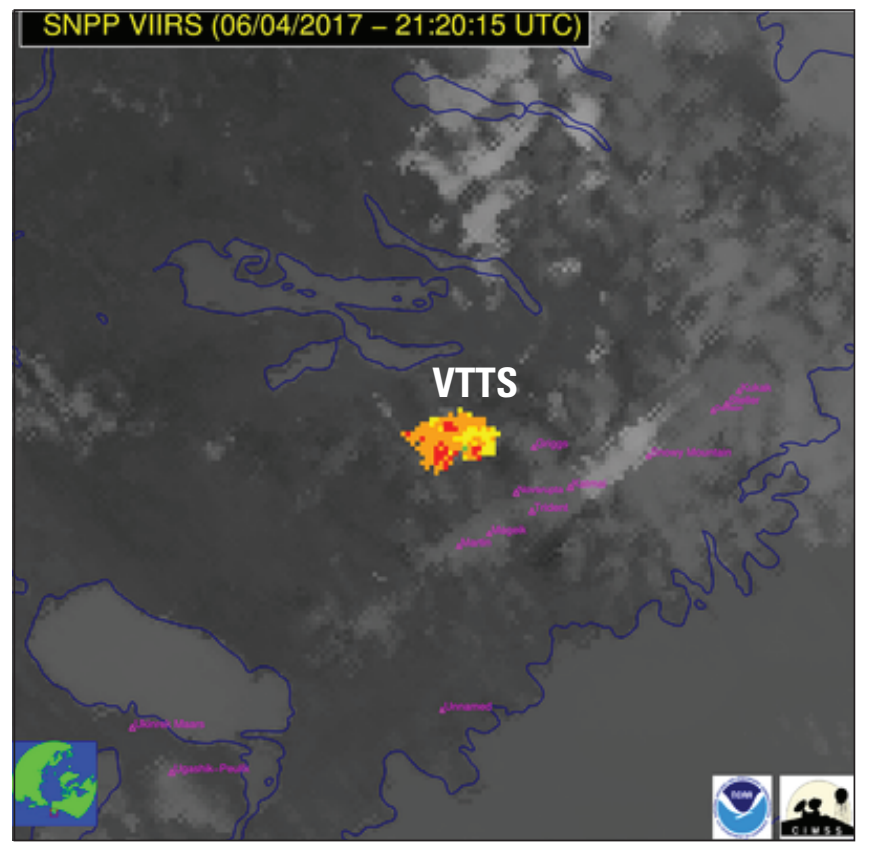

EXPLANATION

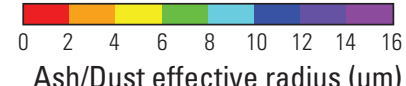

B

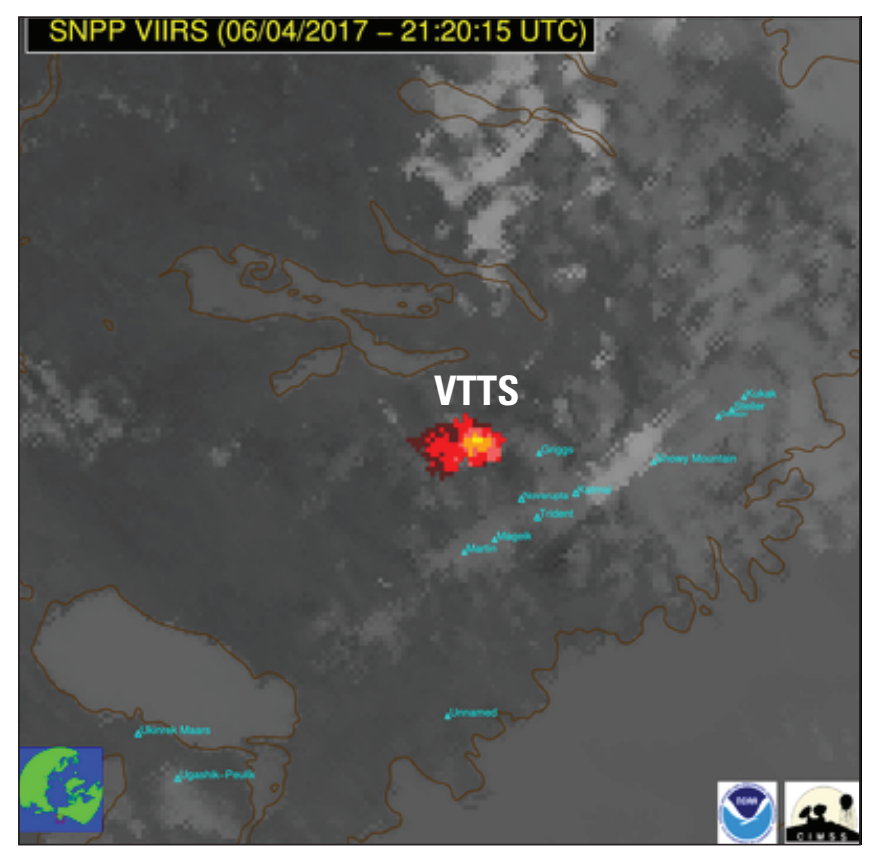

EXPLANATION

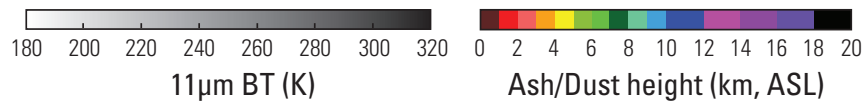

D

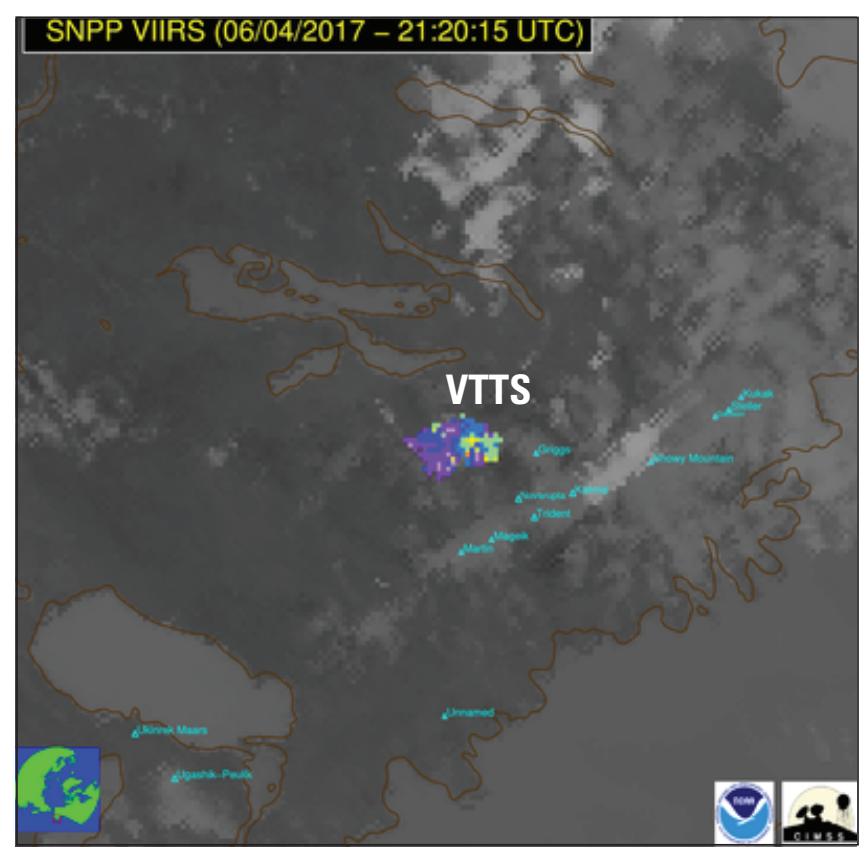

EXPLANATION

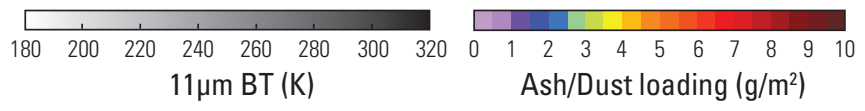

Figure 9. False color satellite images of June 4, 2017, ash resuspension event. $A$, False color satellite image (12-11 micrometers [ $\mu \mathrm{m}$ ], 11-3.9 $\mu \mathrm{m}$, and $11 \mu \mathrm{m}$ ) showing the extent of the resuspended ash cloud (brown). $B$, Infrared (IR) Window image showing the ash and (or) dust cloud height in kilometers above sea level (km; ASL) overlain atop brightness temperature (BT) in degrees Kelvin (K). C, IR Window image showing the effective radius of the ash and (or) dust cloud in $\mathrm{mm}$. $D$, IR Window image showing ash and (or) dust Loading in grams per square meters $\left(\mathrm{g} / \mathrm{m}^{2}\right)$. VTTS shows the location of the Valley of Ten Thousand Smokes. 
from population centers so that an AVO Information Statement was not issued. AVO alerted the NWS Alaska Aviation Weather Unit and documented the resuspension event and evaluation in the AVO internal logs.

Two ash resuspension events were detected in November, and the first was identified by a NOAA and Cooperative Institute for Meteorological Satellite Studies ash alert. On November 10, strong northwest winds over the Valley of Ten Thousand Smokes resuspended volcanic ash into a visible cloud and transported it eastward across Shelikof Strait and over Kodiak Island, where it was detected by the AVO particulate monitors at Larson Bay on the west coast of Kodiak Island. A similar sensor in the city of Kodiak, Alaska, on the east coast of Kodiak Island did not record any ash for this episode. AVO issued an Information Statement corroborating the hazard notifications issued by the NWS. By the evening of November 10, the resuspension event started to wane despite the surface winds continuing with gusts up to 20 meters per second ( 66 feet per second). A similar resuspension event occurred on November 13. The resuspended ash cloud extended $120 \mathrm{~km}$ (72 mi) to the southeast over the south end of Kodiak Island where no particulate monitors were installed. (fig. 10). AVO issued another Information Statement after the detection of this resuspension event.

The 1912 Novarupta-Katmai eruption was the largest of the 20th century, and produced about 17 cubic kilometers $\left(\mathrm{km}^{3}\right.$; 4 cubic miles $\left.\left[\mathrm{mi}^{3}\right]\right)$ of ash deposits and $11 \mathrm{~km}^{3}\left(2.6 \mathrm{mi}^{3}\right)$ of pyroclastic material that filled nearby valleys, creating what is known today as the Valley of Ten Thousand Smokes (fig. 11) (Hildreth and Fierstein, 2012). Ash in this valley is as much as $200 \mathrm{~m}(660 \mathrm{ft})$ thick, and the valley remains almost entirely free of vegetation (Hildreth and Fierstein, 2012).

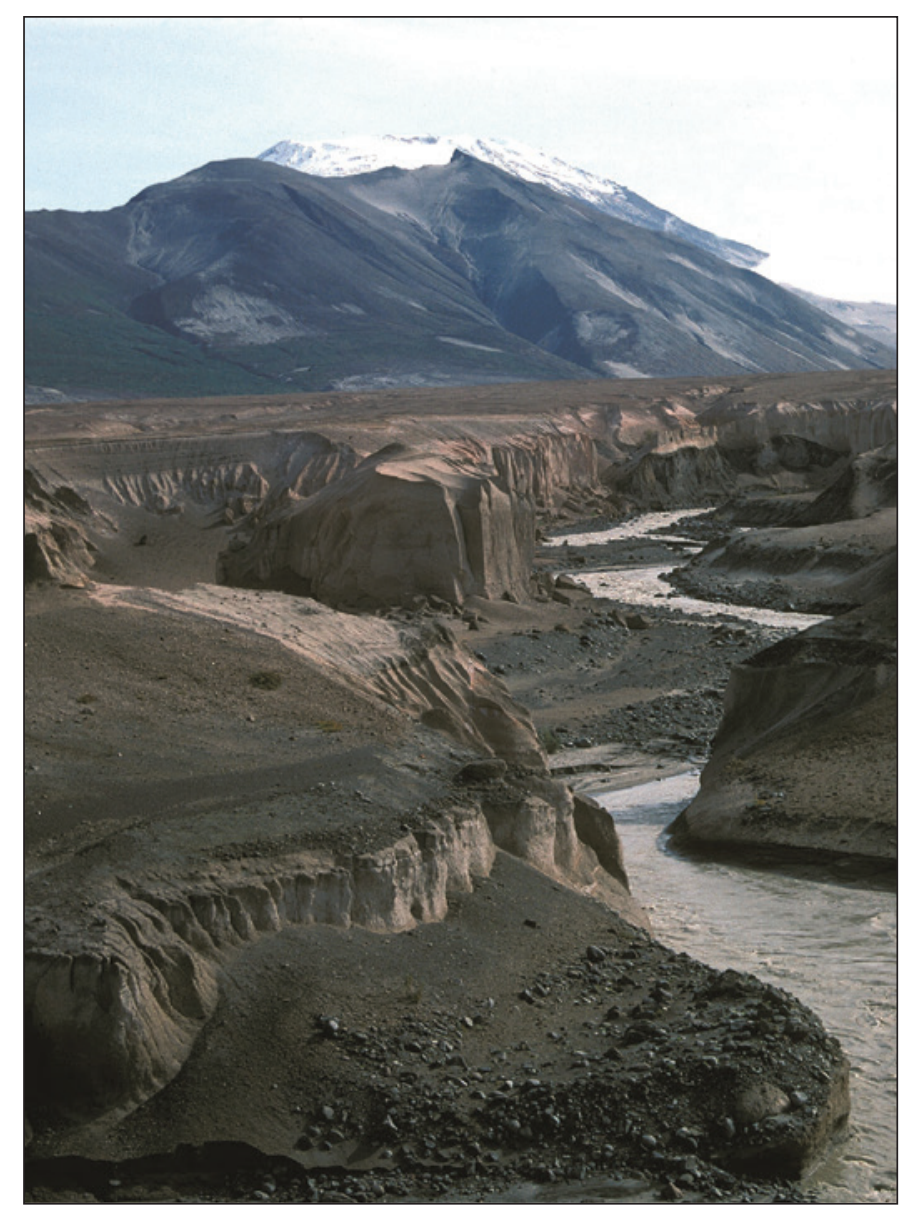

Figure 11. U.S. Geological photograph of River Lethe in Katmai National Park and Preserve, Valley of Ten Thousand Smokes, showing Mount Griggs in the background. The river has cut through the voluminous ash deposit from the 1912 Novarupta-Katmai eruption. Photograph taken by Jennifer Adleman, July 1997.

Figure 10. Satellite image of resuspension event on November 13, 2017. The resuspended ash is visible in the upper right of the image, extending from the Valley of Ten Thousand Smokes (VTTS) eastward to Kodiak Island.

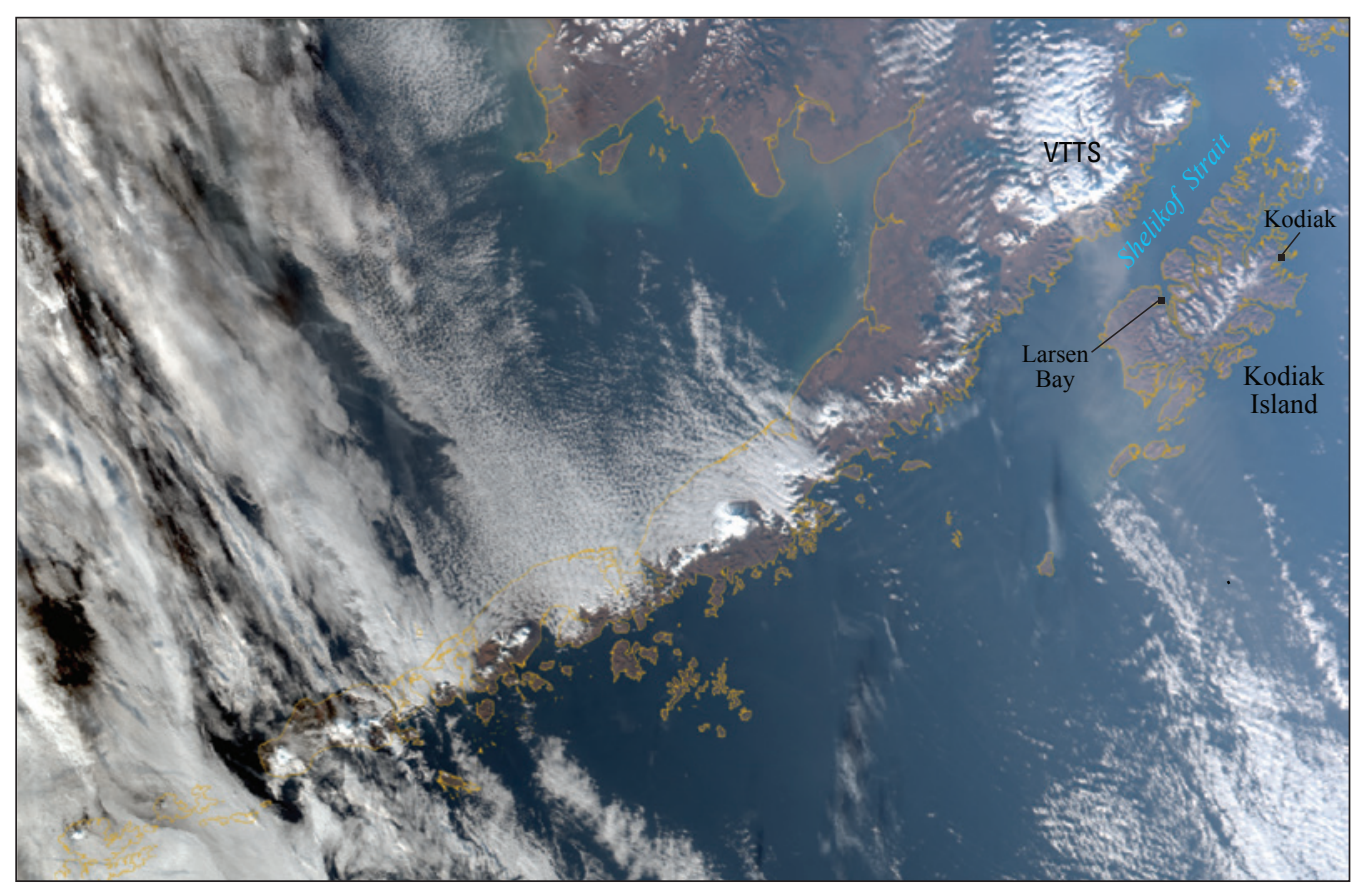




\section{Pavlof Volcano}

GVP\# 312030

$55.4173^{\circ} \mathrm{N} ., 161.8937^{\circ} \mathrm{W}$.

$2,518 \mathrm{~m}(8,261 \mathrm{ft})$

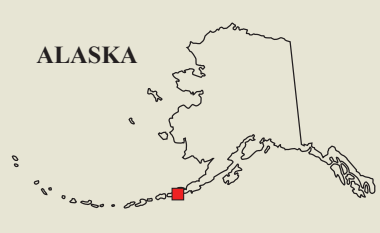

Alaska Peninsula

END OF INTERMITTENT ERUPTION, VOLCANIC

UNREST

Pavlof Volcano started 2017 at Aviation Color Code and Volcano Alert Level YELLOW and ADVISORY, respectively. By February, the level of unrest had returned to background levels with occasional small low-frequency earthquakes continuing to be observed in seismic data, which is consistent with an open degassing system. AVO lowered the Aviation Color Code to GREEN and the Alert Level to NORMAL on February 2, 2017.

Elevated surface temperatures and gas emissions were observed throughout the year. AVO personnel noted weakly elevated surface temperatures on five occasions in FebruaryApril, and at least three robust gas plumes were noted within the same period. AVO observed moderately elevated temperatures on May 10 (fig. 12). On May 28, a pilot report was issued describing a brown plume from Pavlof Volcano that reached an altitude of $3 \mathrm{~km}(10,000 \mathrm{ft})$. Seismic data showed no significant activity coincident with the report of the plume. In the first week of June, a persistent gas plume was observed in clear web-camera and satellite images, prompting increased attention to the Pavlof Volcano data streams. Bursts of strong low-frequency earthquake activity were observed beginning on June 6 . This activity, along with subsequent short-duration tremor bursts and a pilot report of a plume reaching an altitude of $1,200 \mathrm{~m}(4,000 \mathrm{ft})$, AVO raised the Aviation Color Code to YELLOW and the Volcano Alert Level to ADVISORY on June 7.

Multiple observations of elevated surface temperatures and gas plumes were reported following the change in Volcano Alert Level at Pavlof Volcano. Sulfur dioxide $\left(\mathrm{SO}_{2}\right)$ was observed in satellite data on June 8 but was not observed in subsequent satellite imagery. Elevated seismicity declined after two days, and by the end of June 8 seismicity had returned to background levels. Four days later, on June 12 there was a short burst of activity, but no other anomalous seismicity occurred for the remainder of the month. A dark
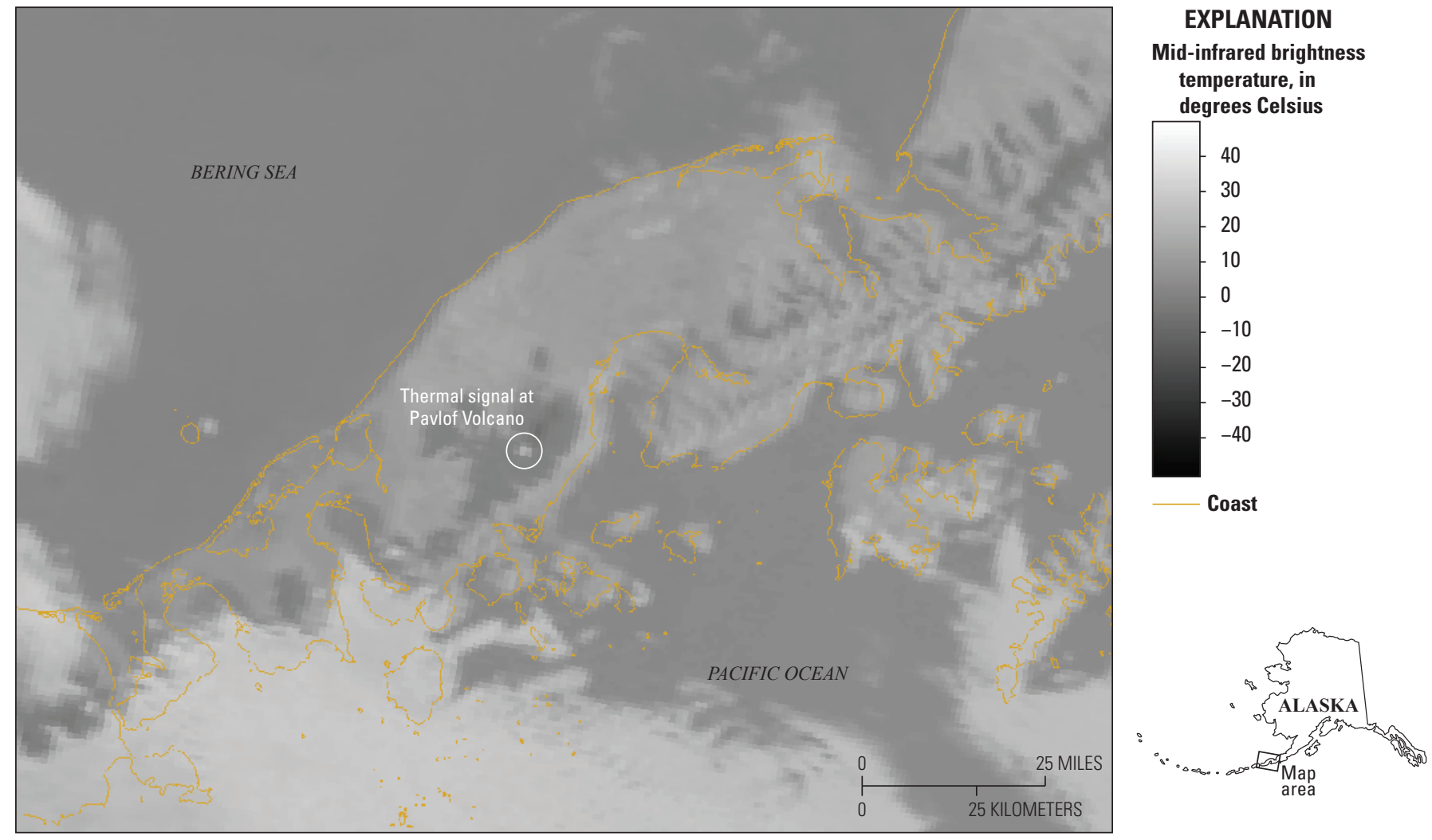

Figure 12. NOAA-18 mid-IR satellite image of moderate surface temperatures at Pavlof Volcano on May 11, 2017, 01:48 UTC (May 10, 2017, 17:48 AKDT). 
grey plume was reported by a pilot on June 22 without any associated seismicity. Infrasound signals were not detected in June.

AVO continued to observe weakly elevated surface temperatures and gas plumes in July and August. Groundbased observations and gas measurements by AVO personnel, obtained on July 17-27, were consistent with degassing of shallow magma. Such degassing would not be detected by seismograph and infrasonic sensors, and only normal background activity was seen on these sensors in July and August. On August 30, in recognition of the decline in activity at Pavlof Volcano since mid-June, AVO reduced the Aviation Color Code to GREEN and the Volcano Alert Level to NORMAL. In the last five months of the year less than a half-dozen observations of suspected unrest were noted. None of these observations prompted a change in the Aviation Color Code and Volcano Alert Level for Pavlof Volcano, which remained at GREEN and NORMAL, respectively.

Pavlof Volcano is a stratovolcano located on the southwest end of the Alaska Peninsula, $950 \mathrm{~km}$ (590 mi) southwest of Anchorage (fig. 13). The first confirmed historical eruption was a Volcanic Explosivity Index 2 (VEI2) eruption in 1817 with 37 total VEI1-VEI3 eruptions noted in the last 200 years, making it the most frequently active volcano in the Aleutian arc (Cameron, 2005). During the previous 10 years there have been eruptive episodes at Pavlof Volcano in 2007, 2013, twice in 2014, and 2016.

\section{Shishaldin Volcano}

GVP\# 311360

$54.7554^{\circ} \mathrm{N} ., 163.9711^{\circ} \mathrm{W}$.

$2,857 \mathrm{~m}(9,373 \mathrm{ft})$

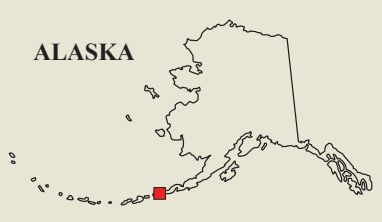

Unimak Islands, Fox Islands, Aleutian Islands

\section{VOLCANIC UNREST}

Shishaldin Volcano did not erupt in 2017, but volcanic unrest in December resulted in an elevated Aviation Color Code and Volcano Alert Level of YELLOW and ADVISORY, respectively, for much of the month. On April 20, AVO received a pilot report of an ash rich plume. Web-camera images confirmed the plume was composed of gas with no evidence of ash. Gas plumes are common at Shishaldin Volcano, and occasional reports of gas plumes and increased low-frequency seismic events were reported in AVO's internal logs for most of 2017.

In the last week of October, AVO noted elevated surface temperatures at the summit of Shishaldin Volcano. Throughout November, AVO observed increased low-frequency seismicity likely to be associated with small explosions. At the end of November, these explosions were being recorded on the infrasound array at Sand Point, Alaska, $230 \mathrm{~km}$ (140 mi) east of the volcano (fig. 14). In response to multiple signs of unrest, AVO

Figure 13. Photograph of Pavlof Volcano (right) on June 14, 2015, with Pavlof Sister (left) and Little Pavlof (right foreground). A large flow feature from the 2014 eruption on the north flank of Pavlof Volcano extends from the summit to the base of the volcano. Photograph by Barbara LaPenter, TetraTech.

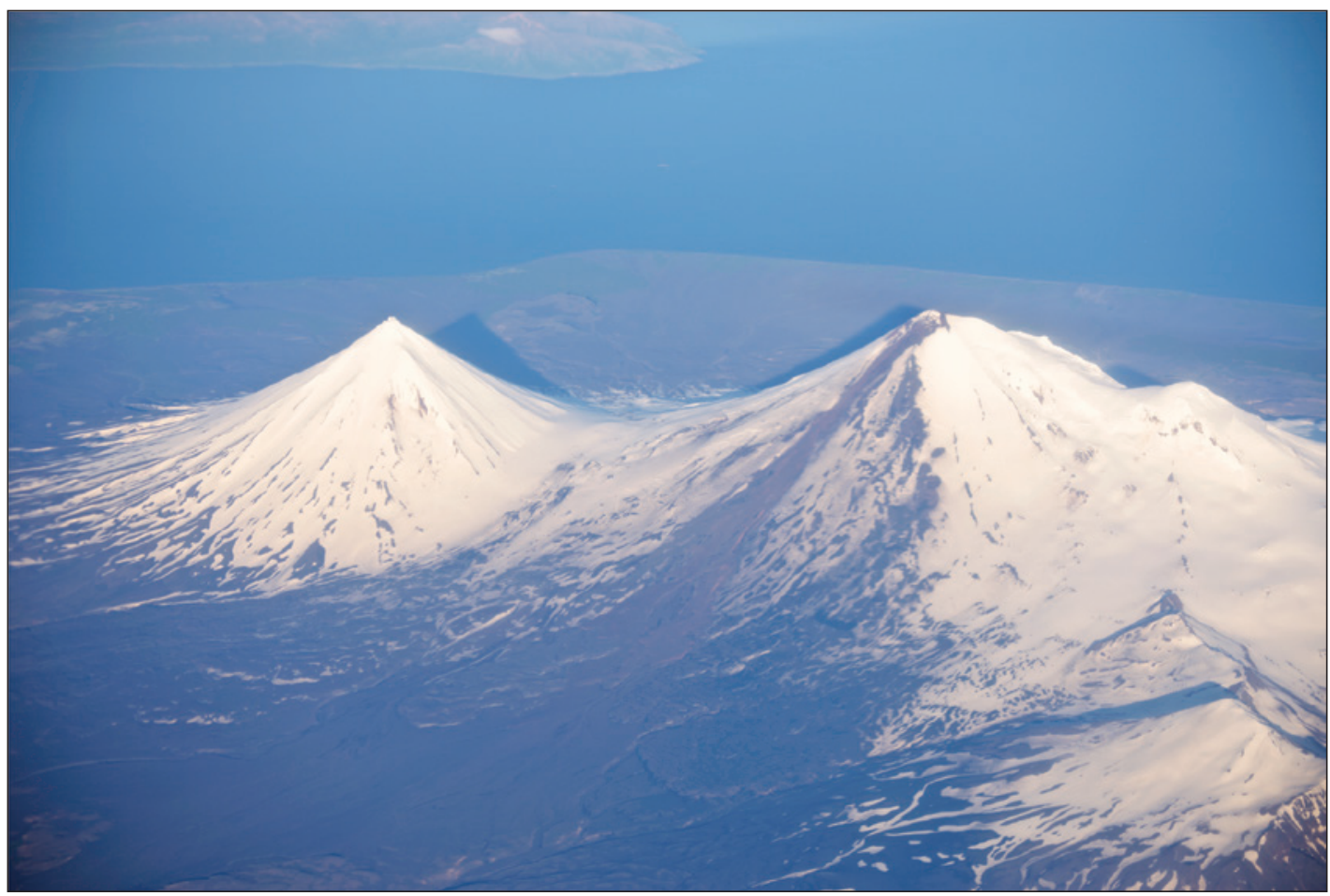



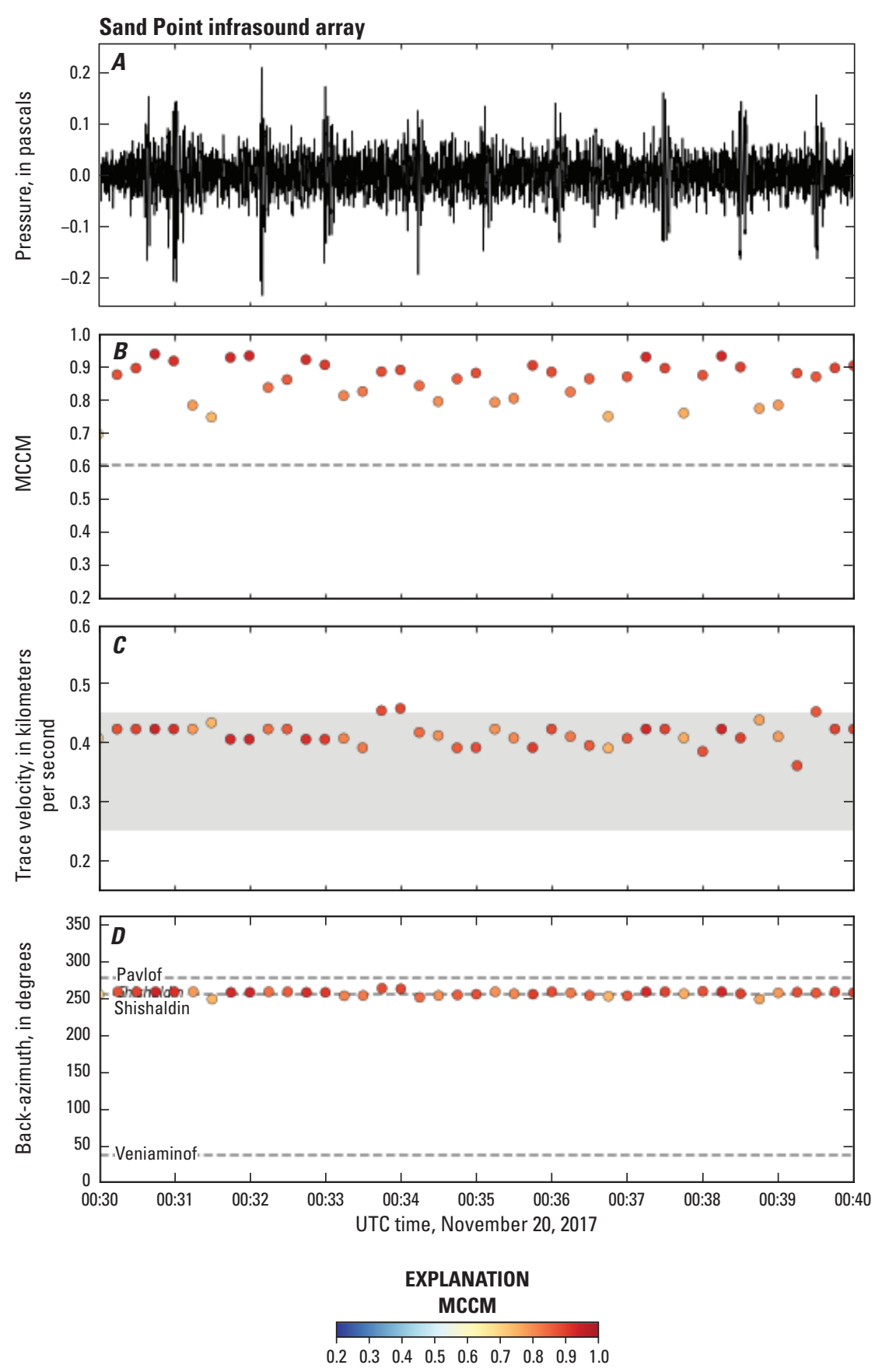

Figure 14. Graphs showing infrasound detection of Shishaldin Volcano on November 30, 2017, observed from the Sand Point, Alaska, infrasound array. $A, A$ simple pressure (in pascals $[\mathrm{Pa}]$ ) plot showing when the explosions occurred. $B$, F-statistic plot, which is an automated way of detecting explosion signals above the noise, the threshold is set at 6 and is indicated by a horizontal dashed line at 0.6 mean cross-correlation maximum (MCCM). F-statistic values are shown by dots shaded with the F-Statistic. C, Plot showing velocity of the signal across the array, in dots shaded with the F-Statistic. D, Plot showing azimuth of the signal with respect to the station. The azimuth is consistently near 250 degrees and is consistent with the location of Shishaldin Volcano. Dots are shown shaded with the F-statistic. Figure modified from image by John Lyons. elevated the Aviation Color Code to YELLOW and Volcano Alert Level to ADVISORY on December 6. Observations of degassing and energetic small explosions continued through December.

Shishaldin Volcano, located near the center of Unimak Island in the eastern Aleutian Islands, is a spectacular symmetric cone with a base diameter of approximately $16 \mathrm{~km}$ (10 mi; fig. 15). A small summit crater typically emits a noticeable gas plume, occasionally with minor amounts of ash. Shishaldin is one of the most active volcanoes in the Aleutian volcanic arc (Cameron, 2005).

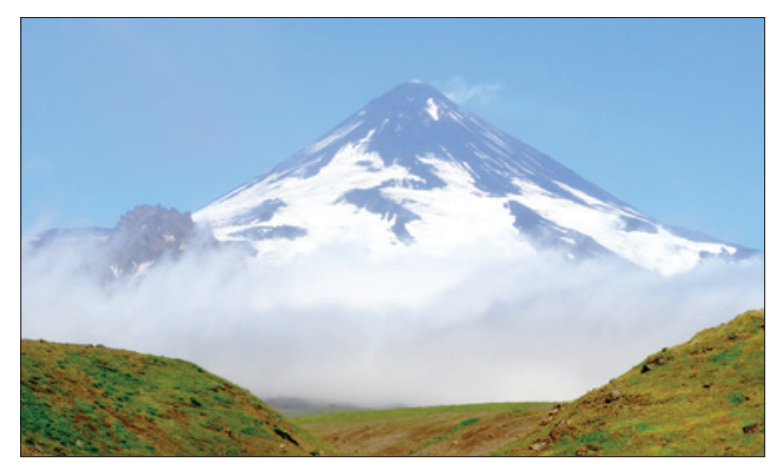

Figure 15. U.S. Geological Survey photograph of Shishaldin Volcano taken on August 7, 2018, by Matt Loewen.

\section{Akutan Peak}

GVP\# 311320

$54.1331^{\circ} \mathrm{N} ., 165.9855^{\circ} \mathrm{W}$. $1,303 \mathrm{~m}(4,275 \mathrm{ft})$

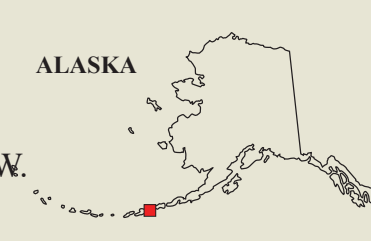

Akutan Island, Fox Islands, Aleutian Islands

\section{EARTHQUAKE SWARM}

From November 11 to November 13, a short earthquake swarm comprising three dozen earthquakes occurred off the coast of Akutan Island, approximately $12 \mathrm{~km}$ (7 mi) northwest of Akutan Peak (herein called Akutan volcano to include the volcano and its surrounding features beyond Akutan Peak; fig. 16). The swarm formed an elliptical cluster with the long axis pointed toward the volcano and dipping approximately 30 degrees down to the southeast. Earthquakes in the beginning of the sequence were located on the northwest end of Akutan Island, and later earthquakes migrated to the southeast. The magnitudes were small and were 


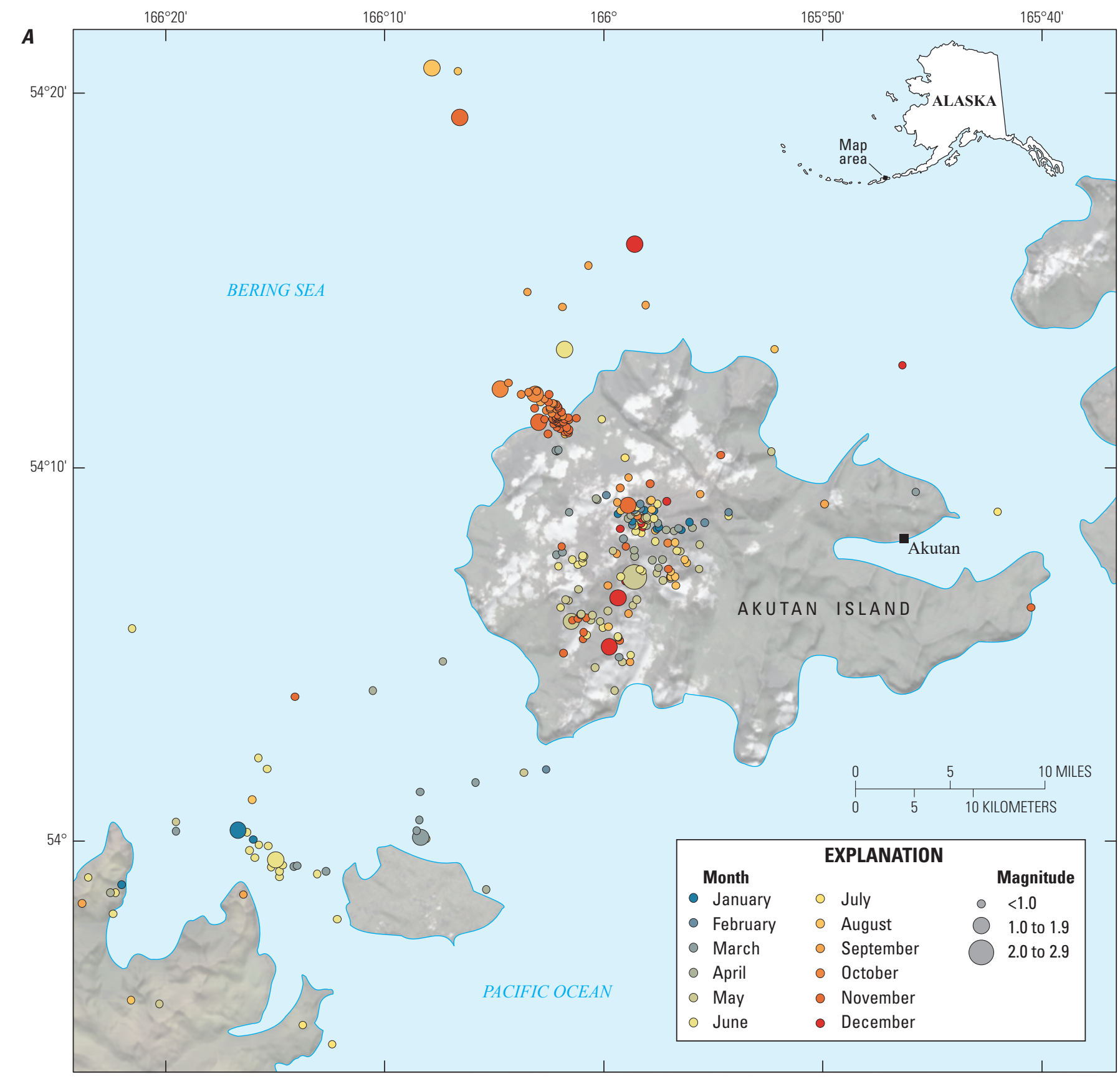

Base from U.S. Geological Survey 60-meter digital data and Alaska statewide imagery from GeoNorth Coordinate system: WGS 1984 Web Mercator Auxiliary Sphere

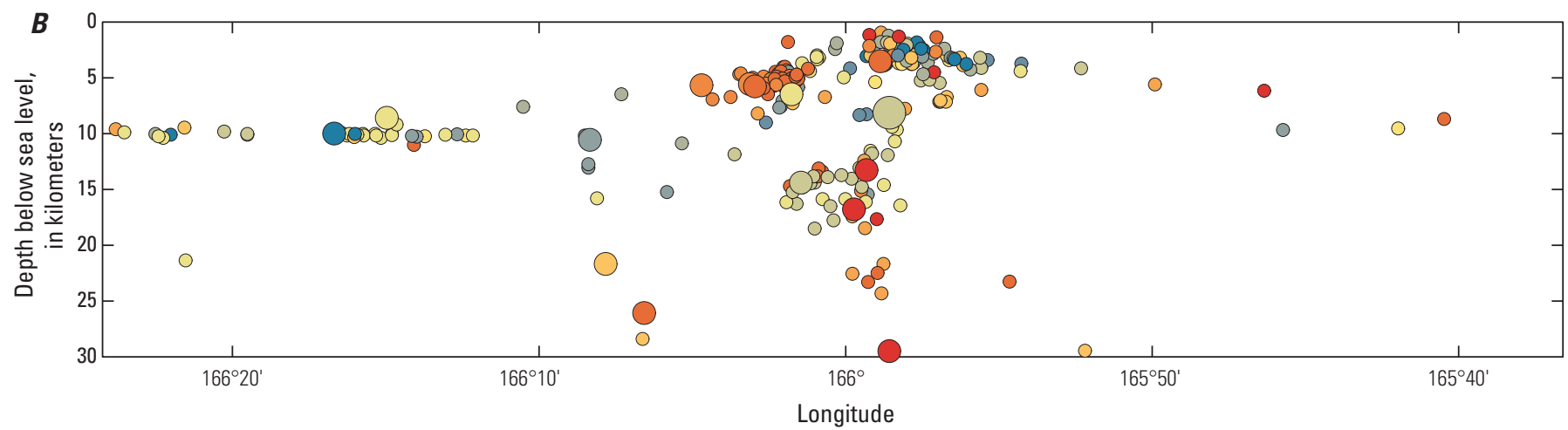

Figure 16. Map of $(A)$ and graph $(B)$ showing seismicity for Akutan Island in 2017. The November 11-13 swarm was located off the northwest coast of the island. 
as much as $\mathrm{M}_{\mathrm{L}}=1.3$. No observed volcanic unrest at Akutan volcano followed the swarm. Tectonic earthquake swarms are commonplace in the Aleutian Islands, and typically an earthquake swarm indicative of an eruption will last longer than three days (Benoit and McNutt, 1996). The Aviation Color Code and Volcano Alert Level remained at GREEN and NORMAL, respectively, throughout the year.

Akutan volcano is one of the most active volcanoes of the Aleutian volcanic arc and has erupted at least 31 times since 1790, most recently in 1992 (McGimsey and others, 1995). The volcano, which occupies the west half of Akutan Island, is a symmetrical stratocone with a 2-km- (1.2-mi-) diameter summit caldera (fig. 17). The caldera is breached to the northwest, and an intracaldera cinder cone has been the site of all historical eruptive activity (Richter and others, 1998; Waythomas and others, 1998). Akutan Island is home to the City of Akutan, Alaska, $12 \mathrm{~km}$ ( $8 \mathrm{mi})$ east of Akutan volcano. It has one of the largest seafood-processing plants in the region, $11 \mathrm{~km}$ (6.6 mi) east of the volcano. In March 1996, two strong swarms of earthquakes occurred on the island, causing minor damage and prompting some residents and seafood-processing plant workers to leave the island ( $\mathrm{Lu}$ and others, 2000). In response, a permanent seismic network was installed in summer 1996.

\author{
Makushin Volcano \\ GVP\# 311310 \\ $53.8871^{\circ} \mathrm{N} ., 166.9320^{\circ} \mathrm{W}$. \\ $1,800 \mathrm{~m}(5,906 \mathrm{ft})$
}

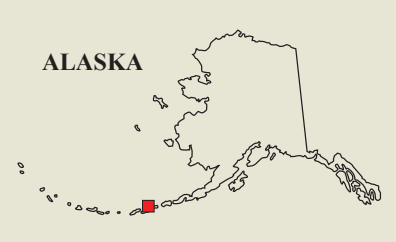

Unimak Island, Fox Islands, Aleutian Islands

EARTHQUAKE SWARM, GAS PLUME

Earthquake swarms are common near Makushin Volcano, and in 2017 several such short earthquake swarms that did not result in eruptive activity occurred (fig. 18). The number of located earthquakes on Unalaska Island continued to increase in 2017, which is a trend that began in 2012. Located earthquakes totaled 236 in 2012, and the number of located earthquakes rose an average of 124 earthquakes per year to 857 in 2017. The increase in seismicity is unrelated to any changes in the seismograph network configuration because the depth and magnitude ranges are similar when the earthquakes located between 2012 and 2017 are compared to the earthquakes detected a decade earlier (fig. 19). AVO continues to monitor this seismicity closely because the cause of any single earthquake swarm may or may not be related to volcanism.

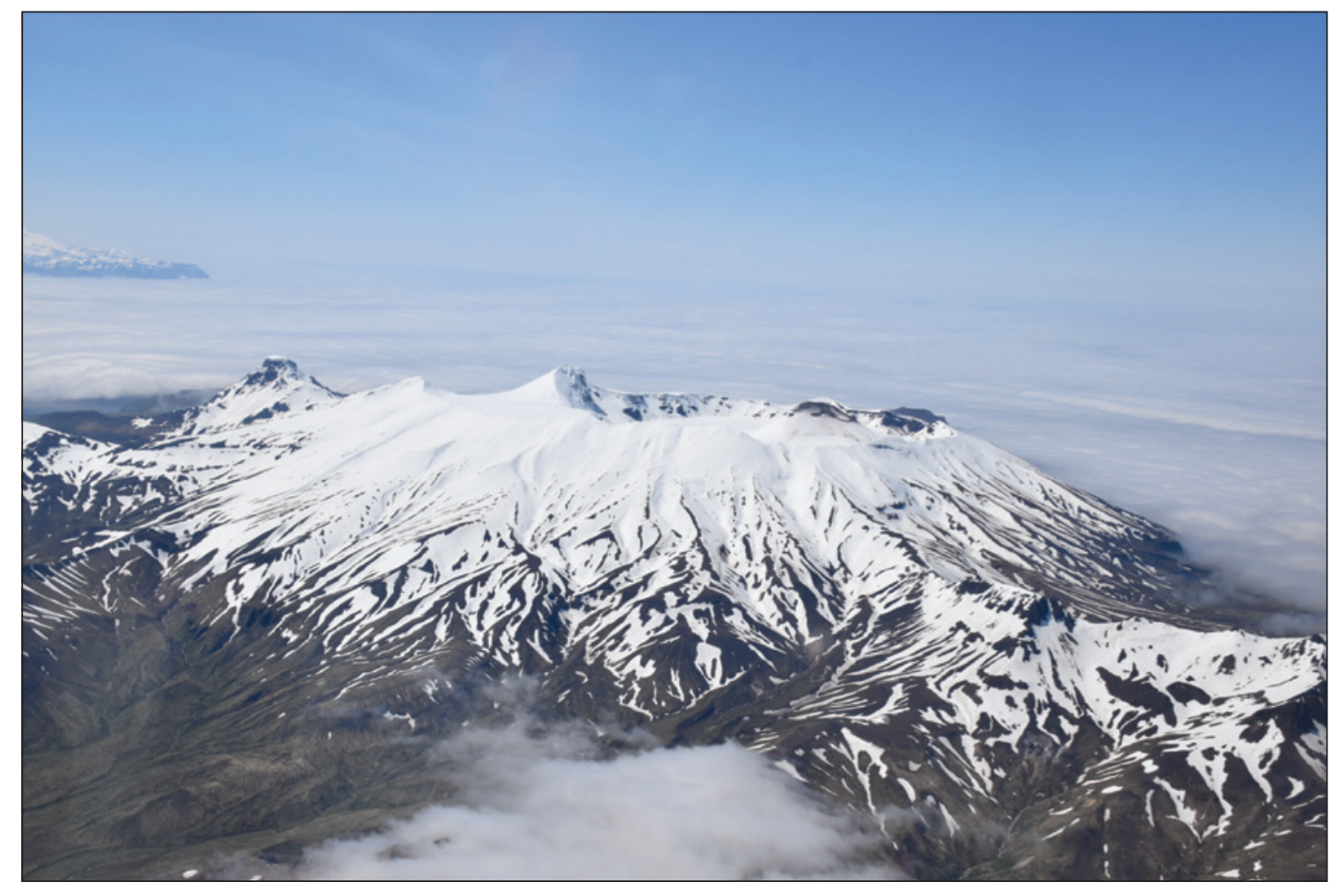

Figure 17. Aerial photograph of Akutan volcano taken by Vlad Karpayev on June 11, 2018. 


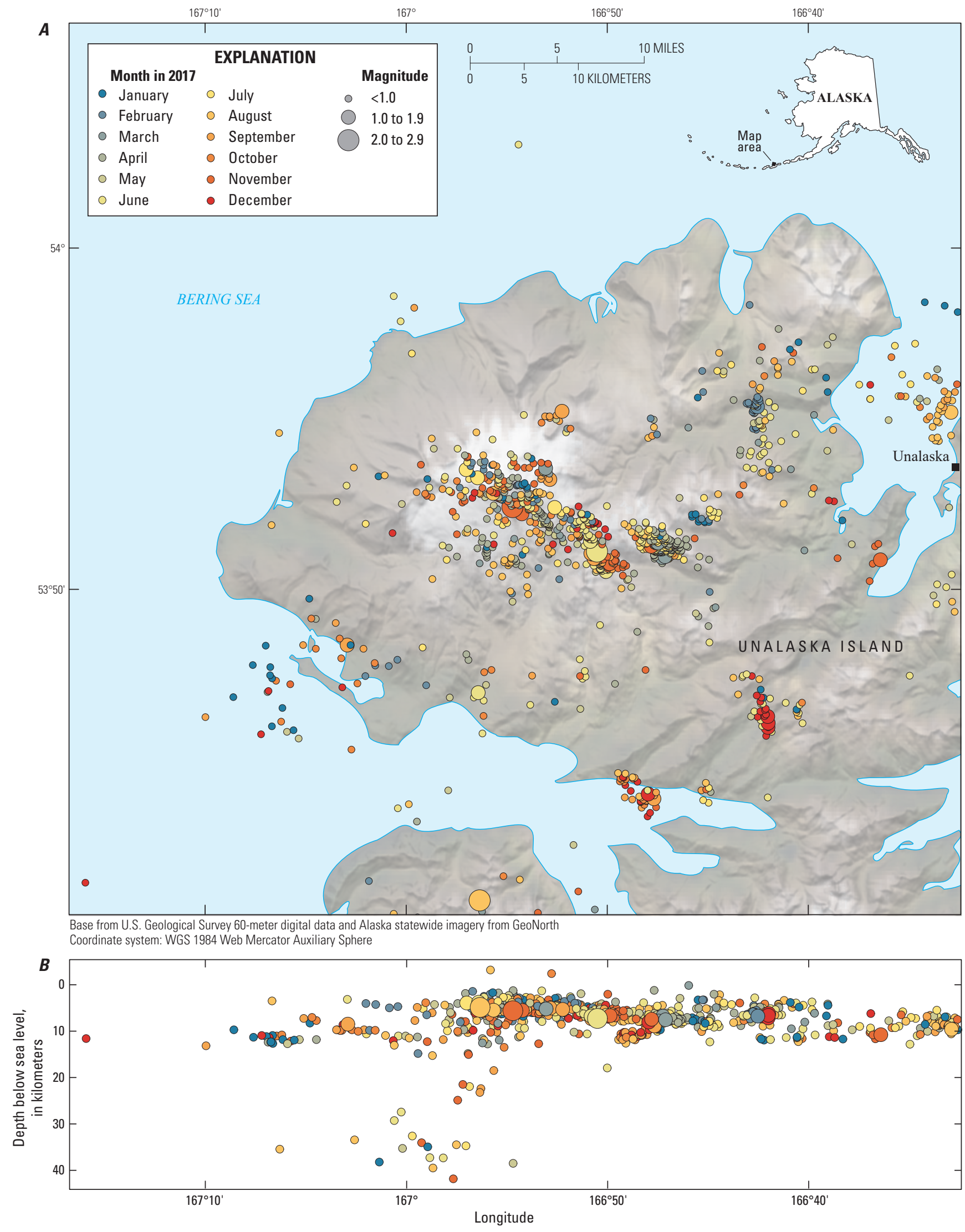

Figure 18. $\operatorname{Map}(A)$ and graph $(B)$ showing seismicity on Unalaska Island in 2017. 

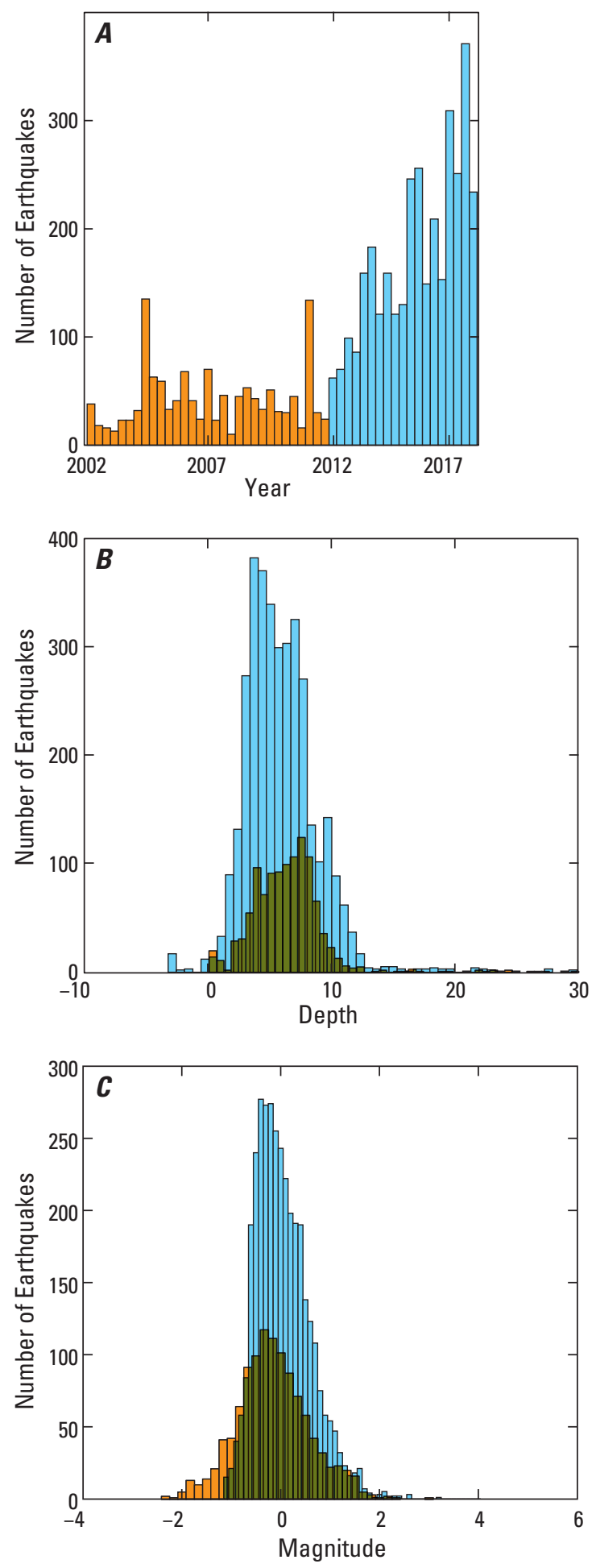

Figure 19. Bar graphs showing earthquake comparison at Makushin Volcano between 2002 and 2017. Earthquakes in the period 2002-11 are in orange. Earthquakes in the period 2012-2017 are in blue. $A$, Earthquakes in 2002-11 averaged 143 earthquakes per year. Earthquakes in 2012-17 averaged 559 earthquakes per year. Each bar represents about four months of data. $B$, Comparison of depths from earthquakes before 2012 and after. $C$, Comparison of magnitudes for earthquakes before 2012 and after.
In November, a citizen observer contacted AVO about an unusual brown haze over Unalaska Island that appeared on November 10 and tapered off over the next two days. AVO scientists searched for a volcanic cause. Nearby active volcanoes, Bogoslof and Cleveland, were quiet and wind patterns would not carry resuspension ash towards the observer. AVO believes the haze had a non-volcanic cause. The Aviation Color Code remained at GREEN and Volcano Alert Level NORMAL for Makushin Volcano throughout 2017.

Makushin Volcano is located on the eastern Aleutian island of Unalaska, about $25 \mathrm{~km}$ (15.5 mi) west of the city of Unalaska-Dutch Harbor, Alaska, an active fishing port (fig. 20). The volcano is a broad, truncated, and deeply glaciated stratovolcano with a $3 \mathrm{~km}$ (1.9 mi) wide summit caldera. Over the years as the ice cover has retreated, a small intracaldera cinder cone that hosts a turquoise-colored lake and abundant fumaroles has become a prominent feature near Makushin. The summit region is capped by a 40 square kilometers $\left(\mathrm{km}^{2}\right.$; about 15 square miles $\left.\left[\mathrm{mi}^{2}\right]\right)$ icefield. Makushin Volcano is credited with 18 historical eruptions, the latest of which occurred on January 30, 1995, and consisted of a small summit explosion and ash plume that rose as high as 3,000 m $(10,000 \mathrm{ft}$; McGimsey and Neal, 1996; McConnell and others, 1998; Begét and others, 2000).

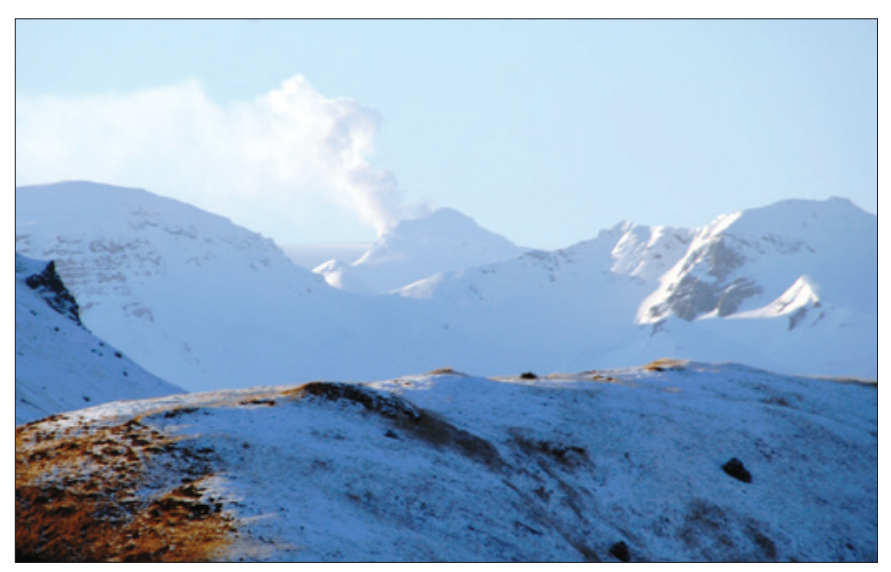

Figure 20. Photograph of Makushin Volcano showing a gas plume rising from the summit region viewed from Dutch Harbor on December 25, 2017. Photograph by James Price. 


\section{Bogoslof Island}

GVP\# 311300

$52.9272^{\circ} \mathrm{N} ., 168.0344^{\circ} \mathrm{W}$.

$150 \mathrm{~m}(492 \mathrm{ft})$

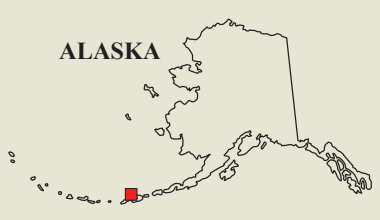

Fox Islands, Aleutian Islands

\section{SIGNIFICANT ERUPTION}

Eruptive activity at Bogoslof Island (herein called Bogoslof volcano to include the surface and submarine expressions of this volcanic system) began in December 2016, continued into 2017, and eventually ended in late August 2017. The last detected eruptive event during 2016-17 occurred on August 30, 2017, and a total of 70 eruptive events were documented between December 12, 2016, and August 30, 2017 (fig. 21; table 5). The 2016-17 eruptive period consisted of two main explosive phases. The first phase lasted from December 12, 2016, to March 13, 2017, and the second phase from May 17 to August 30, 2017. AVO monitored the 9-month long eruptive period using a combination of geophysical instruments and techniques, which included seismograph instruments on nearby Umnak and Unalaska Islands (fig. 22), infrasound sensors on Adak, Chuginadak, Umnak, and Unalaska Islands, lightning detection data from the Vaisala and World Wide Lightning Location networks, various satellite observations, and occasional eyewitness observations (Coombs and others, 2018). A special volume about the 2016-17

Bogoslof volcano eruption was published (Waythomas and others, 2019) and contains more details than can be presented here.

All eruptive events began at shallow ( $<150 \mathrm{~m}$ water depth) submarine vents. The vents either remained submerged throughout the duration of the eruptive event or became drier and emergent as eruptive activity proceeded and as water was displaced or isolated from the locus of eruptive activity. The explosive events that characterized the eruption lasted minutes to tens of minutes, which produced volcanic clouds that rose as high as $14 \mathrm{~km}(46,000 \mathrm{ft})$ and were often associated with abundant lightning, $\mathrm{SO}_{2}$ emissions and occasional volcanic thunder (Haney and others, 2018). During December 2016 and January 2017, eruptive events occurred every 1 to 4 days. The rate of events declined in February 2017, and a short hiatus occurred from mid-March to mid-May. Explosive activity resumed on May 17, 2017, and continued intermittently in June, July, and August 2017.

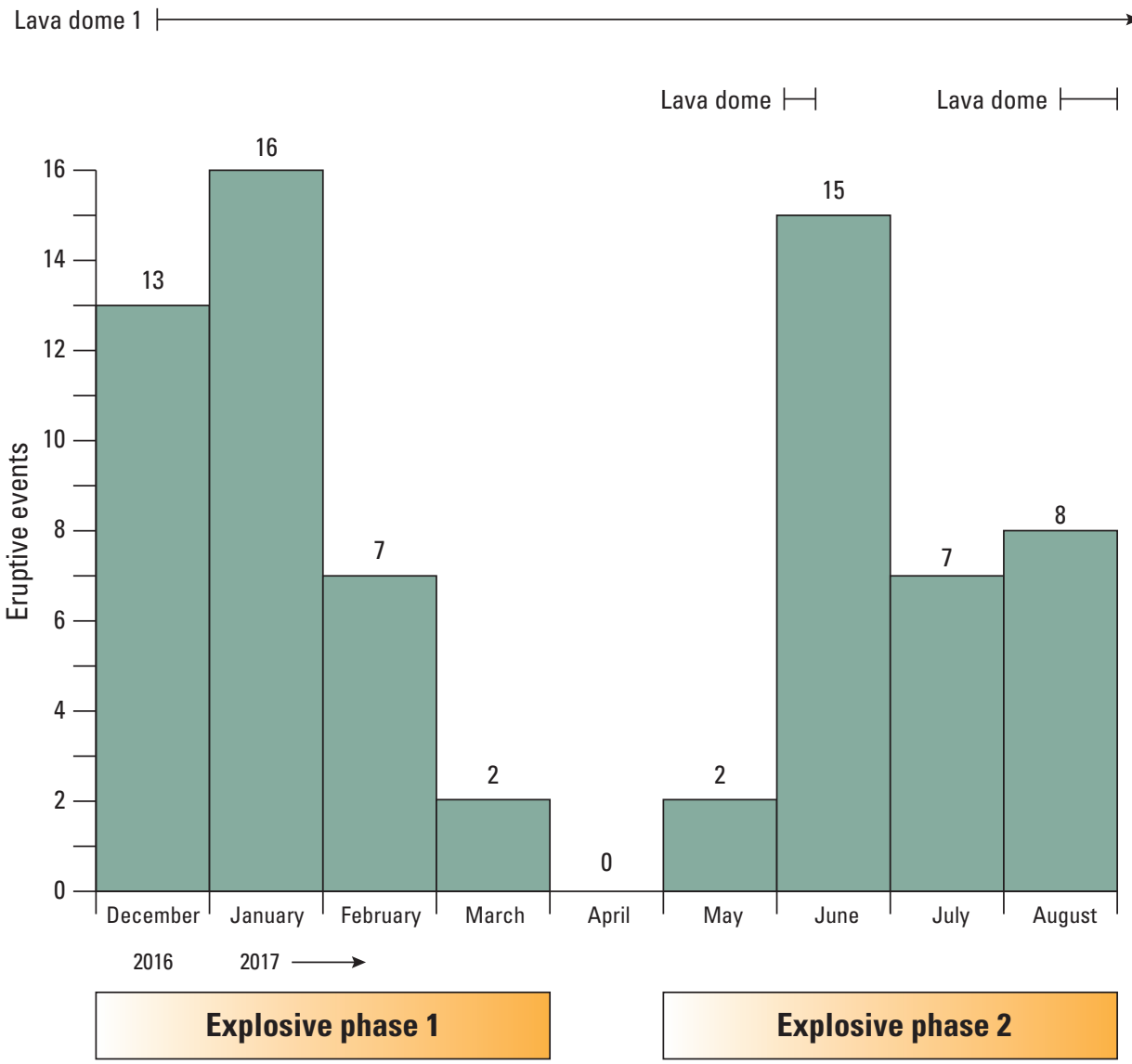

Figure 21. Bar graphs showing number of detected explosive events per month for the 2016-17 Bogoslof volcano. The timing of lava dome formations is also shown. 
Table 5. Summary of significant events and Aviation Color Code and Volcanic Alert Level changes during the 2016-17 Bogoslof volcano eruption.

[Bogoslof volcano has no geophysical network. All mention of seismic and infrasound data is from networks located on Umnak and Unalaska Islands (about 40 and $60 \mathrm{~km}$ south and east of Bogoslof volcano, respectively). Table is based on chronology developed by Alaska Volcano Observatory (AVO) staff, especially Kristi Wallace, U.S. Geological Survey (USGS)-AVO, Dave Schneider, USGS-AVO, and David Fee, University of Alaska Fairbanks Geophysical Institute-AVO. All dates are listed in month, day, and year format and in Universal Coordinated Time (UTC); ASL, above sea level; ft, feet; km, kilometer; $\mathrm{SO}_{2}$, sulfur dioxide]

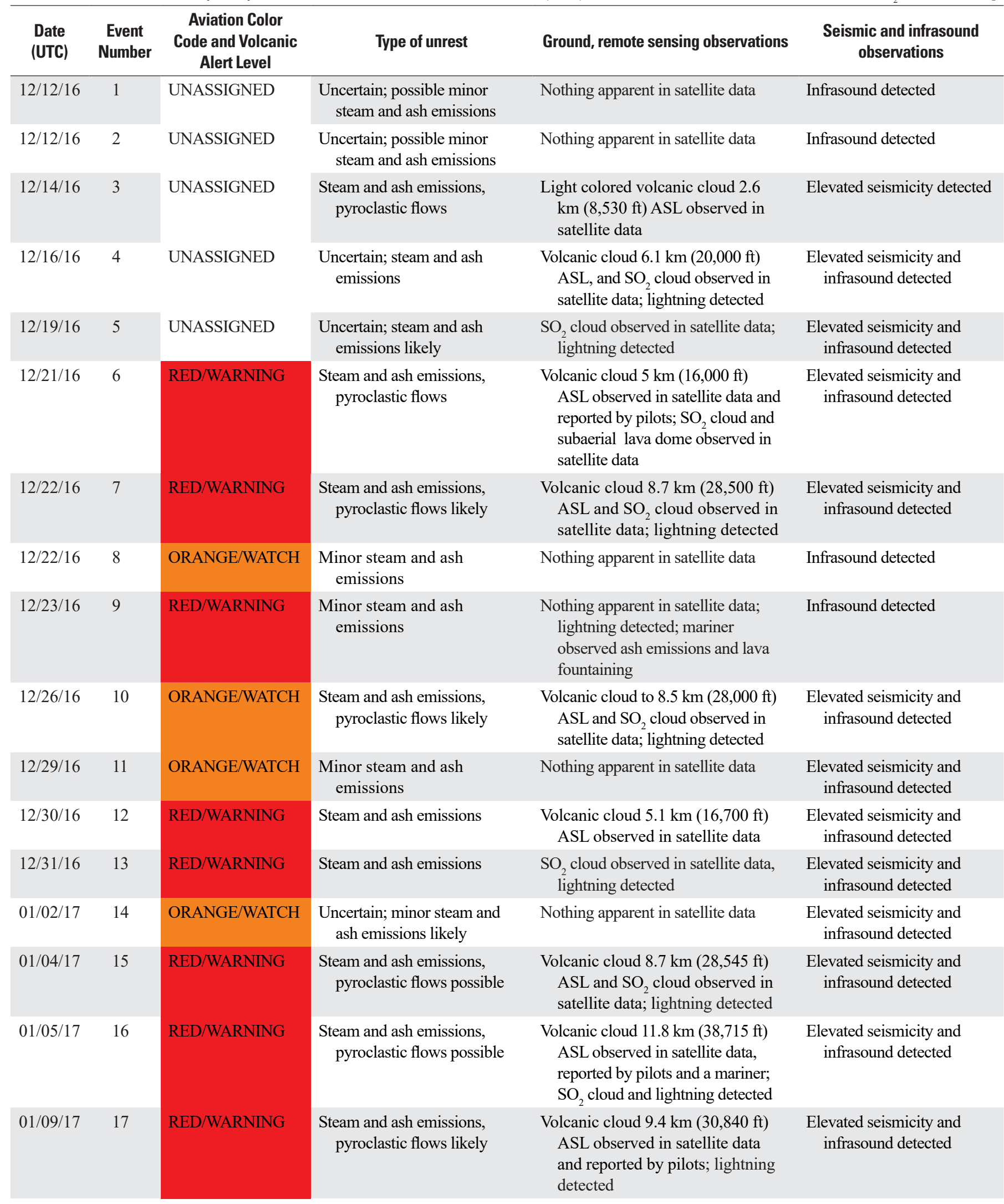


Table 5.-Continued

\begin{tabular}{|c|c|c|c|c|c|}
\hline $\begin{array}{l}\text { Date } \\
\text { (UTC) }\end{array}$ & $\begin{array}{l}\text { Event } \\
\text { Number }\end{array}$ & $\begin{array}{l}\text { Aviation Color } \\
\text { Code and Volcanic } \\
\text { Alert Level }\end{array}$ & Type of unrest & Ground, remote sensing observations & $\begin{array}{l}\text { Seismic and infrasound } \\
\text { observations }\end{array}$ \\
\hline $01 / 12 / 17$ & 18 & ORANGE/WATCH & $\begin{array}{l}\text { Minor steam and ash } \\
\text { emissions }\end{array}$ & $\begin{array}{l}\text { Small volcanic cloud } 3.7 \mathrm{~km} \\
\quad(12,140 \mathrm{ft}) \text { ASL observed in satellite } \\
\text { data and reported by a pilot }\end{array}$ & Elevated seismicity detected \\
\hline $01 / 12 / 17$ & 19 & ORANGE/WATCH & $\begin{array}{l}\text { Minor steam and ash } \\
\text { emissions }\end{array}$ & $\begin{array}{l}\text { Small volcanic cloud } 3.4 \mathrm{~km} \\
\quad(11,155 \mathrm{ft}) \text { ASL observed in } \\
\text { satellite data and reported by pilots }\end{array}$ & Elevated seismicity detected \\
\hline $01 / 15 / 17$ & 20 & ORANGE/WATCH & $\begin{array}{l}\text { Steam and ash emissions, } \\
\text { pyroclastic flows possible }\end{array}$ & $\begin{array}{l}\mathrm{SO}_{2} \text { cloud observed in satellite data; } \\
\text { lightning detected }\end{array}$ & $\begin{array}{l}\text { Elevated seismicity and } \\
\text { infrasound detected }\end{array}$ \\
\hline $01 / 17 / 17$ & 21 & ORANGE/WATCH & $\begin{array}{l}\text { Steam and ash emissions, } \\
\text { pyroclastic flows possible }\end{array}$ & $\mathrm{SO}_{2}$ cloud observed.in satellite data & $\begin{array}{l}\text { Elevated seismicity and } \\
\text { infrasound detected }\end{array}$ \\
\hline $01 / 17 / 17$ & 22 & ORANGE/WATCH & $\begin{array}{l}\text { Steam and ash emissions, } \\
\text { pyroclastic flows possible }\end{array}$ & Nothing apparent in satellite data & $\begin{array}{l}\text { Elevated seismicity and } \\
\text { infrasound detected }\end{array}$ \\
\hline $01 / 20 / 17$ & 24 & RED/WARNING & $\begin{array}{l}\text { Steam and ash emissions, } \\
\text { pyroclastic flows likely }\end{array}$ & $\begin{array}{l}\text { Volcanic cloud } 7.5 \mathrm{~km} \text { ASL observed in } \\
\text { satellite data and reported by pilots; } \\
\mathrm{SO}_{2} \text { cloud and lightning detected }\end{array}$ & $\begin{array}{l}\text { Elevated seismicity and } \\
\text { infrasound detected }\end{array}$ \\
\hline $01 / 22 / 17$ & 25 & RED/WARNING & Steam and ash emissions & $\begin{array}{l}\text { Volcanic cloud } 6.6 \mathrm{~km}(21,655 \mathrm{ft}) \\
\mathrm{ASL} \text { and } \mathrm{SO}_{2} \text { cloud observed in } \\
\text { satellite data; lightning detected }\end{array}$ & Infrasound detected \\
\hline $01 / 24 / 17$ & 26 & RED/WARNING & $\begin{array}{l}\text { Steam and ash emissions, } \\
\text { pyroclastic flows likely }\end{array}$ & $\begin{array}{l}\text { Volcanic cloud } 7 \mathrm{~km}(22,965 \mathrm{ft}) \mathrm{ASL} \\
\text { and } \mathrm{SO}_{2} \text { cloud observed in satellite } \\
\text { data; lightning detected }\end{array}$ & $\begin{array}{l}\text { Elevated seismicity and } \\
\text { infrasound detected }\end{array}$ \\
\hline $01 / 31 / 17$ & 29 & RED/WARNING & $\begin{array}{l}\text { Steam and ash emissions, } \\
\text { pyroclastic flows likely. } \\
\text { Ballistic ejecta generated }\end{array}$ & $\begin{array}{l}\text { Volcanic cloud } 5.9 \mathrm{~km}(19,360 \mathrm{ft}) \\
\text { ASL and } \mathrm{SO}_{2} \text { cloud observed in } \\
\text { satellite data; lightning detected; } \\
\text { trace ashfall reported at Dutch } \\
\text { Harbor/Unalaska }\end{array}$ & $\begin{array}{l}\text { Elevated seismicity and } \\
\text { long-duration ( } 400 \\
\text { minutes) infrasound } \\
\text { detected }\end{array}$ \\
\hline $02 / 03 / 17$ & 30 & ORANGE/WATCH & $\begin{array}{l}\text { Minor steam and ash emissions } \\
\text { likely }\end{array}$ & Nothing apparent in satellite data & $\begin{array}{l}\text { Elevated seismicity and } \\
\text { infrasound detected }\end{array}$ \\
\hline $02 / 04 / 17$ & 31 & ORANGE/WATCH & $\begin{array}{l}\text { Steam and ash emissions, } \\
\text { pyroclastic flows likely }\end{array}$ & $\begin{array}{l}\text { Volcanic cloud } 4.6 \mathrm{~km}(15,100 \mathrm{ft}) \\
\text { ASL observed in satellite data and } \\
\text { reported by pilots; elevated surface } \\
\text { temperatures observed in satellite } \\
\text { data }\end{array}$ & $\begin{array}{l}\text { Elevated seismicity and } \\
\text { infrasound detected }\end{array}$ \\
\hline $02 / 13 / 17$ & 32 & ORANGE/WATCH & $\begin{array}{l}\text { Possible minor steam and ash } \\
\text { emissions }\end{array}$ & $\begin{array}{l}\text { Volcanic cloud } 5.9 \mathrm{~km}(19,350 \mathrm{ft}) \\
\text { observed in in satellite data }\end{array}$ & Elevated seismicity detected \\
\hline $02 / 17 / 17$ & 33 & RED/WARNING & $\begin{array}{l}\text { Steam and ash emissions, } \\
\text { pyroclastic flows likely }\end{array}$ & $\begin{array}{l}\text { Volcanic cloud } 5.9 \mathrm{~km}(19,350 \mathrm{ft}) \\
\text { ASL and } \mathrm{SO}_{2} \text { cloud observed } \\
\text { in satellite data and reported by } \\
\text { pilots; lightning detected }\end{array}$ & $\begin{array}{l}\text { Elevated seismicity and } \\
\text { infrasound detected }\end{array}$ \\
\hline
\end{tabular}


Table 5.-Continued

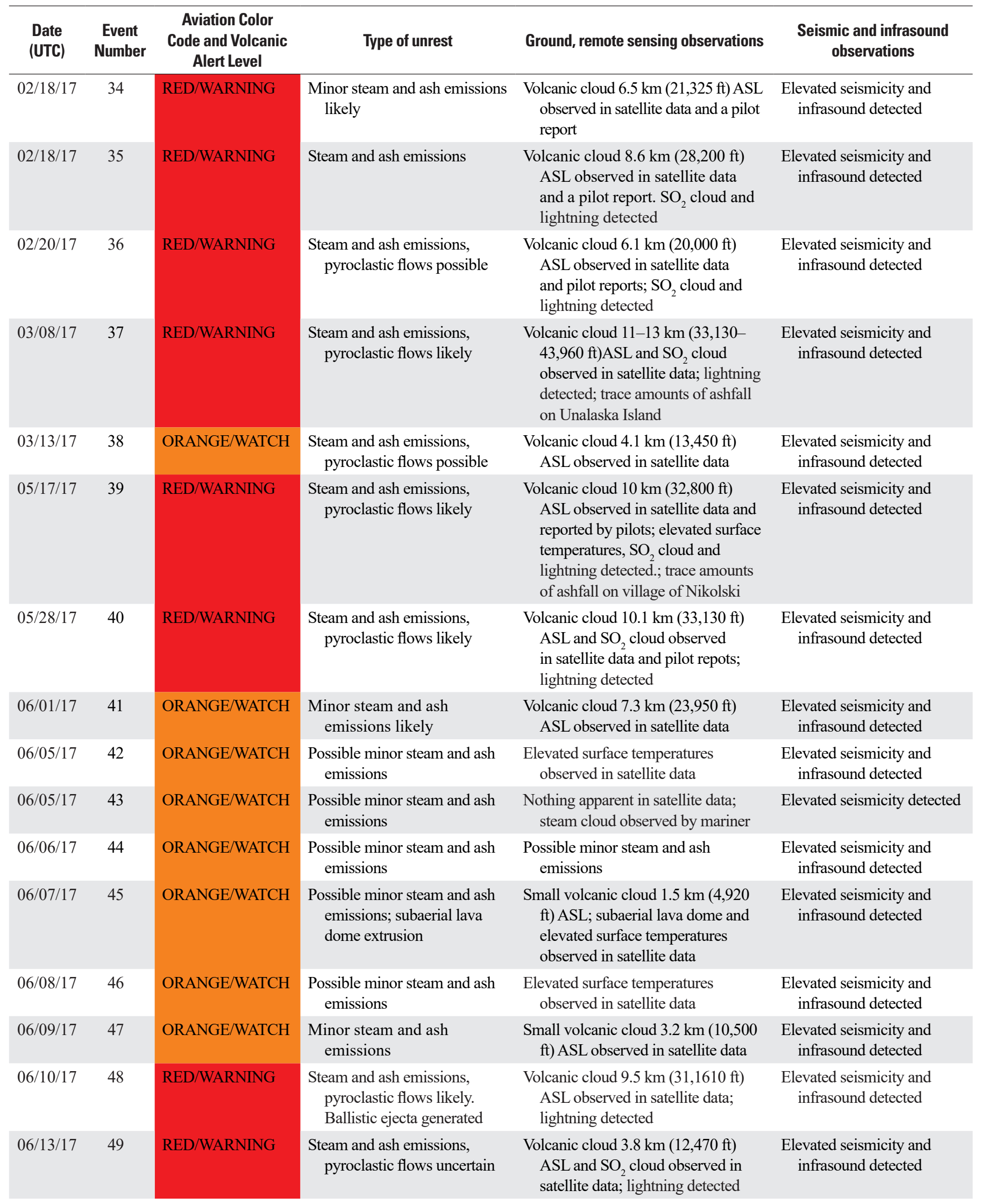


Table 5.-Continued

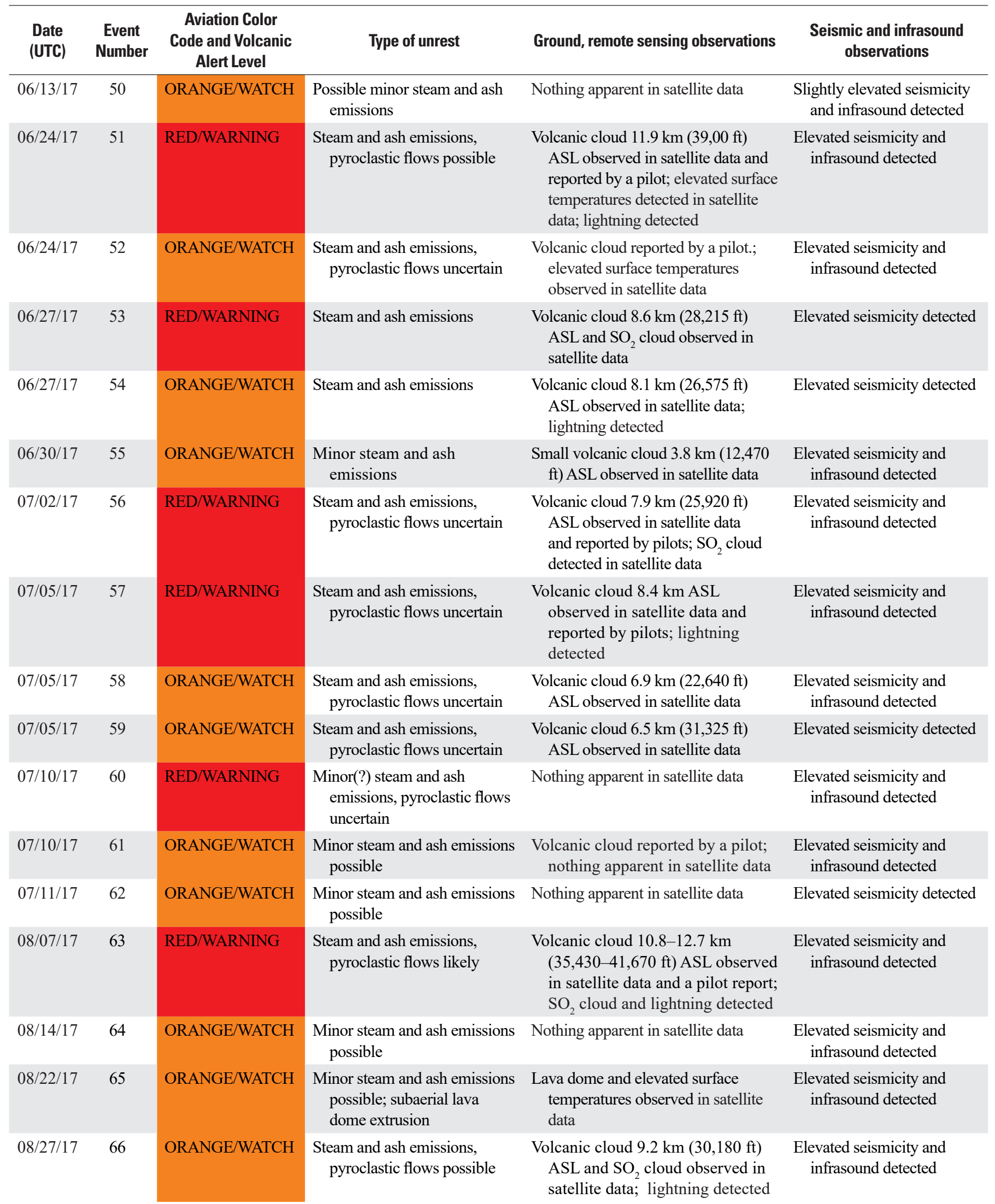


Table 5.-Continued

\begin{tabular}{|c|c|c|c|c|c|}
\hline $\begin{array}{l}\text { Date } \\
\text { (UTC) }\end{array}$ & $\begin{array}{l}\text { Event } \\
\text { Number }\end{array}$ & $\begin{array}{l}\text { Aviation Color } \\
\text { Code and Volcanic } \\
\text { Alert Level }\end{array}$ & Type of unrest & Ground, remote sensing observations & $\begin{array}{c}\text { Seismic and infrasound } \\
\text { observations }\end{array}$ \\
\hline $08 / 27 / 17$ & 67 & ORANGE/WATCH & Minor steam and ash emissions & $\begin{array}{l}\text { Volcanic cloud } 8.7 \mathrm{~km}(28,540 \mathrm{ft}) \\
\text { ASL observed in satellite data and } \\
\text { a pilot report }\end{array}$ & $\begin{array}{l}\text { Elevated seismicity and } \\
\text { infrasound detected }\end{array}$ \\
\hline $08 / 28 / 17$ & 68 & ORANGE/WATCH & $\begin{array}{l}\text { Minor steam and ash emissions } \\
\text { possible }\end{array}$ & $\begin{array}{l}\text { Elevated surface temperatures and } \\
\mathrm{SO}_{2} \text { cloud observed in satellite } \\
\text { data }\end{array}$ & $\begin{array}{l}\text { Elevated seismicity and } \\
\text { infrasound detected }\end{array}$ \\
\hline $08 / 28 / 17$ & 69 & ORANGE/WATCH & $\begin{array}{l}\text { Minor steam and ash emissions } \\
\text { possible }\end{array}$ & $\begin{array}{l}\text { Volcanic cloud } 6.7 \mathrm{~km}(21,980 \mathrm{ft}) \\
\text { ASL observed in satellite data and } \\
\text { a pilot report ; elevated surface } \\
\text { temperatures and } \mathrm{SO}_{2} \text { cloud } \\
\text { detected in satellite data }\end{array}$ & $\begin{array}{l}\text { Elevated seismicity and } \\
\text { infrasound detected }\end{array}$ \\
\hline
\end{tabular}

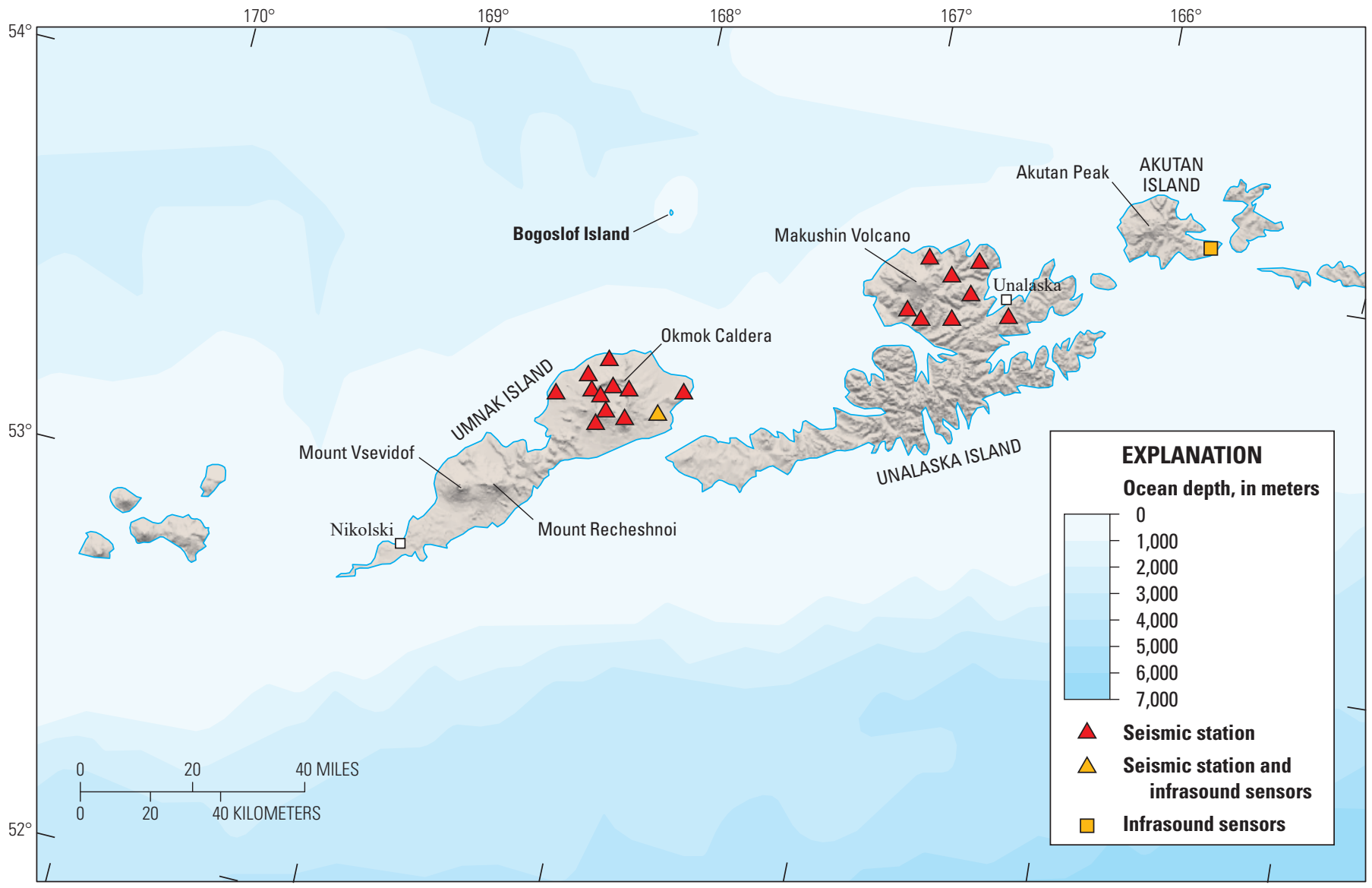

Base from Natural Earth and U.S. Geological Survey digital data

Alaska Albers Equal-Area Conic projection

Standard parallels $55^{\circ} \mathrm{N}$. and $65^{\circ} \mathrm{N}$.

Central meridian $154^{\circ} \mathrm{W}$.

North American Datum of 1983

Figure 22. Map of area around Bogoslof Island showing the location of seismograph and infrasound stations that were prominent in monitoring the 2016-17 Bogoslof volcano eruption. 
A visit to Bogoslof Island by AVO personnel in August 2018 revealed a lava dome partially buried by pyroclastic debris, previously assumed to be a tephra cone associated with Surtseyan eruptive activity. A satellite image from December 21, 2016, showed a feature with positive relief in the general vicinity of the lava dome. Two lava domes were recognized in satellite data from June 5-10, and August 18-30, 2017. Both of the lava domes were destroyed by subsequent explosive activity on June 10 and August 30, 2017. No further explosive activity was detected by AVO after August 30, 2017. Above background surface temperatures associated with hot ground and water in the vent area were detected in satellite data for several months following the cessation of the eruption. On September 27, 2017, AVO lowered the Aviation Color Code and Volcano Alert Level to YELLOW and ADVISORY, respectively, and the volcano returned to a quiescent state by the end of 2017.
As a result of the eruption, Bogoslof Island experienced significant morphological changes and the size of the island grew from about $0.3 \mathrm{~km}^{2}\left(0.1 \mathrm{mi}^{2}\right)$ to about $1.9 \mathrm{~km}^{2}\left(0.7 \mathrm{mi}^{2}\right)$ by the end of the eruptive activity (fig. 23). Several tuff rings were constructed by pyroclastic flows and fallout of ballistic ejecta. The tuff rings often contained small intra-island lakes which were typically the sites of explosive activity and were measurably hot when visited in August 2018, a year after the eruption ended.

Most volcanic clouds produced by the eruptive activity in 2017 were light-colored gas, ice-, and ash-bearing plumes that resulted in minor ash fallout. Trace amounts of ash fell on Unalaska Island on January 31 and March 8 and on the village of Nikolski on May 16, 2017. Numerous flights were rerouted, delayed, or cancelled to avoid volcanic ash, especially during January (Coombs and others, 2019). For example, during the January 18 explosion, about 50 flights were affected (National

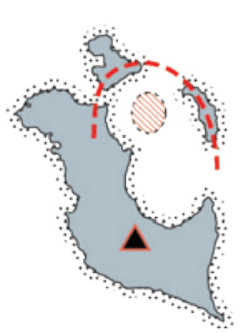

$0.293 \mathrm{~km}^{2}$

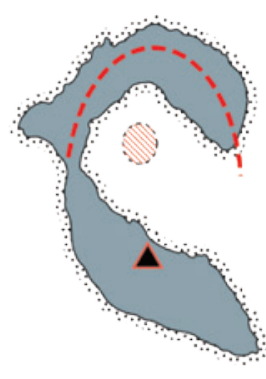

$0.437 \mathrm{~km}^{2}$

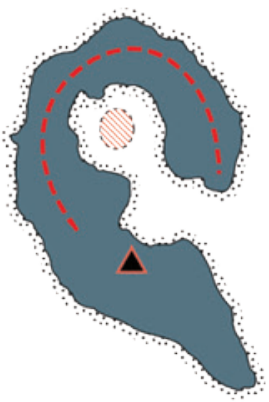

$0.623 \mathrm{~km}^{2}$

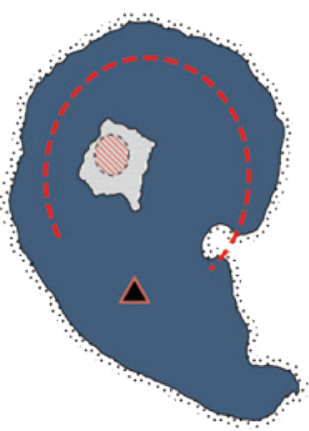

$1.02 \mathrm{~km}^{2}$

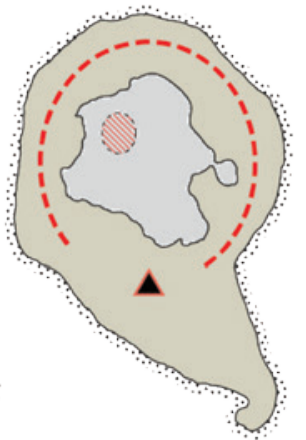

$0.815 \mathrm{~km}^{2}$

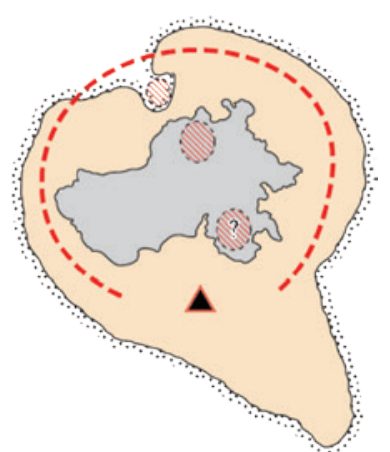

$0.984 \mathrm{~km}^{2}$
May 28, 2017

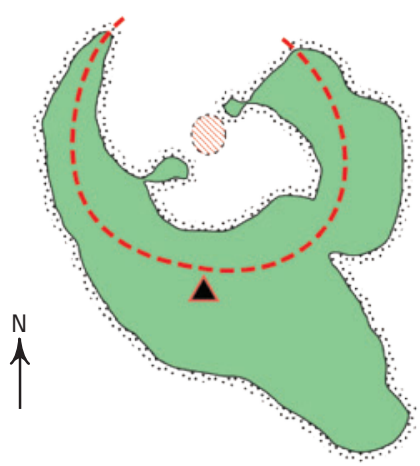

$1.02 \mathrm{~km}^{2}$
June 10, 2017

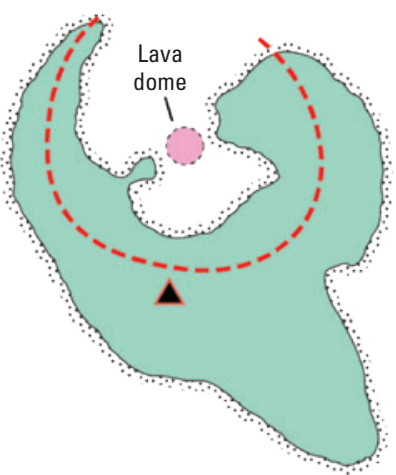

$1.15 \mathrm{~km}^{2}$

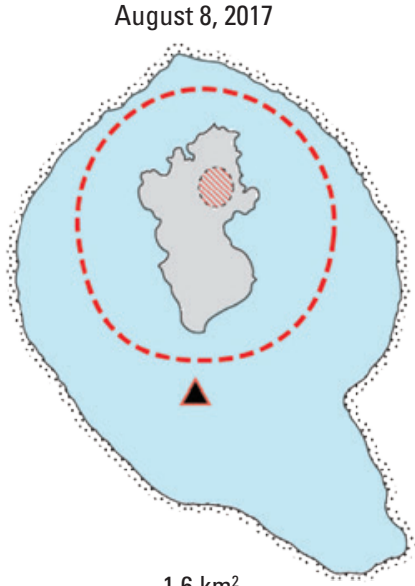

$1.6 \mathrm{~km}^{2}$
September 18, 2017

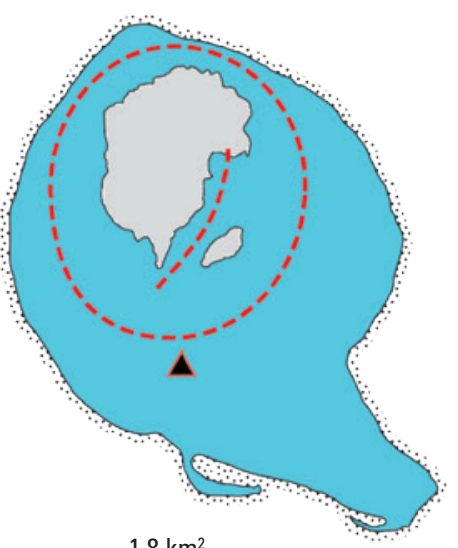

$1.8 \mathrm{~km}^{2}$

\section{EXPLANATION}

Approximate vent location

Shallow seawater lake
- - - Tuff ring centerline

Lava dome

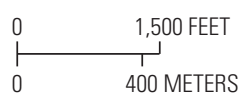

Figure 23. Diagrams showing the changes in the morphology of Bogoslof Island resulting from eruptive activity, December 25, 2016, to September 18, 2017. 
Weather Service Central Weather Service Unit, written communication, 2017). Reduced freight capacity, because of flight cancellations owing to the Bogoslof volcano explosions, were noted in industry websites.

Bogoslof Island (fig. 24) is the largest of a cluster of small, low-lying islands making up the emergent summit of a large submarine stratovolcano. The highest point above sea

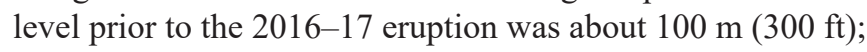
however, the volcano is frequently altered by both eruptions and wave erosion and has undergone dramatic changes in historical time (Waythomas and Cameron, 2018). The two main islands currently above sea level are Fire Island and Bogoslof Island; both located about $98 \mathrm{~km}(61 \mathrm{mi})$ northwest of Unalaska-Dutch Harbor, Alaska, $123 \mathrm{~km}$ (76 mi) northeast of Nikolski, Alaska, and $149 \mathrm{~km}(93 \mathrm{mi})$ northeast of Akutan, Alaska. The volcano is situated slightly north (behind) of the main Aleutian volcanic front.

At least eight historical eruptions have been documented at Bogoslof volcano (Waythomas and Cameron, 2018). The most recent eruption prior to 2016-17 occurred in July 1992 and produced episodic steam and ash emissions including an ash cloud as high as $8 \mathrm{~km}(26,000 \mathrm{ft})$ ASL on July 20 , followed by extrusion of a $150 \mathrm{~m}(500 \mathrm{ft})$ by $275 \mathrm{~m}(900 \mathrm{ft})$ lava dome on the north end of the island. Eruptions of the volcano are often characterized by multiple explosive, ash-producing events such as those observed in 2016-2017, as well as the growth of new lava domes.

\section{Okmok Caldera}

GVP\# 311290

$53.419^{\circ} \mathrm{N} ., 168.132^{\circ} \mathrm{W}$.

$1,073 \mathrm{~m}(3,520 \mathrm{ft})$

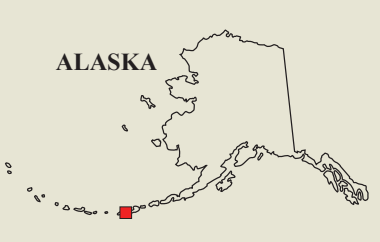

Fox Islands, Aleutian Islands

\section{INFLATION}

Gradual inflation at Okmok Caldera (herein called Okmok volcano to include associated volcanic features exterior to the caldera) was first noticed in September 2016 on GPS sensors and continued into 2017. In April, a northtrending inflation signal suggested a higher rate of inflation at Okmok volcano. Throughout the rest of 2017, the inflation signal continued, extending into 2018 without abatement and without evidence of an imminent eruption. The Aviation Color Code remained at GREEN and Volcano Alert Level NORMAL throughout 2017.

Okmok volcano occupies most of northeast Umnak Island (120 km [75 mi] southwest of Unalaska-Dutch Harbor, Alaska). It consists of younger lava flows and cones within two nested Quaternary calderas and numerous older flows and cones outside of the calderas, including Jag Peak and Mount Tulik (fig. 25). The volcano, built on a base of Tertiary volcanic rocks, consists of three rock series: (1) older flows

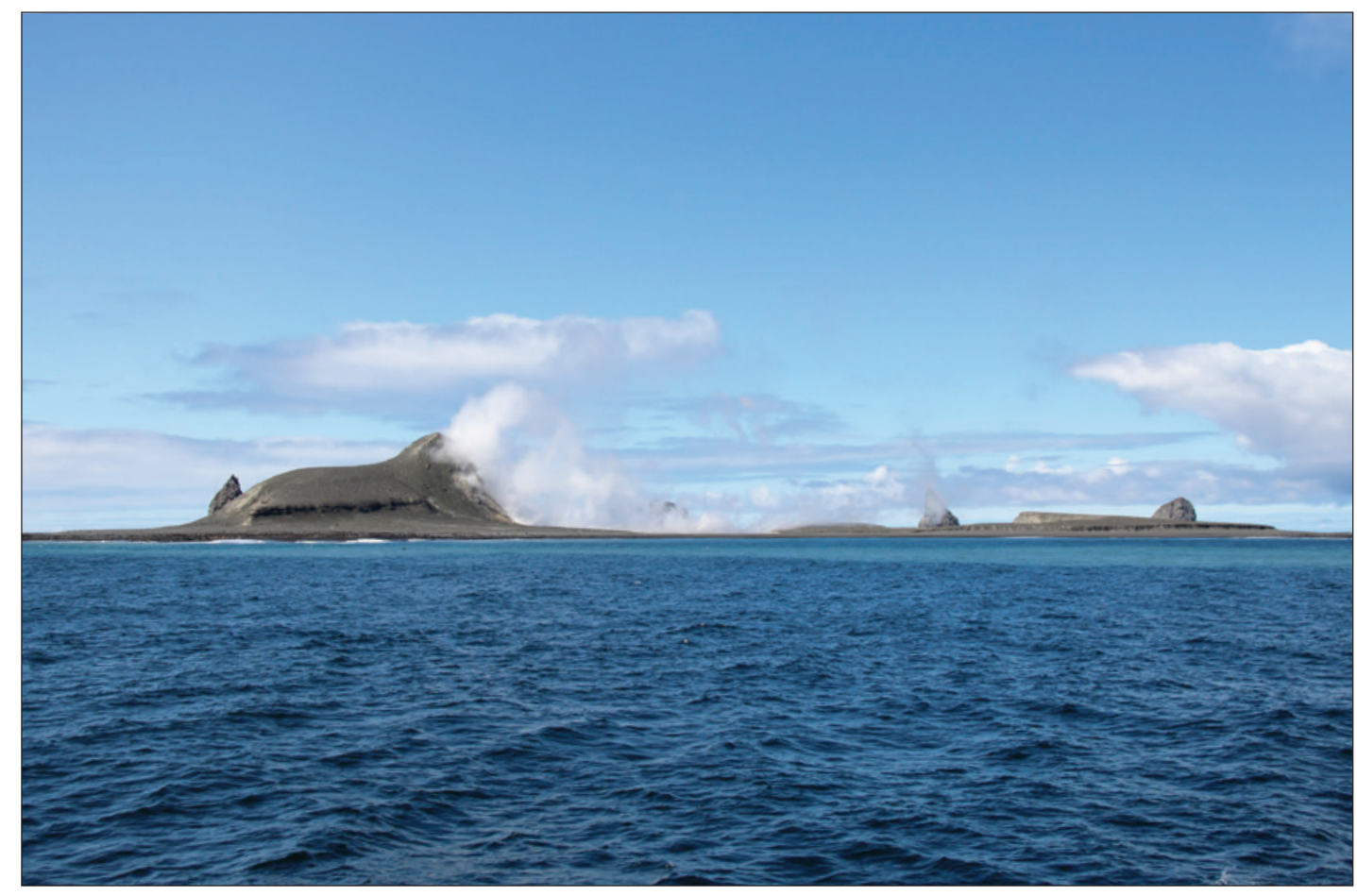

Figure 24. U.S. Geological Survey photograph of Bogoslof Island from the northwest on August 16, 2018, showing the domes above sea level. Features from left to right are: Castle Rock, degassing 2016-17 dome, 1926-27 dome (mostly obscured by gas plume), 1992 dome, and Fire Island. Photograph by Gabrielle Tepp. 


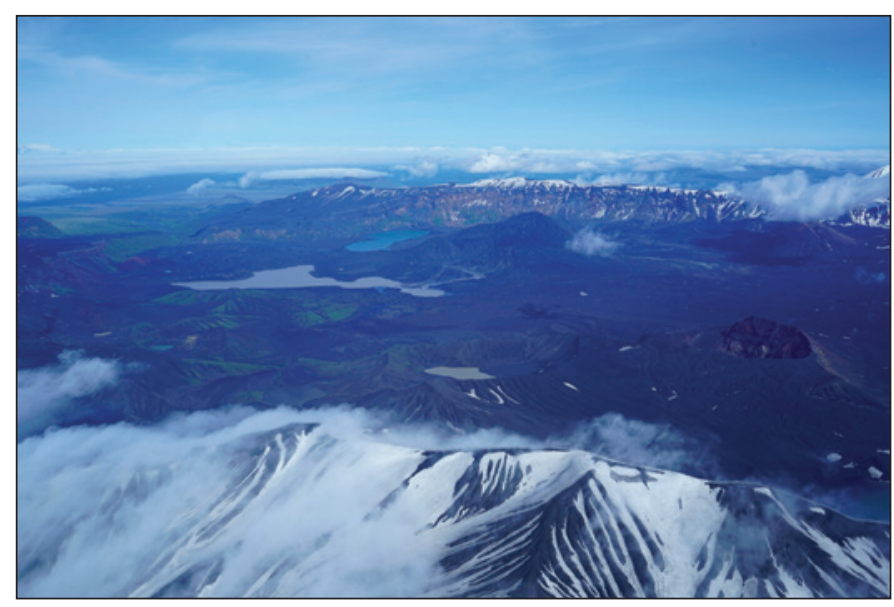

Figure 25. Photograph of $0 \mathrm{kmok}$ Caldera looking east from the caldera rim on July 16, 2018. Photograph by David Fee, University of Alaska Fairbanks Geophysical Institute-Alaska Volcano Observatory.

and pyroclastic beds of a pre-caldera shield complex, (2) pyroclastic deposits of two major caldera-forming eruptions, and (3) a post-caldera field of small cones and lava flows that includes historically active vents in the caldera (Byers, 1959; Larsen and others, 2007). Okmok volcano has had several eruptions in the past several hundred years, typically consisting of ash emissions that occasionally reach altitudes higher than $9 \mathrm{~km}(30,000 \mathrm{ft})$, but generally much lower. In the past 70 years, lava flows were emplaced on the caldera floor in 1945, 1958, and 1997 (Begét and others, 2005). The most recent eruption was a phreatomagmatic eruption during summer 2008 (Neal and others, 2011). Thermal springs and fumaroles occur in the Okmok Caldera and at Hot Springs Cove, $20 \mathrm{~km}$ (12 mi) to the southwest.

\section{Mount Cleveland}

GVP\# 311240

$52.8222^{\circ} \mathrm{N} ., 169.9450^{\circ} \mathrm{W}$. $1,730 \mathrm{~m}(5,676 \mathrm{ft})$

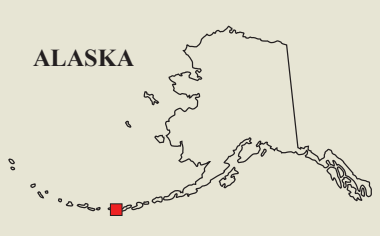

Chuginadak Island, Fox Islands, Aleutian Islands

\section{CONTINUED LOW-LEVEL ERUPTION}

Mount Cleveland began the seventh straight year at an elevated Aviation Color Code and Volcano Alert Level in 2017. Activity consisted of intermittent elevated surface temperatures, degassing from the summit cone, and the extrusion of small lava domes punctuated by explosions (table 6). Mount Cleveland began 2017 with fewer but similarly sized explosions to those in previous years that transitioned into more frequent but smaller explosions towards the end of the year. The volcano is currently monitored with a small network of seismograph and infrasound sensors, a web camera, and satellite remote sensing, With these data streams available throughout the year for the first time, AVO is better able to characterize the ongoing activity at Mount Cleveland. Because of the low number of seismographic stations (2), AVO is unable to locate the types of earthquakes needed to assist in the prediction of an eruption at Mount Cleveland, and it is not formally listed as a seismically monitored volcano.

Mount Cleveland began 2017 at Aviation Color Code YELLOW and Volcano Alert Level ADVISORY. The last explosion in October 24, 2016, left a deep crater at the start of 2017. Activity in January consisted of intermittent gas plumes and elevated surface temperatures. By January 21, satellite imagery confirmed that a new lava dome partially occupied the summit crater. The dome measured $30 \mathrm{~m}(100 \mathrm{ft})$ in diameter on January 24, and by February 3 it was $70 \mathrm{~m}$ (230 ft) in diameter. The extrusion of this lava dome and potential for explosive activity prompted AVO to increase the Aviation Color Code to ORANGE and the Volcano Alert Level to WATCH on February 3. The dome ceased growing at $75 \mathrm{~m}(250 \mathrm{ft})$ in diameter around February 11 and remained unchanged into March, and weakly elevated surface temperatures and minor gas emissions were detected in satellite imagery and web-cameras during this time, consistent with cooling lava. After several weeks of inactivity, the Aviation Color Code and Volcano Alert Level was downgraded from ORANGE and WATCH to YELLOW and ADVISORY, respectively, on March 8.

The first explosion of 2017, which occurred on March 24 at 16:15 UTC (08:15 AKDT), removed the lava dome. The short-duration explosion showed characteristics similar to previous dome-related explosions with a very sharp onset followed by about 10 seconds of additional signal in infrasound data (fig 26). Cloud cover prevented the observation of ash cloud from this event. This explosion prompted the Aviation Color Code and Volcano Alert Level to be upgraded from YELLOW and ADVISORY to ORANGE and WATCH, respectively

On April 5, the Aviation Color Code and Volcano Alert Level was downgraded from ORANGE and WATCH to YELLOW and ADVISORY, respectively, because of inactivity since the explosion on March 24. Satellite imagery showed a new lava dome was extruded into the summit crater sometime before April 15 and by April 23 grew into a smooth 45-m- (150-ft-) diameter dome. The presence of a growing lava dome in the summit crater of Mount Cleveland prompted an Aviation Color Code and Volcano Alert Level upgrade to ORANGE and WATCH, respectively, on April 24. Extrusion of lava continued, and by April 28 three stacked domes had formed (fig. 27). The lowermost dome was $60 \times 50 \mathrm{~m}(200 \times$ $160 \mathrm{ft})$, the second dome $40 \times 30 \mathrm{~m}(130 \times 100 \mathrm{ft})$, and the newest and topmost dome was $15 \mathrm{~m}(50 \mathrm{ft})$ in diameter. The topmost circular dome continued to grow, and by May 2, it was greater than $20 \mathrm{~m}(65 \mathrm{ft})$ in diameter. Satellite imagery from May 8 showed no change in the size of the top dome, signifying that lava effusion had ceased at Mount Cleveland.

On May 17, 03:17 UTC (May 16, 19:17 AKDT), an automated infrasound alarm indicated an explosion. A continuous 
Table 6. Summary of activity and observations at Mount Cleveland in 2017.

[This table is condensed from an extensive chronology that is maintained by Alex Iezzi, University of Alaska Fairbanks Geophysical Institute and Alaska Volcano Observatory, as the chronology editor. All dates are listed in month, day, and year format and in Universal Coordinated Time. Note: Absence of data in table below is marked by -, which may indicate no change in activity, possible cloud cover obscuring ground observations in satellite imagery, no observation recorded, or no seismic or infrasound detection observed. ]

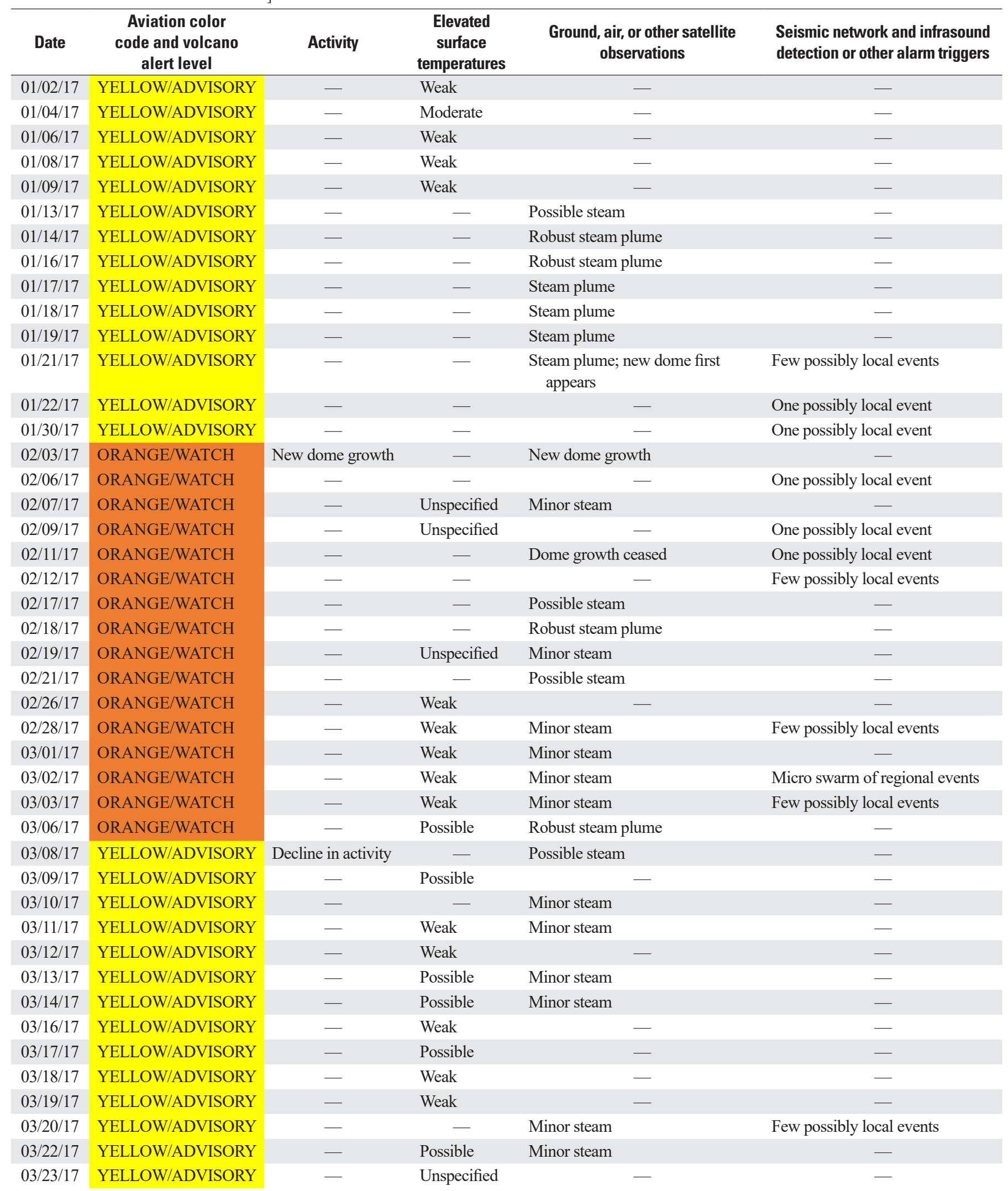


Table 6.-Continued

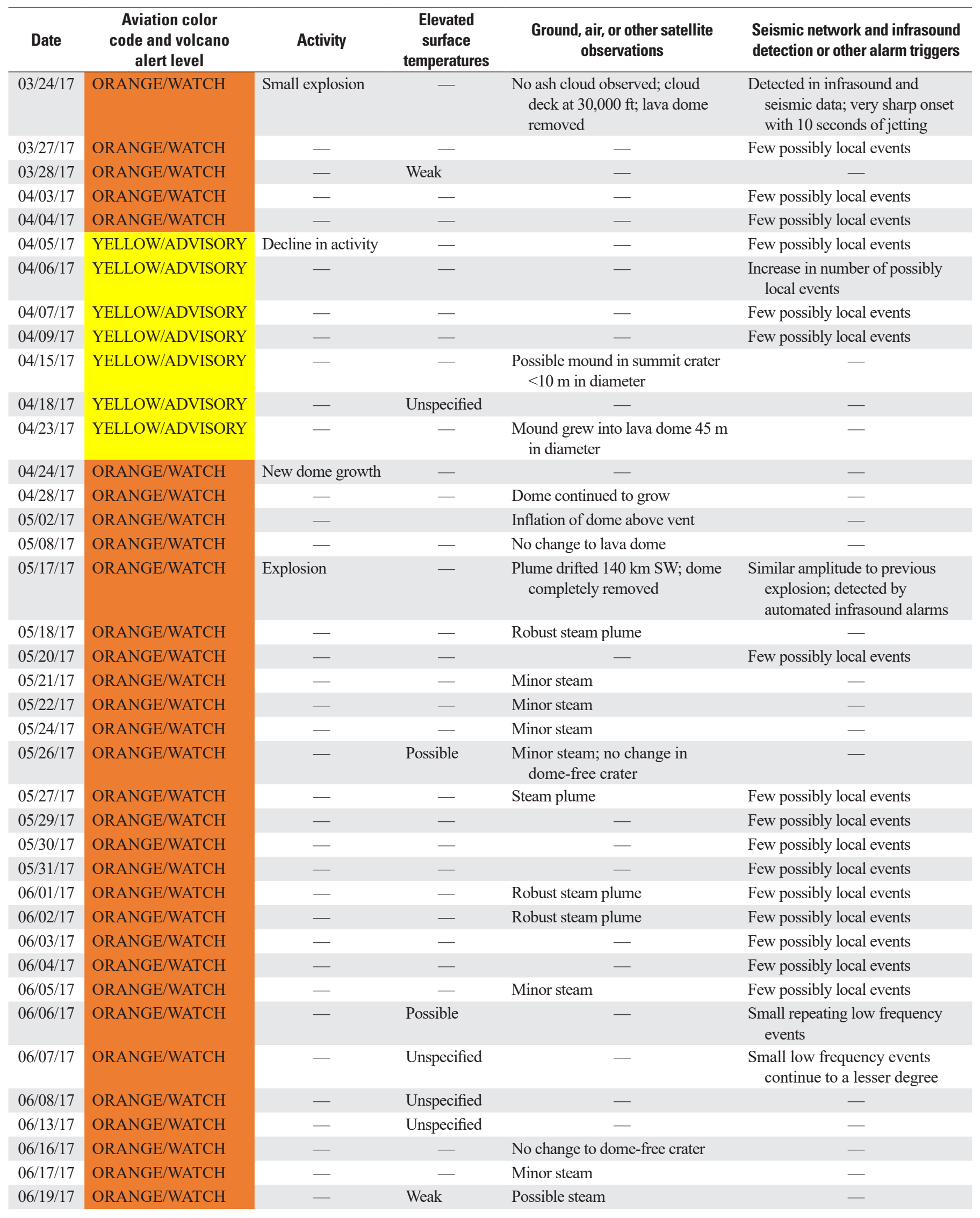


Table 6.-Continued

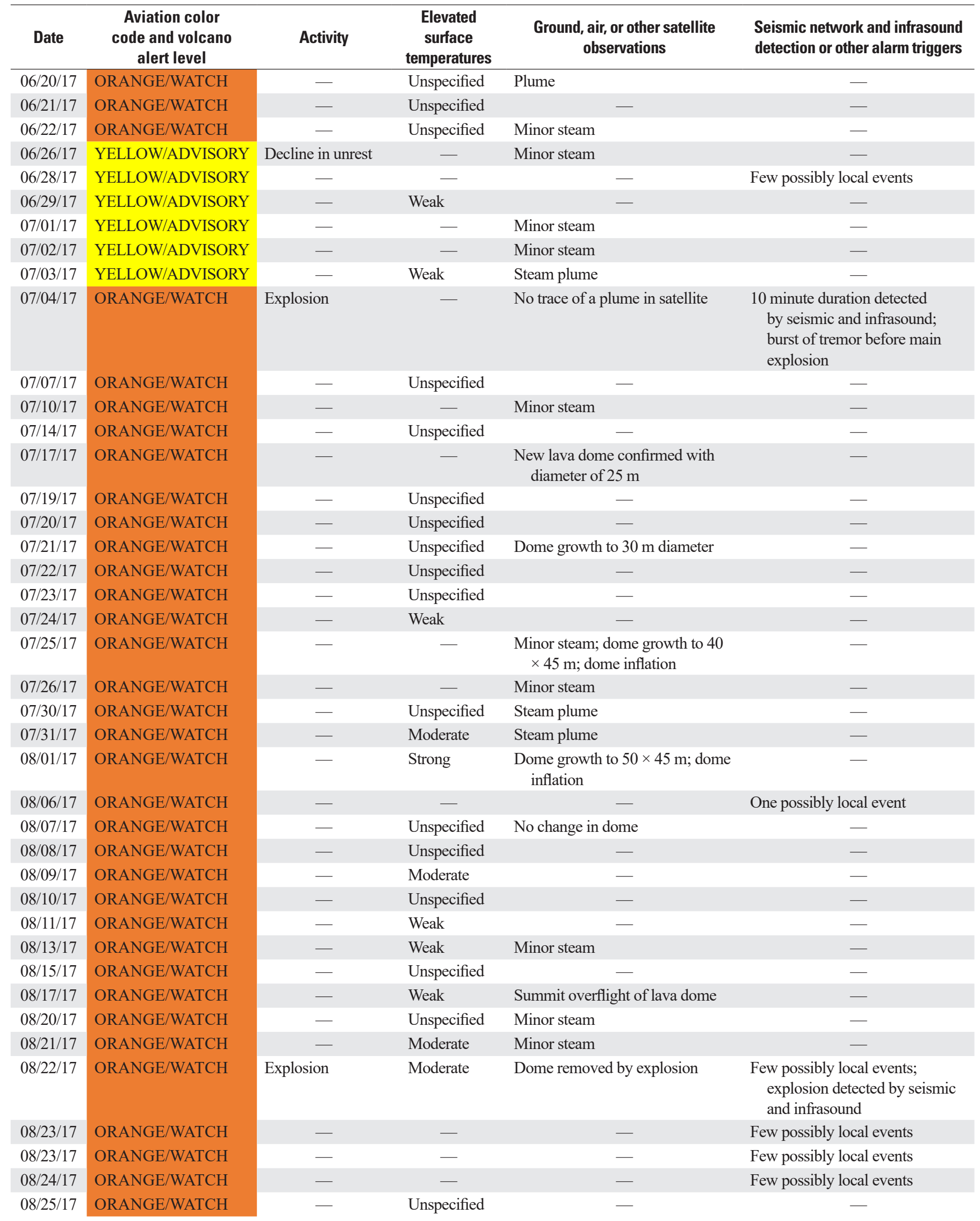


Table 6.-Continued

\begin{tabular}{|c|c|c|c|c|c|}
\hline Date & $\begin{array}{c}\text { Aviation color } \\
\text { code and volcano } \\
\text { alert level }\end{array}$ & Activity & $\begin{array}{c}\text { Elevated } \\
\text { surface } \\
\text { temperatures }\end{array}$ & $\begin{array}{l}\text { Ground, air, or other satellite } \\
\text { observations }\end{array}$ & $\begin{array}{l}\text { Seismic network and infrasound } \\
\text { detection or other alarm triggers }\end{array}$ \\
\hline $08 / 26 / 17$ & ORANGE/WATCH & - & Unspecified & - & - \\
\hline $08 / 28 / 17$ & ORANGE/WATCH & - & Unspecified & Minor steam & - \\
\hline $08 / 29 / 17$ & ORANGE/WATCH & - & - & Minor steam & - \\
\hline $09 / 05 / 17$ & ORANGE/WATCH & - & Weak & - & - \\
\hline 09/10/17 & ORANGE/WATCH & - & - & Minor steam & - \\
\hline $09 / 14 / 17$ & ORANGE/WATCH & - & Weak & Minor steam & - \\
\hline 09/17/17 & ORANGE/WATCH & - & - & Minor steam & - \\
\hline $09 / 25 / 17$ & ORANGE/WATCH & - & - & - & Few possibly local events \\
\hline $09 / 26 / 17$ & ORANGE/WATCH & Explosion & - & $\begin{array}{l}\text { Crater empty prior to explosion; } \\
\text { ash cloud }<15,000 \mathrm{ft}\end{array}$ & $\begin{array}{l}\text { 2-minute-long explosion detected } \\
\text { in seismic and infrasound data; } \\
\text { few possibly local events }\end{array}$ \\
\hline $09 / 27 / 17$ & ORANGE/WATCH & - & - & - & One possibly local event \\
\hline $09 / 28 / 17$ & ORANGE/WATCH & $\begin{array}{l}\text { Two very small } \\
\text { explosions }\end{array}$ & Unspecified & - & $\begin{array}{l}\text { Two very small explosions about } \\
100 \text { times smaller than one on } \\
9 / 26 / 17\end{array}$ \\
\hline $09 / 29 / 17$ & ORANGE/WATCH & - & - & - & Few possibly local events \\
\hline $09 / 30 / 17$ & ORANGE/WATCH & - & Unspecified & Minor steam & 一 \\
\hline $10 / 11 / 17$ & ORANGE/WATCH & - & - & $\begin{array}{l}\text { Lava dome growth to twice its } \\
\text { area; now } 115 \times 95 \mathrm{~m}\end{array}$ & - \\
\hline $10 / 15 / 17$ & ORANGE/WATCH & - & - & $\begin{array}{l}\text { Lava dome growth to } 100 \times \\
125 \mathrm{~m} \text {; dome inflation }\end{array}$ & - \\
\hline $10 / 16 / 17$ & ORANGE/WATCH & - & Moderate & Minor steam & - \\
\hline $10 / 19 / 17$ & ORANGE/WATCH & - & - & No major changes to lava dome & - \\
\hline $10 / 22 / 17$ & ORANGE/WATCH & - & Weak & Minor steam & - \\
\hline $10 / 23 / 17$ & ORANGE/WATCH & - & Moderate & Minor steam & - \\
\hline $10 / 24 / 17$ & ORANGE/WATCH & - & - & - & One possibly local event \\
\hline $10 / 27 / 17$ & ORANGE/WATCH & - & - & - & $\begin{array}{l}\text { Three local long period } \\
\text { earthquakes; no infrasound } \\
\text { associated with events }\end{array}$ \\
\hline $10 / 28 / 17$ & ORANGE/WATCH & Explosion & - & - & $\begin{array}{l}\text { 30-second-long explosion } \\
\text { detected by seismic and } \\
\text { infrasound data }\end{array}$ \\
\hline $10 / 30 / 17$ & ORANGE/WATCH & Small explosion & - & - & $\begin{array}{l}\text { Small explosion about } 4 \text { times } \\
\text { smaller than one on } 10 / 28 / 17\end{array}$ \\
\hline $10 / 31 / 17$ & ORANGE/WATCH & - & Moderate & $\begin{array}{l}\text { Recent explosions removed } \\
\text { portion of central lava dome }\end{array}$ & - \\
\hline $11 / 03 / 17$ & ORANGE/WATCH & - & Strong & - & - \\
\hline
\end{tabular}


Table 6.-Continued

\begin{tabular}{|c|c|c|c|c|c|}
\hline Date & $\begin{array}{c}\text { Aviation color } \\
\text { code and volcano } \\
\text { alert level }\end{array}$ & Activity & $\begin{array}{c}\text { Elevated } \\
\text { surface } \\
\text { temperatures }\end{array}$ & $\begin{array}{c}\text { Ground, air, or other satellite } \\
\text { observations }\end{array}$ & $\begin{array}{l}\text { Seismic network and infrasound } \\
\text { detection or other alarm triggers }\end{array}$ \\
\hline $11 / 05 / 17$ & ORANGE/WATCH & - & Weak & - & - \\
\hline $11 / 06 / 17$ & ORANGE/WATCH & - & Unspecified & - & - \\
\hline $11 / 07 / 17$ & ORANGE/WATCH & - & Moderate & - & - \\
\hline $11 / 08 / 17$ & ORANGE/WATCH & - & Unspecified & - & - \\
\hline $11 / 09 / 17$ & ORANGE/WATCH & - & Unspecified & - & - \\
\hline $11 / 11 / 17$ & ORANGE/WATCH & - & Unspecified & - & - \\
\hline $11 / 12 / 17$ & ORANGE/WATCH & $\begin{array}{l}\text { Very small } \\
\quad \text { explosion }\end{array}$ & - & - & $\begin{array}{l}\text { Very small explosion seen in loca } \\
\text { seismic and infrasound data }\end{array}$ \\
\hline $11 / 13 / 17$ & ORANGE/WATCH & - & Moderate & - & - \\
\hline $11 / 14 / 17$ & ORANGE/WATCH & Small explosion & Moderate & - & $\begin{array}{l}\text { Small explosion detected with } \\
\text { two local earthquakes } 1 \text { hour } \\
\text { prior }\end{array}$ \\
\hline $11 / 16 / 17$ & ORANGE/WATCH & Small explosion & Weak & $\begin{array}{l}\text { Possible small amount of ash } \\
\text { emissions }\end{array}$ & $\begin{array}{l}\text { Small explosion similar to size on } \\
11 / 14 / 17\end{array}$ \\
\hline $11 / 17 / 17$ & ORANGE/WATCH & - & - & - & Small earthquake swarm \\
\hline $11 / 30 / 17$ & ORANGE/WATCH & - & - & - & Few possibly local events \\
\hline $12 / 01 / 17$ & ORANGE/WATCH & - & - & - & Few possibly local events \\
\hline $12 / 03 / 17$ & ORANGE/WATCH & - & - & - & Few Possibly Local Events \\
\hline $12 / 04 / 17$ & ORANGE/WATCH & Small explosion & - & - & $\begin{array}{l}\text { Small explosion only detected on } \\
\text { closest station CLES }\end{array}$ \\
\hline $12 / 12 / 17$ & YELLOW/ADVISORY & Decline in activity & - & - & - \\
\hline $12 / 13 / 17$ & ORANGE/WATCH & Explosion & - & Ash cloud drifted east & $\begin{array}{l}\text { Explosion detected by seismic } \\
\text { and infrasound data }\end{array}$ \\
\hline $12 / 18 / 17$ & ORANGE/WATCH & Small explosion & - & - & $\begin{array}{l}\text { Small explosion detected about } \\
\text { four times smaller than event } \\
\text { on } 12 / 13 / 17\end{array}$ \\
\hline $12 / 24 / 17$ & ORANGE/WATCH & - & - & - & Few possibly local events \\
\hline $12 / 25 / 17$ & ORANGE/WATCH & - & - & - & Few possibly local events \\
\hline $12 / 26 / 17$ & ORANGE/WATCH & - & Unspecified & - & Few possibly local events \\
\hline $12 / 29 / 17$ & ORANGE/WATCH & - & - & - & Few possibly local events \\
\hline $12 / 31 / 17$ & ORANGE/WATCH & - & Weak & - & - \\
\hline
\end{tabular}

broadband signal was recorded clearly in seismograph data and was also seen in infrasound data at stations CLES and CLCO for 10 minutes after the initial explosion. The extended infrasound signals were likely caused by jetting (continuous, vigorous gas emissions) after the destruction of the lava dome in the vent. The resulting ash plume drifted approximately $140 \mathrm{~km}(87 \mathrm{mi})$ to the southwest at an altitude of $4.6 \mathrm{~km}(15,000 \mathrm{ft})$ and was observed in visible Geostationary Operational Environmental Satellite imagery until nightfall. Satellite imagery just after the explosion showed that the dome was completely removed, and impact craters from ballistic dome fragments were formed on the upper flanks of the volcano. The Mount Cleveland summit crater was dome free through May 26.

On June 6, a series of repeating small low-frequency seismic events were recorded on seismograph station CLES, $3.5 \mathrm{~km}(2.1 \mathrm{mi})$ from the summit, but these events were not seen on nearby seismograph station CLCO, $15 \mathrm{~km}$ (9 mi) from the summit. The seismicity was consistent with lava dome growth, but poor viewing conditions prevented the confirmation of dome growth. On June 26, the Aviation Color Code and Volcano Alert Level was reduced from ORANGE and WATCH to YELLOW and ADVISORY, respectively, owing to the decline in activity.

On July 4, 11:19 UTC (03:19 AKDT), a moderate 10-minute eruption was detected by both seismograph and infrasound sensors, prompting the Aviation Color Code and Volcano Alert Level to be upgraded from YELLOW and ADVISORY to ORANGE and WATCH, respectively. This explosion differed from the previous explosion by being preceded by at least five low-frequency seismic events. Additionally, a burst of tremor was recorded 15 seconds prior to the onset of the main explosion (fig. 28). 

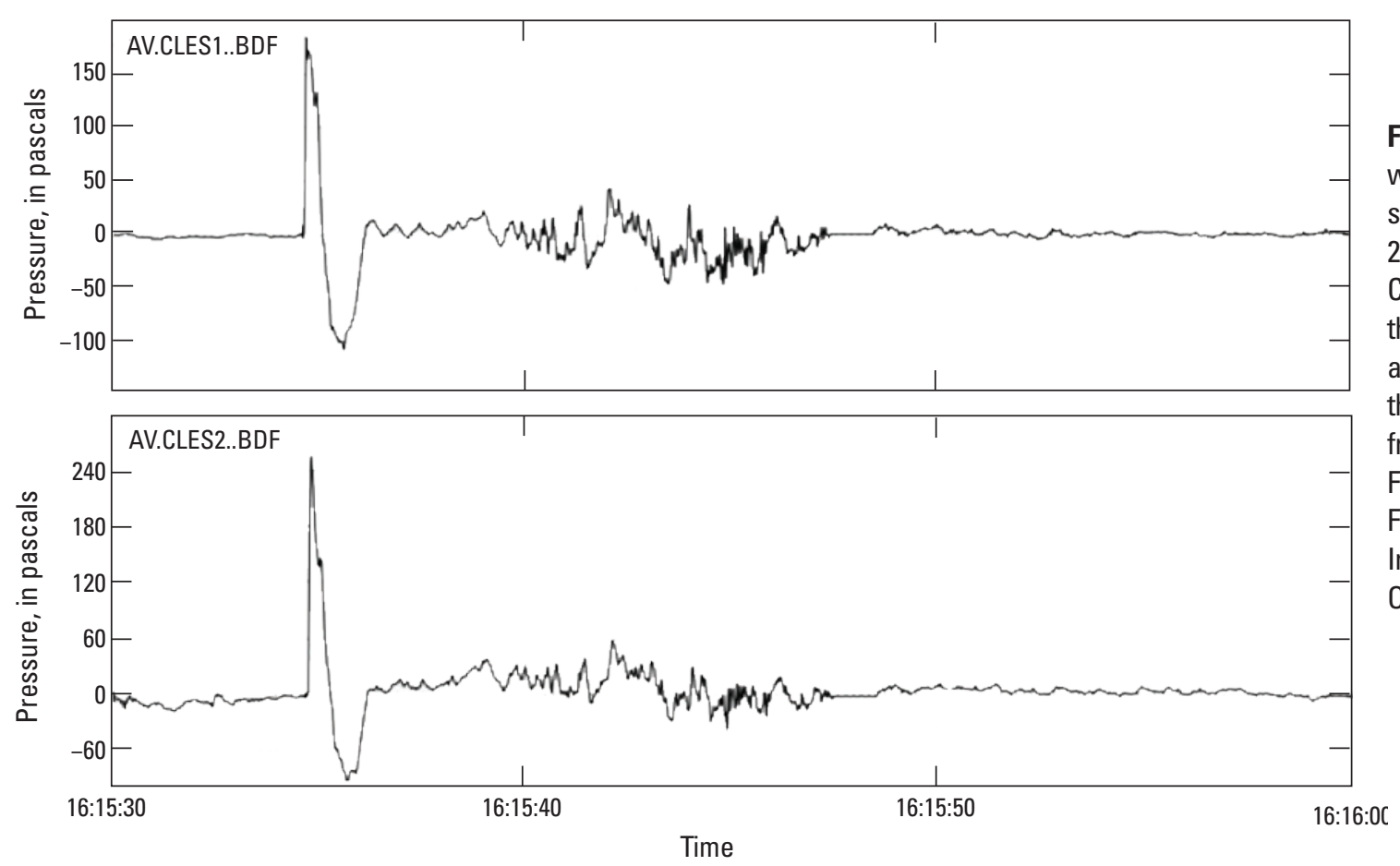

Figure 26. Infrasound waveform graphs showing the March 24, 2017, explosion of Mount Cleveland volcano at the station CLES located about $3.5 \mathrm{~km}(2.1 \mathrm{mi})$ from the summit. Modified from image by David Fee, University of Alaska Fairbanks Geophysical Institute-Alaska Volcano Observatory.

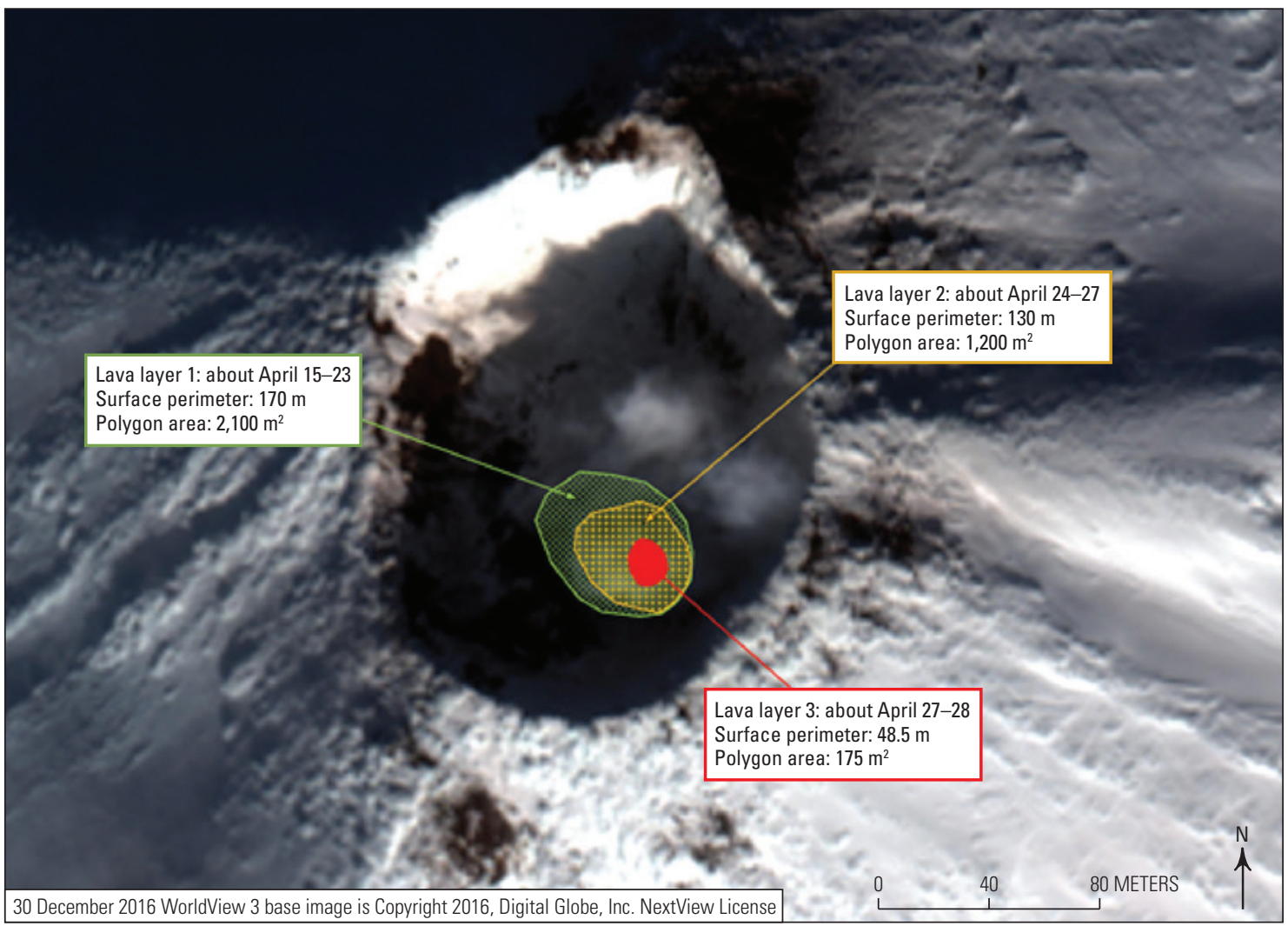

Figure 27. Worldview3 satellite base image and digital sketches of the three lava domes in Mount Cleveland's summit crater from April 15 to 28, 2017. Lava layer 1 represents the lowermost lava dome that formed about April 15-23. Lava layer 2 represents the second lava dome that formed about April 24-27. Lava layer 3 represents the topmost lava dome that formed about April 27-28. Modified from image by Rick Wessels, U.S. Geological Survey and Alaska Volcano Observatory. 

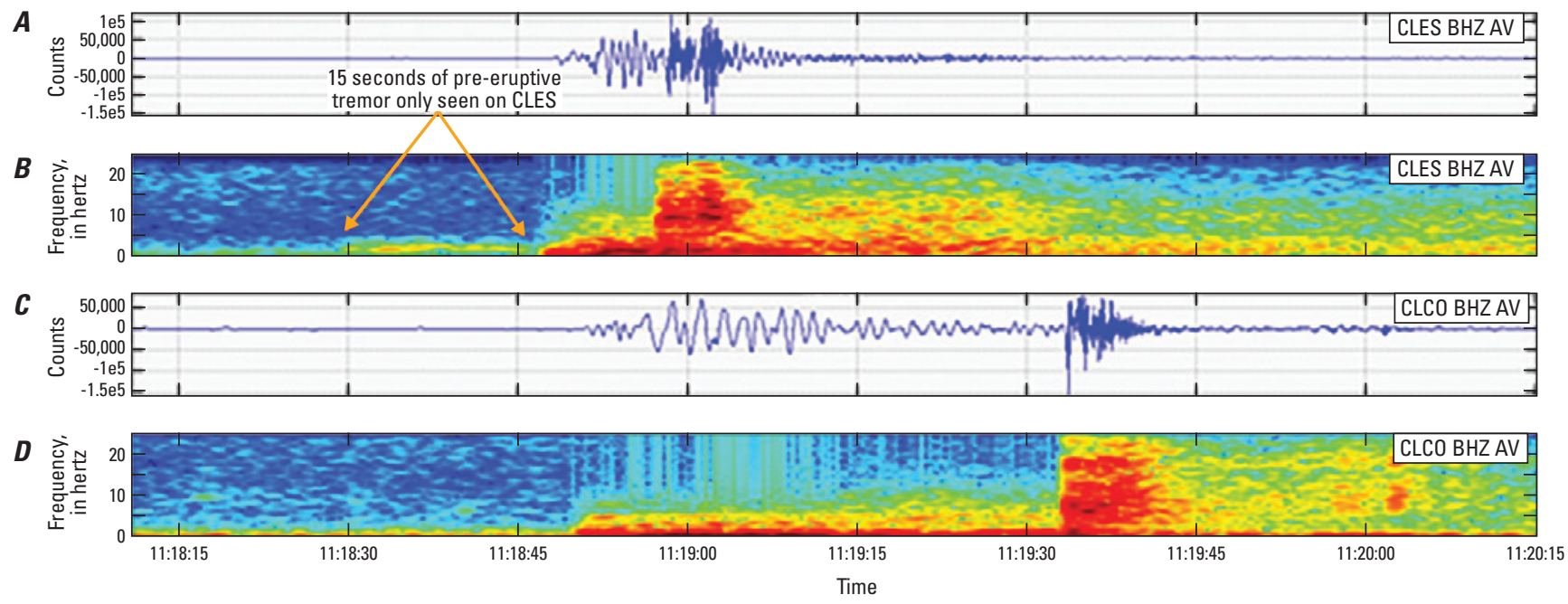

Figure 28. Seismic waveform $(A$ and $C$ ) and spectrogram graphs ( $B$ and $D$ ) showing the July 4, 2017, explosion of Mount Cleveland. Arrows point to the 15 -second duration of pre-eruptive tremor seen on station CLES. Stations CLES and CLCO are $3.5 \mathrm{~km}$ (2.1 mi) and $15.4 \mathrm{~km}$ (9.2 mi) away from Mount Cleveland, respectively. Modified from image by John Lyons, U.S. Geological Survey-Alaska Volcano Observatory.

Satellite data from July 17 show that a new 25-m- (80-ft-) diameter lava dome was emplaced in the summit crater. It grew to more than $50 \mathrm{~m}(160 \mathrm{ft})$ in diameter with increased vertical inflation by August 1. Satellite imagery on August 7 showed no change in the lava dome from the previous satellite images, signifying that lava effusion had ceased. This small lava dome was observed by an AVO field crew during an overflight of Mount Cleveland on August 17 (fig. 29).

The fourth explosion in 2017 occurred on August 22 at 18:43 UTC (10:43 AKDT). The oneminute explosion had no precursory activity and was detected by both seismograph and infrasound sensors. Satellite imagery suggested that this explosion, like the previous three eruptions, removed the existing lava dome. The crater remained empty for more than a month until another explosion occurred on September 26, 01:47 UTC (September 25, 17:47 AKDT). The initial blast lasted 3 seconds, but after a brief 15 -second pause, a roughly 2-minute-long broadband signal was detected in both seismic and infrasound data suggesting an initial vulcanian blast that was followed by continuous emissions (fig. 30). An ash cloud was visible in a NOAA-19 satellite image south of Mount Cleveland for 30 minutes after the explosion.

Figure 29. Photograph of a small lava dome in the summit crater of Mount Cleveland volcano on August 17, 2017, taken by Janet Schaefer (Alaska Division of Geological \& Geophysical Surveys and Alaska Volcano Observatory) during a summit overflight.

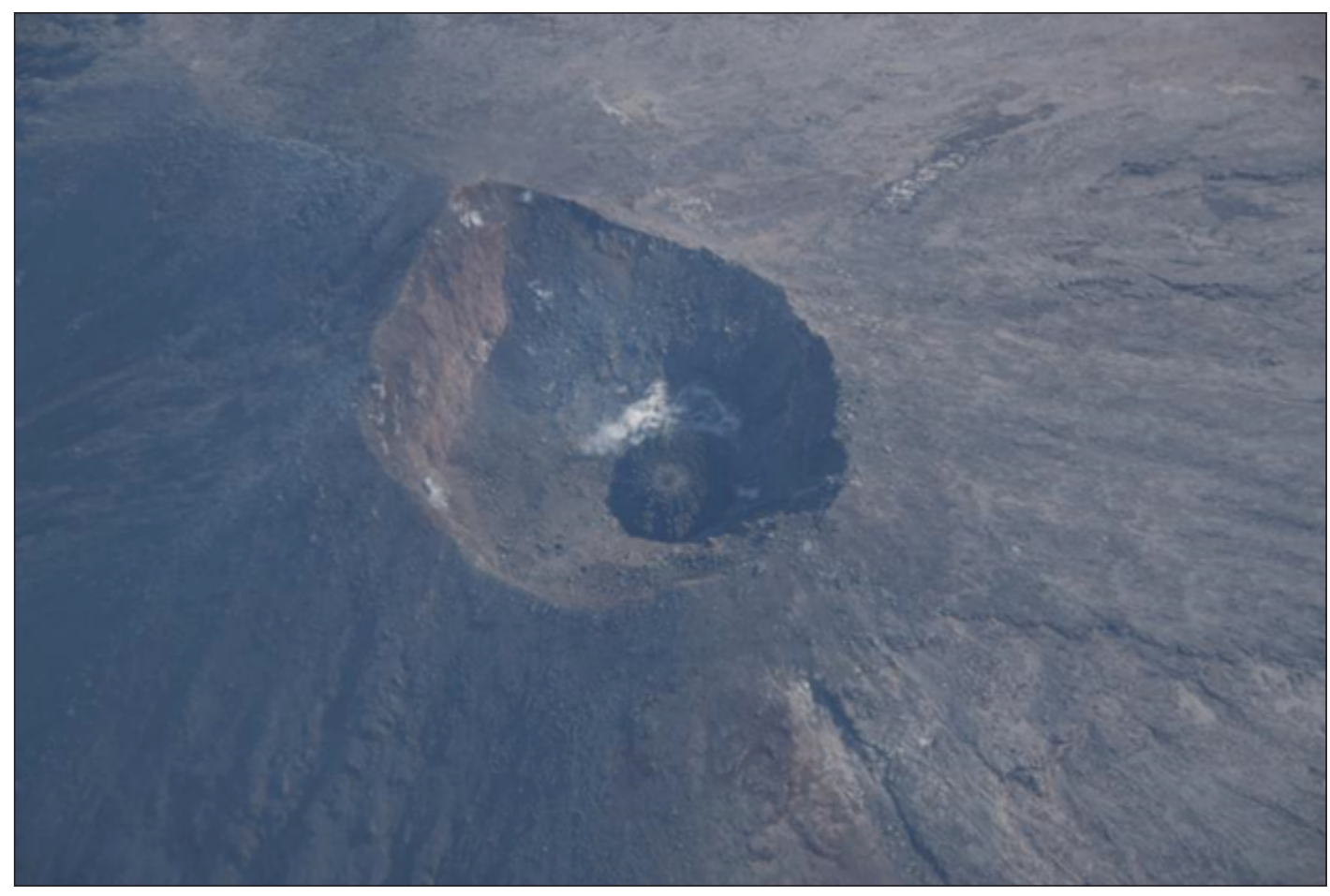



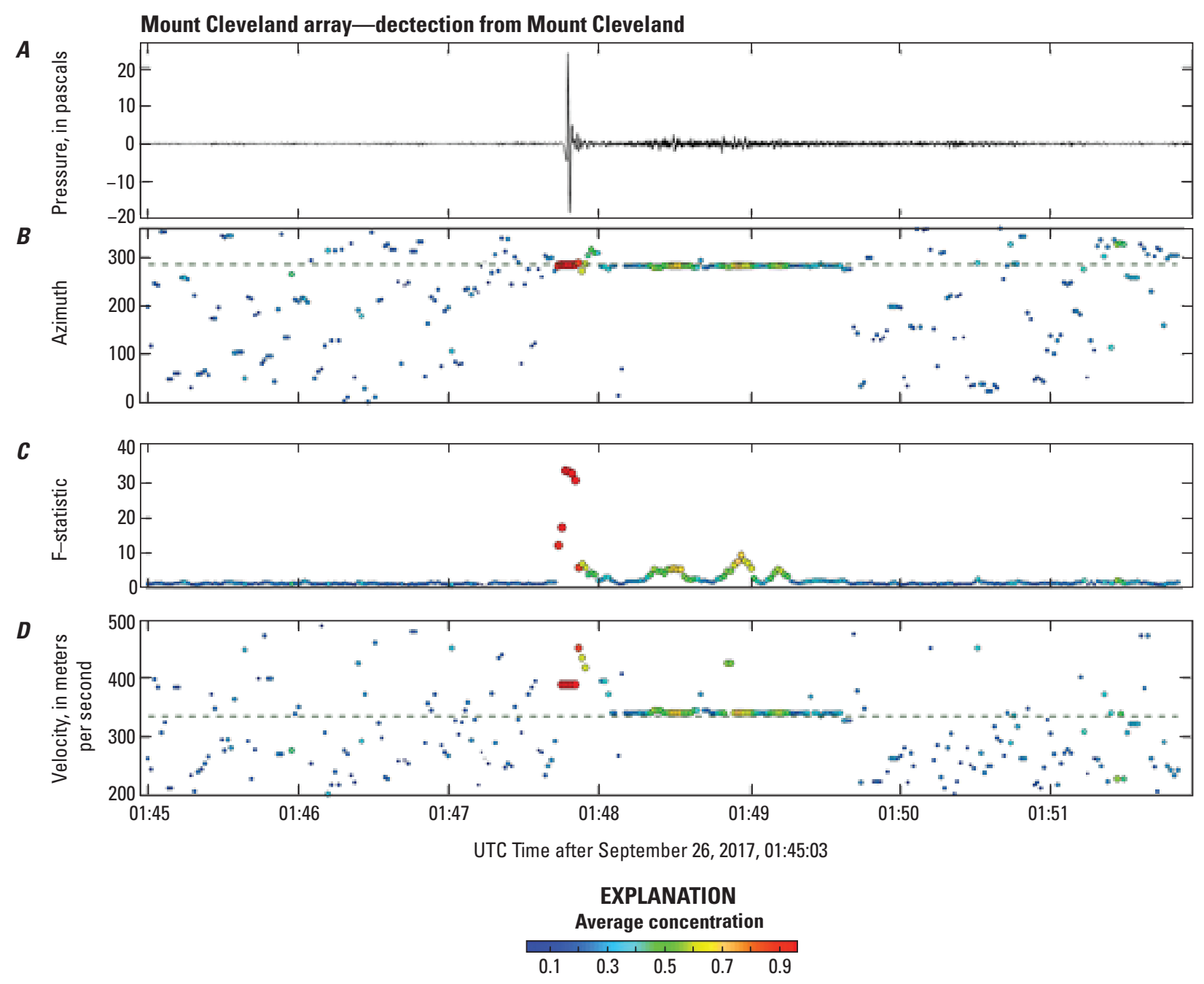

Figure 30. Several graphs of processed data from the station CLCO infrasound array for the September 26, 2017, Mount Cleveland explosion showing an initial blast followed by a brief pause and 2 minutes of jetting. $A$, Simple pressure plot showing when the explosion occurred. $B$, Plot showing the azimuth of the signal with respect to station CLCO. C, Plot showing the F-statistic, which is an algorithm for detecting explosion signals above the noise. $D$, Plot showing the velocity of the signal. Modified from image by John Lyons, U.S. Geological Survey and Alaska Volcano Observatory.

The explosions later in 2017 were smaller and more frequent than those at the beginning of the year. Two small explosions occurred on September 28 at 13:19 and 13:58 UTC (05:19 and 05:58 AKDT, respectively) with amplitudes approximately 100 times smaller than the explosion 2 days prior. Another small explosion occurred on October 1, at 13:05 UTC (05:05 AKDT).

Satellite observations on October 1 showed a new lava dome greater than $70 \mathrm{~m}(230 \mathrm{ft})$ in diameter, and by October 15, the dome had doubled in area to cover 12,500 square meters $\left(\mathrm{m}^{2} ; 134,500\right.$ square feet $\left.\left[\mathrm{ft}^{2}\right]\right)$ at a height of $15-20 \mathrm{~m}(50-65 \mathrm{ft})$. The dome continued to increase in both area and height through October 23. On October 28, a small, short-duration (30 sec) explosion occurred at 18:45 UTC (10:45 AKDT). A smaller explosion occurred on October 30 at 11:20 UTC (03:20 AKDT).
Satellite imagery suggests that the October explosions removed a portion of the central vent from the dome. A small explosion occurred on November 12 at 09:56 UTC (00:56 AKST) followed by a similar-sized explosion on November 14 at 12:15 UTC (03:15 AKST). The latter event was preceded by two local earthquakes 1 hour prior to the explosion. Another small explosion occurred on November 16 at 22:44 UTC (13:44 AKST) that was similar to the previous events. Between November 17, 22:00 UTC (13:00 AKST) and November 18, 08:20 UTC (November 17, 23:20 AKST), a small volcanic-tectonic earthquake swarm occurred in the vicinity of Mount Cleveland, but its significance to the Mount Cleveland eruption sequence has yet to be determined. A small explosion occurred on December 4, 07:21 UTC (December 3, 22:21 AKST) that was seen just at the closest seismograph station to the summit (CLES). 
Decreased activity following the December 4, 2017, explosion was interpreted as cessation of lava effusion at Mount Cleveland, which prompted AVO to change the Aviation Color Code and Volcano Alert Level from ORANGE and WATCH to YELLOW and ADVISORY, respectively, on December 12. However, less than a day later, another explosion occurred on December 13 at 13:20 UTC (04:20 AKST) necessitating that the Aviation Color Code and Volcano Alert Level to be returned to ORANGE and WATCH, respectively. The ash cloud from this eruptive event was visible in satellite imagery and drifted east at an altitude of $6.1 \mathrm{~km}$ (20,000 ft; fig. 31). The final explosion of 2017 occurred on December 18 at 03:17 UTC (December 17, 18:17 AKST), and like recent explosions was smaller than the explosions in early 2017. The Aviation Color Code and Volcano Alert Level remained at ORANGE and WATCH, respectively, for the remainder of the year.

Mount Cleveland volcano forms the west part of Chuginadak Island, an uninhabited island in the Islands of the Four Mountains group in the east-central Aleutian Islands. Mount Cleveland is located about $75 \mathrm{~km} \mathrm{(45} \mathrm{mi)} \mathrm{west} \mathrm{of} \mathrm{the} \mathrm{com-}$ munity of Nikolski, Alaska. Short-lived ash explosions, lava fountaining, lava flows, and pyroclastic avalanches down the flanks of the volcano have characterized historical eruptions. In February 2001, after 6 years of quiescence, Mount Cleveland had three explosive events that produced ash clouds as high as $12 \mathrm{~km}$ (39,000 ft; Dean and others, 2004), a rubbly lava flow, and hot avalanche that reached the sea. Intermittent explosive eruptions have occurred every year since 2001 .

\section{Great Sitkin Volcano}

GVP\# 311120

$52.0765^{\circ} \mathrm{N} ., 176.1109^{\circ} \mathrm{W}$.

$1,740 \mathrm{~m}(5,709 \mathrm{ft})$

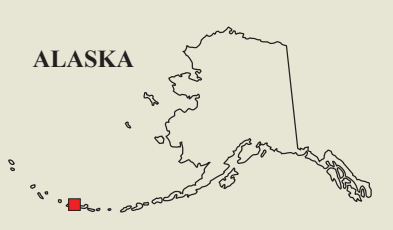

Great Sitkin Island, Andreanof Islands, Aleutian Islands

\section{EARTHQUAKE SWARM, EXPLOSION}

Between late July 2016 and January 2018 Great Sitkin Volcano experienced increased earthquake activity, anomalous gas emissions from the summit crater, and two apparent small phreatic explosions that occurred on January 11 and July 22, 2017. These were the first two explosions detected at Great Sitkin Volcano since monitoring began in 1999. Earthquake hypocenters in 2017 were chiefly clustered beneath the summit crater and ranged in depth from the surface to $10 \mathrm{~km}$, although some events were located at depths as great as $35 \mathrm{~km}$. Earthquake magnitudes ranged from $\mathrm{M}_{\mathrm{L}}=-1.5$ to 2.83 , although most events had magnitudes less than zero. The magnitude 2.8 occurred on September 29 at a depth of $1.5 \mathrm{~km}$ under the west flank of Great Sitkin Island (fig. 32).

On July 30, 2016, a marked increase in earthquake activity began at Great Sitkin Volcano that continued through early August. These earthquakes appeared to have initiated at depths of 15 to $18 \mathrm{~km}$ and then were followed within 12 hours by earthquakes with hypocenters shallower than $4 \mathrm{~km}(2.5 \mathrm{mi})$
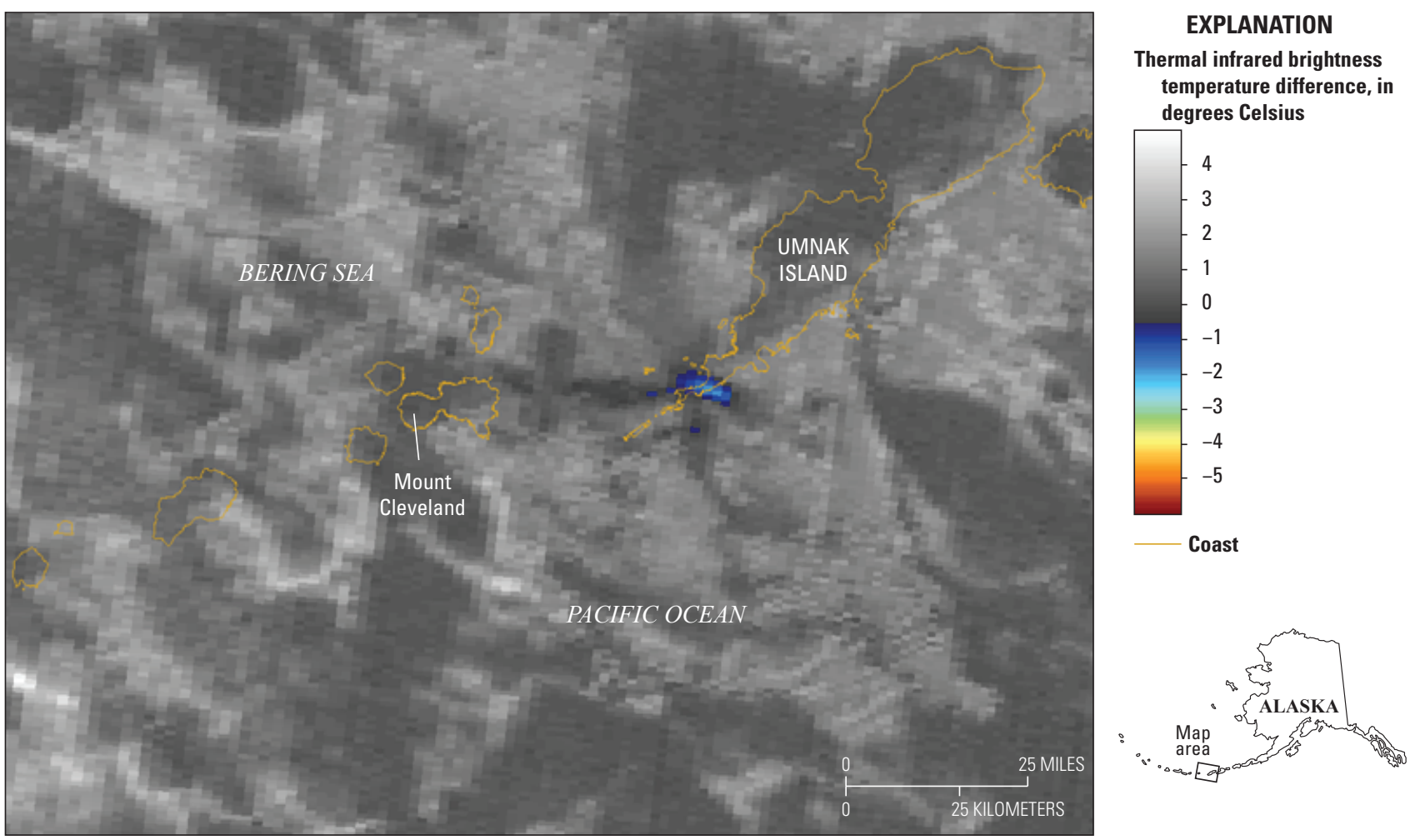

Figure 31. NOAA-19 thermal infrared brightness temperature difference image showing the December 13, 2017, eruption cloud drifting east (blue pixels) from Mount Cleveland. Modified from image by Tim Orr, U.S. Geological Survey and Alaska Volcano Observatory. 


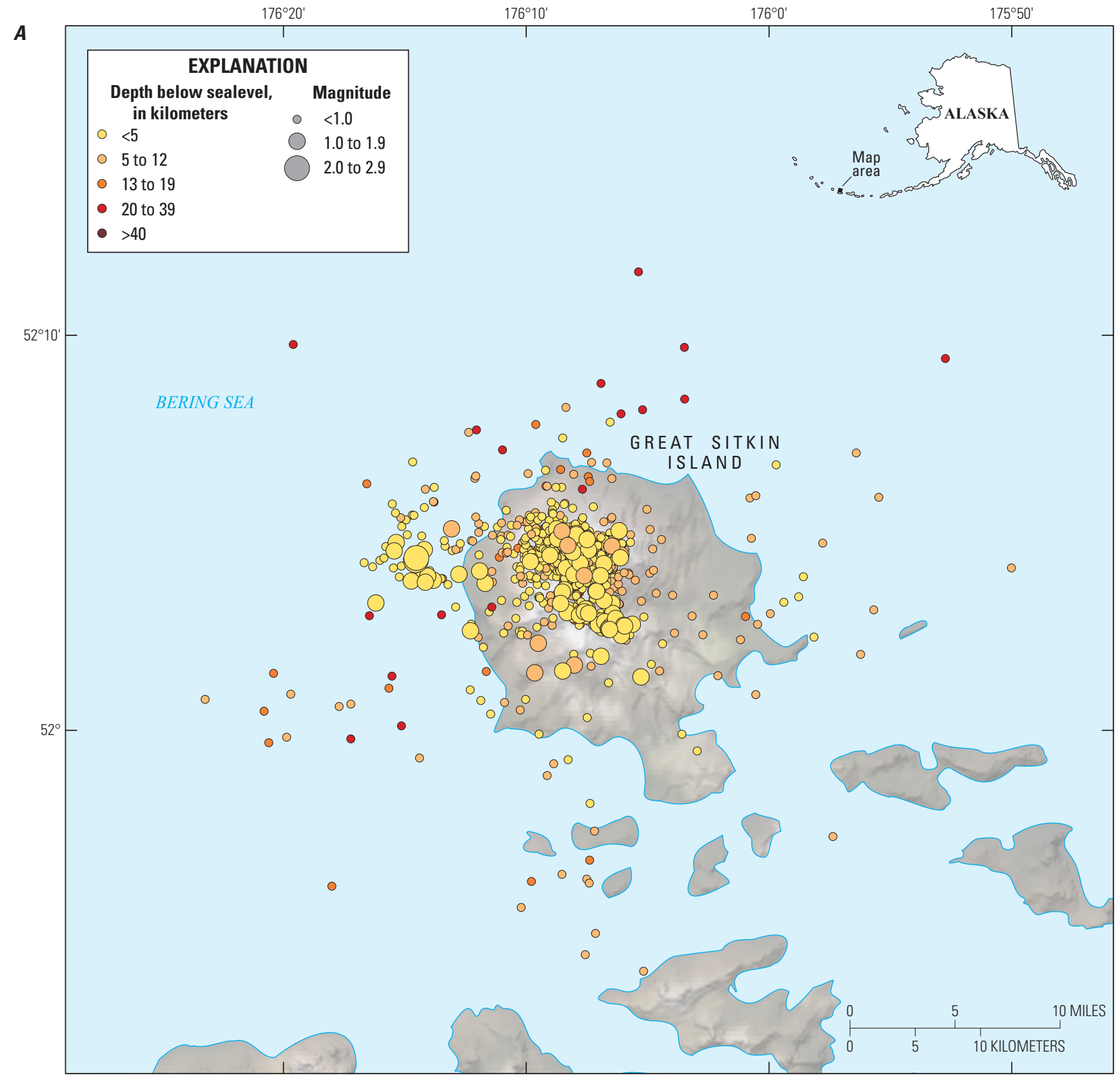

Base from U.S. Geological Survey 60-meter digital data and Alaska statewide imagery from GeoNorth Coordinate system: WGS 1984 Web Mercator Auxiliary Sphere

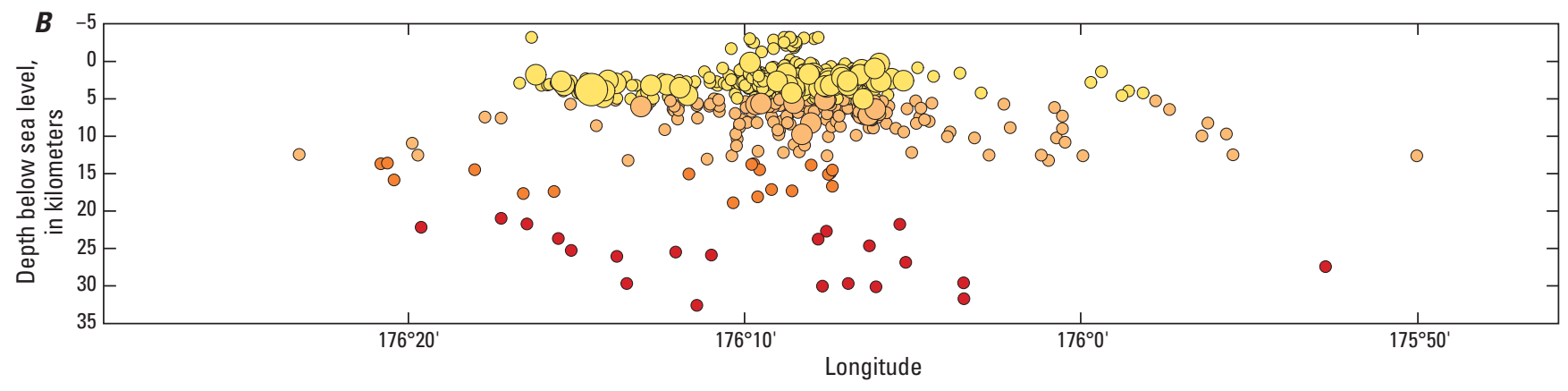

Figure 32. Map $(A)$ and graph $(B)$ of Great Sitkin Volcano showing earthquakes located in 2016 and 2017. The largest earthquake in this period, a $\mathrm{M}_{\mathrm{L}}=2.8$ on September 29, 2017, occurred off the west flank of Great Sitkin Island. 
depth (fig. 33). The deeper earthquakes on July 30 had a variety of waveform characteristics that range from broad-spectrum volcanic-tectonic earthquakes to low-frequency or long-period waveforms with extended codas suggesting that some were deep long-period (DLP) events (fig. 34). DLP earthquakes often indicate magma movement at depth and have been interpreted as recharge of shallow magma reservoirs (Power and others, 2004). After August 8, earthquake activity returned to background levels through the remainder of 2016.

On January 11, 2017, at 06:05 UTC (January 10, 21:05 AKST) a seismic signal with a high amplitude onset and an extended coda that contained numerous small earthquakes was observed only by stations on Great Sitkin Island (fig. 34). This event was interpreted as a small explosion despite the lack of confirming satellite imagery showing a gas or ash plume and detected associated infrasound signal. This event was followed by approximately 20 small $\left(\mathrm{M}_{\mathrm{L}}<0.2\right)$ locatable earthquakes beneath the northwest flank of Great Sitkin Volcano with depths ranging from the summit crater to $8.1 \mathrm{~km}(4.9 \mathrm{mi})$. After this small earthquake swarm, there was relative seismic quiescence until mid-March when small earthquakes resumed beneath the Great Sitkin Volcano summit crater at depths of 3 to $11 \mathrm{~km}$ (1.8 to $6.6 \mathrm{mi})$. This activity continued until late April (fig. 35).

In early June, shallow earthquake activity began a slow increase that continued until an explosive event at 00:17 UTC on July 22 (July 21, 16:17 AKDT). This event had an emergent onset, and the signal slowly increased until it clipped the maximum amplitude of the sensor after 6 minutes (fig. 36). Like the January explosion, this event did not produce a detectable ash plume visible in satellite imagery or a detectable infrasound signal. In response to increased unrest at Great Sitkin Volcano AVO issued an Information Statement describing the activity on July 27 but retained the Aviation Color Code and Volcano Alert Level at GREEN and NORMAL, respectively. After the July 22 explosion, seismicity remained elevated until mid-November (fig. 33).

On November 19, 2017, increased gas emissions from the volcano's summit crater was easily visible from the town of Adak, Alaska, and AVO received reports and photographs from concerned citizens, $42 \mathrm{~km}$ (26 mi) to the southwest (fig. 37). On November 22, after observations of increased degassing, AVO

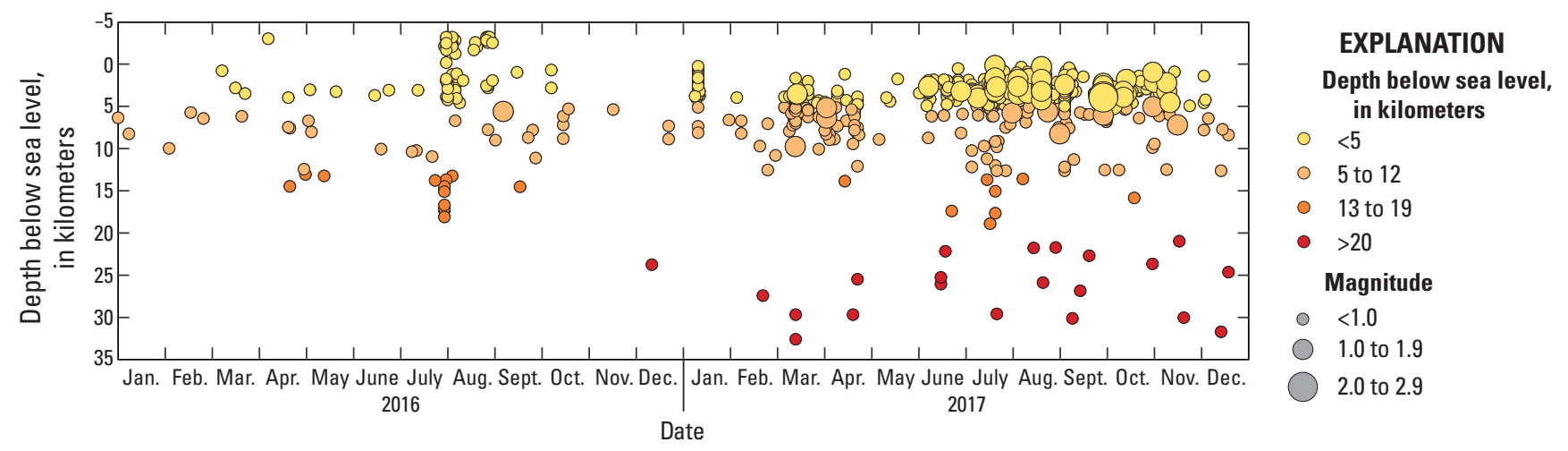

Figure 33. Plot showing earthquake focal depth versus time for January 1, 2016, through December 31, 2017, on Great Sitkin Volcano.
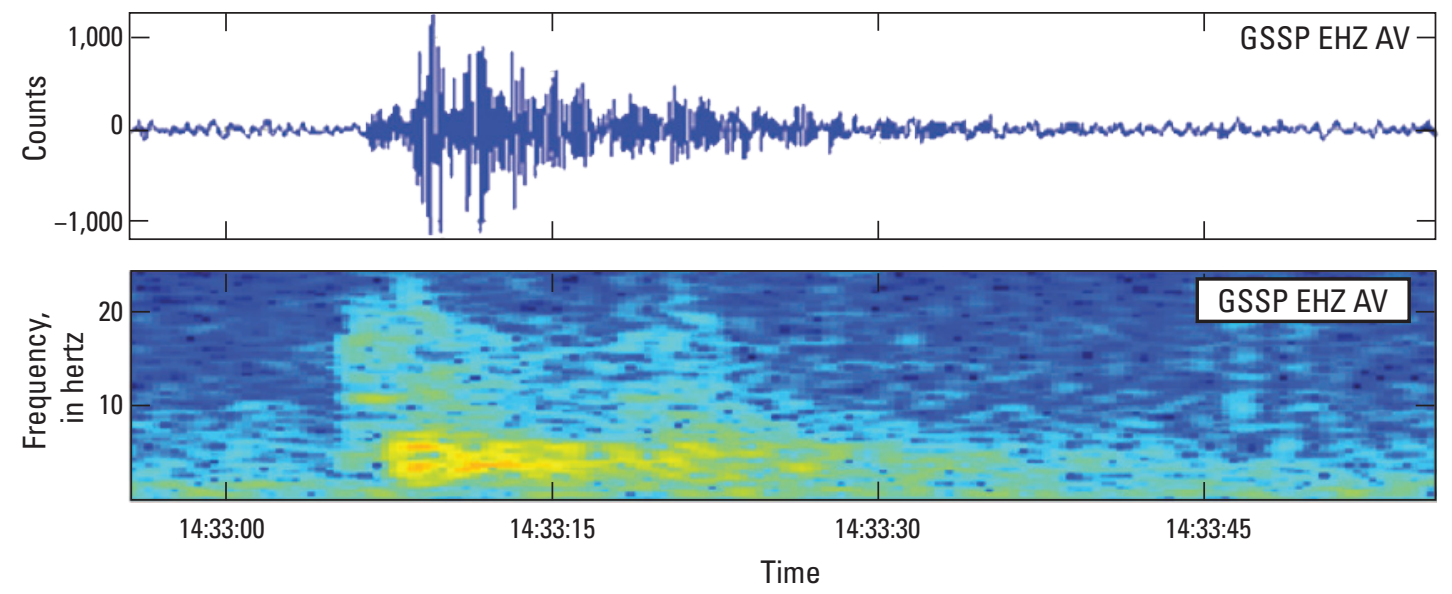

Figure 34. Waveform and spectrogram showing a magnitude -0.40 deep long-period event located under the north flank of Great Sitkin Volcano at 14:53 UTC on July 30, 2016, at a depth of $16.7 \mathrm{~km}$. 
January 11

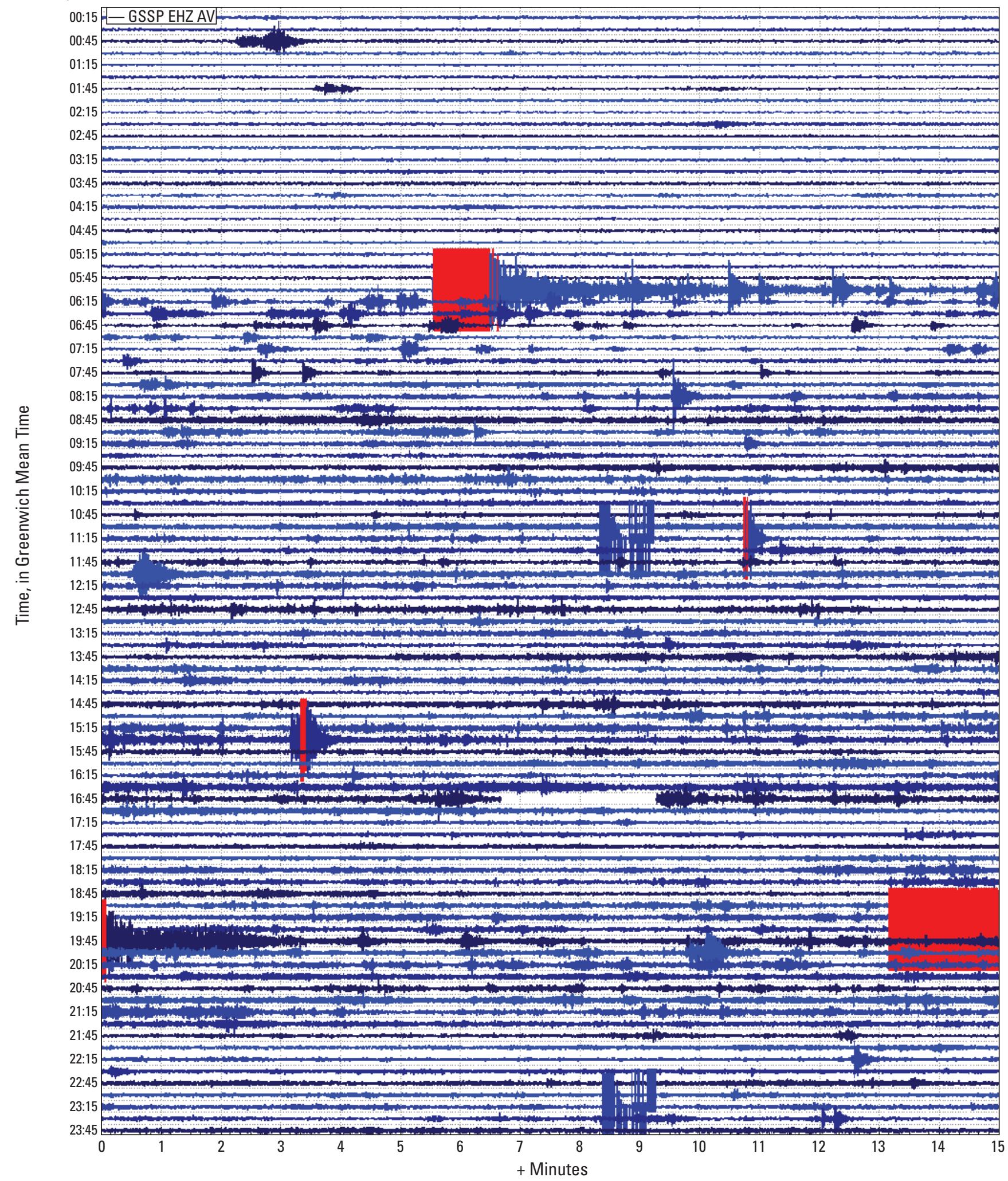

Figure 35. Seismogram of seismograph station GSSP on January 11, 2017. Suspected explosion occurs at 06:05 UTC (January 10, 221:05 AKST). 


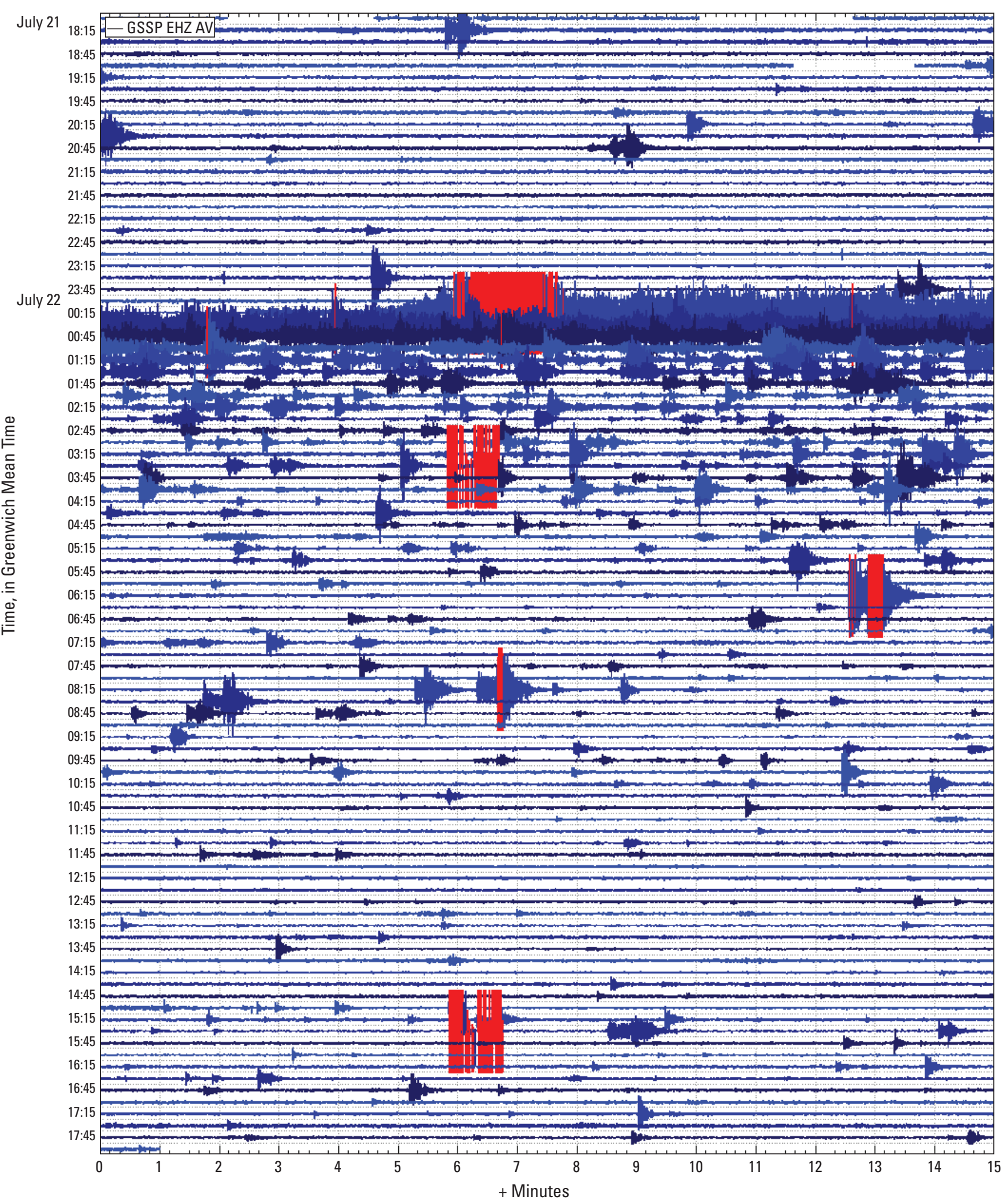

Figure 36. Seismogram of seismograph station GSSP showing 24-hours of data starting at 18:00 UTC (08:00 AKDT) on July 21, 2017. Suspected explosions begin at 00:17 UTC (July 22, 16:17 AKDT) and are followed by numerous small earthquakes. 


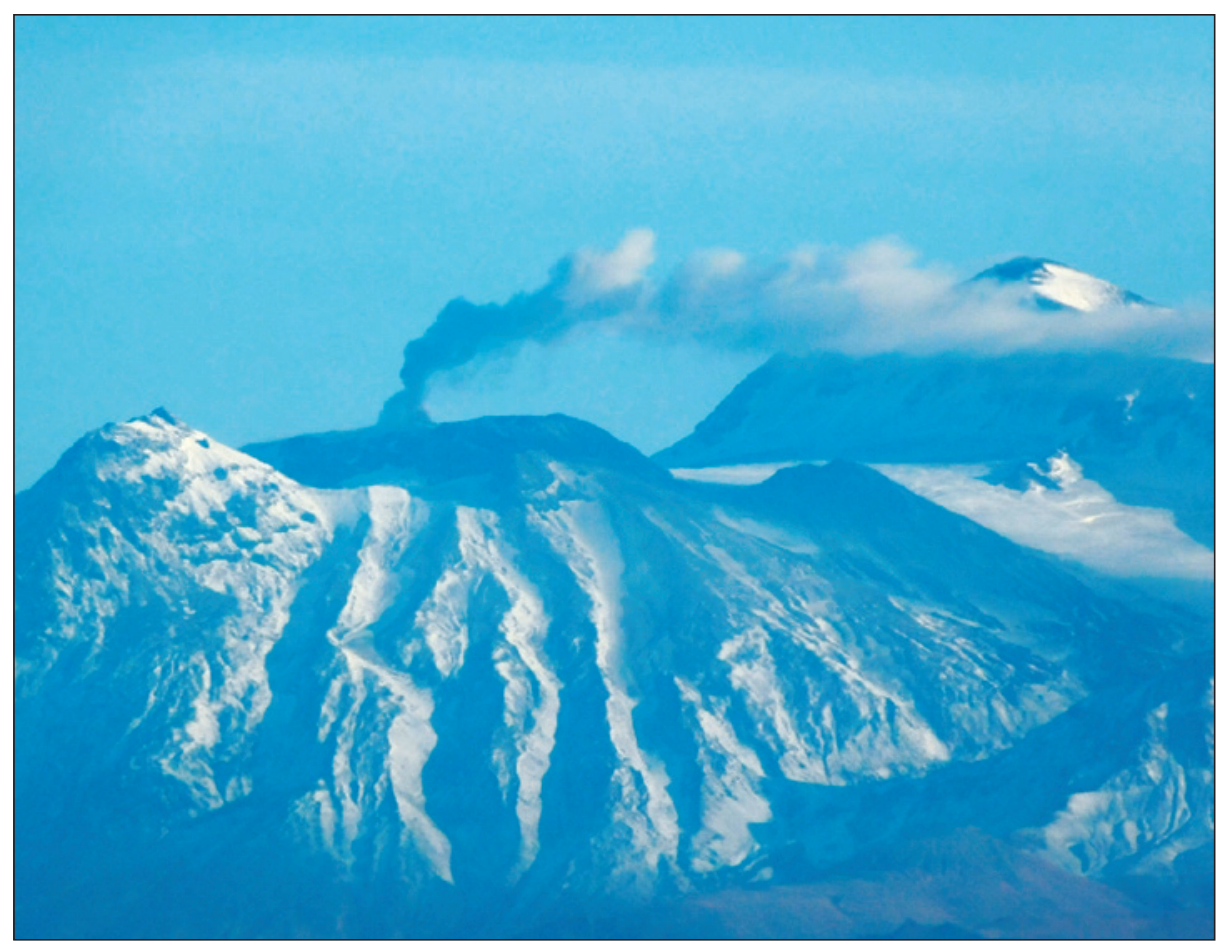

Figure 37. Photograph of Great Sitkin Volcano as seen from Adak, Alaska, $42 \mathrm{~km} \mathrm{(26} \mathrm{mi)} \mathrm{to}$ the southwest, showing gas plume from the summit crater on November 19, 2017. Photograph by Alain Beauparlant.

raised the Aviation Color Code to YELLOW and Volcano Alert Level to ADVISORY. Unrest characterized by increased crustal seismicity, degassing, and small explosive events continued into 2018. When the activity returned to background levels, the Aviation Color Code and Volcano Alert Level were lowered to GREEN and NORMAL, respectively, on January 18, 2018.

Great Sitkin Volcano is a basaltic-andesite volcano that constitutes most of the north half of Great Sitkin Island in the Andreanof Islands group of the central Aleutian Islands (Waythomas and others, 2003). The volcano consists of an older collapsed volcano and a younger parasitic cone with a 2-3-km- (1.2-1.8-mi-) diameter summit crater. A steep-sided dome occupies the center of the crater. Great Sitkin Volcano erupted at least three times in the $20^{\text {th }}$ century and most recently with a small phreatic eruption in 2018. In 1974, a lava dome formed in the crater accompanied by at least one ash cloud that reached $3 \mathrm{~km}$ (10,000 ft; Miller and others, 1998). A poorly documented eruption in 1945 also produced a lava dome that was partially destroyed by the 1974 eruption. Within the past 280 years, a large explosive eruption produced pyroclastic flows that partially filled a valley on the southwest flank (Waythomas and Miller, 2003).

\footnotetext{
Takawangha Volcano

GVP\# 311090

$51.867^{\circ} \mathrm{N} ., 178.027^{\circ} \mathrm{W}$.

$1,449 \mathrm{~m}(4,754 \mathrm{ft})$

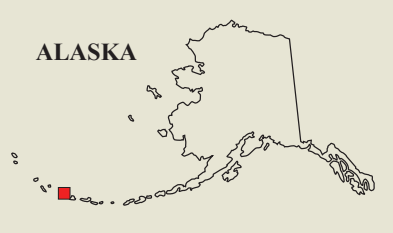

Tanaga Island, Andreanof Islands, Aleutian Islands

\section{EARTHQUAKE SWARM}

Tanaga Island, home to both Tanaga and Takawangha volcanoes, had an earthquake swarm in January 2017 that prompted additional monitoring by AVO staff. On January 23, an energetic earthquake swarm occurred $7 \mathrm{~km}$ (4 mi) eastsoutheast of Takawangha volcano near Gusty Bay (fig. 38), an area where three previous earthquake swarms have been recorded in October 2005, May 2008, and June 2009. AVO raised the Aviation Color Code to YELLOW and Volcano Alert Level to ADVISORY for Takawangha volcano as a precaution. During the first 24 hours of the earthquake swarm, the seismicity waxed and waned. On January 25 , the seismicity began to decline until it approached background
} 


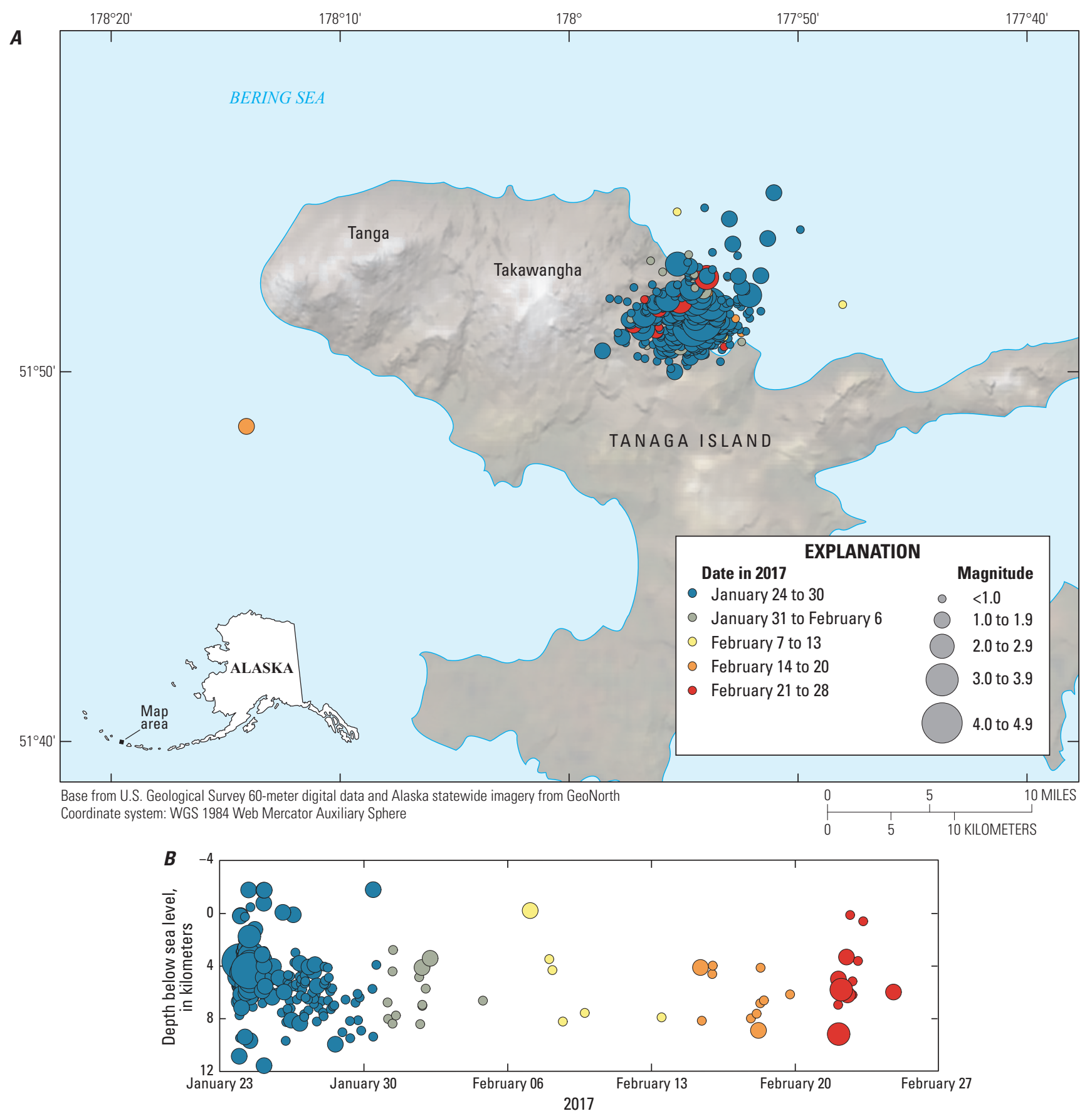

Figure 38. Map $(A)$ and graph $(B)$ earthquake of Tanaga Island showing earthquakes located from January 23 to February 28, 2017. Earthquake symbols are colored by date and size by magnitude.

levels by the end of the month. The earthquakes occurred in a spherical volume at depths between 2 and $8 \mathrm{~km}(1.2$ and 4.8 $\mathrm{mi})$, similar to the three previous swarms. There were four earthquakes of greater than $M_{L} 3$ in the nearly 400 earthquakes located in the brief swarm. On February 8, AVO reduced the Aviation Color Code and Volcano Alert Level to GREEN and NORMAL, respectively, where it remained for the rest of the year. Throughout February a small but significant number of earthquakes continued to be located in the Gusty Bay region. In March seismicity returned to background levels.

Takawangha volcano is a remote, $1,449 \mathrm{~m}(4,754 \mathrm{ft})$ high stratovolcano located on the northeast part of Tanaga Island, roughly $95 \mathrm{~km}$ (59 miles) west of Adak, Alaska, in the Andreanof Islands (fig. 39). Takawangha volcano's summit is mostly ice-covered, except for five young craters that have erupted ash and lava flows in the last few thousand years. Parts 
of the volcano's edifice are hydrothermally altered and may be unstable, which may cause localized debris avalanches from its flanks. Takawangha volcano lies across a topographic saddle from historically active Tanaga Volcano to the west. No historical eruptions are known from Takawangha; however, field work shows that recent eruptions have occurred, and it is possible that historical eruptions attributed to Tanaga may instead have come from Takawangha (Coombs and others, 2007).

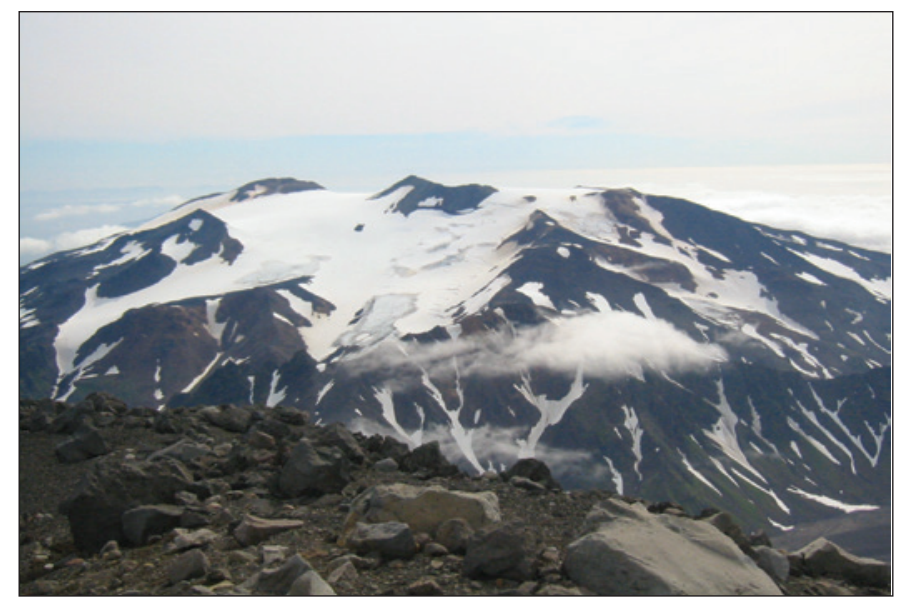

Figure 39. U.S. Geological Survey photograph of Takawahgna volcano from the summit on the east side of Tanaga Volcano on August 28, 2003. Photograph by Michelle Coombs.

\section{Mount Gareloi}

GVP\# 311070

$51.789^{\circ} \mathrm{N} ., 178.794^{\circ} \mathrm{W}$.

$1573 \mathrm{~m}(2,625 \mathrm{ft})$

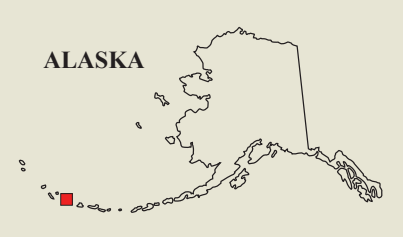

Gareloi Island, Andreanof Islands, Aleutian Islands

\section{GAS PLUME}

On March 28, 2017, a NASA scientist reported that that minor activity had been occurring at Mount Gareloi. An investigation of this observation concluded that there had been no change in the activity at Mount Gareloi but that a weather phenomenon interacted with persistent degassing to form the artifacts in the satellite images that the NASA scientist referenced in his report. The Aviation Color Code and Volcano Alert Level remained at GREEN and NORMAL, respectively.

The amount of located seismicity at Mount Gareloi increased significantly in 2016 and remained elevated in 2017. A tectonic earthquake series 20-30 km (12-18 mi) southeast of Mount Gareloi began in 2016 and increased in activity in 2017. A second tectonic earthquake series, 10-15 km (6-9 mi) west of Mount Gareloi occurred only in 2016 and was nearly absent in 2017. The number of earthquakes on or near Gareloi Island was significantly greater in 2017 with the majority of these earthquakes occurring in a week-long period at the end of November. The ambient noise at the Gareloi Island seismograph stations was low during this time, and a number of small low-frequency earthquakes were located. Earthquakes similar to those in late November 2017 are often too small to be located due to the usually high seismic noise levels and have been detected frequently since the installation of the seismograph network. Independent signs of unrest were not observed coincident with the November swarm or at any time in 2017. The Aviation Color Code and Volcano Alert Level remained at GREEN and NORMAL, respectively.

Mount Gareloi (fig. 40), which makes up most of Gareloi Island, is a stratovolcano $10 \mathrm{~km}(6 \mathrm{mi})$ by $8 \mathrm{~km}(4.8 \mathrm{mi})$ in diameter at its base that consists of two summits, separated by a narrow saddle (Miller and others, 1998). Both summits have been historically active (Coombs and others, 2012), and several prominent fumaroles are active at the south summit. Thirteen younger craters, from 80 to $1600 \mathrm{~m}$ (260 to $5250 \mathrm{ft}$ ) in diameter, are aligned along a south-southeast trending fissure that extends to the south summit. These craters formed during a major explosive eruption in 1929 that also produced four blocky lava flows and a blanket of grassy andesitic tuff that covers an area roughly 2.5 by 5 $\mathrm{km}$ (1.6 by $3.1 \mathrm{mi})$ on the volcano's southeast flank (Coats, 1959).

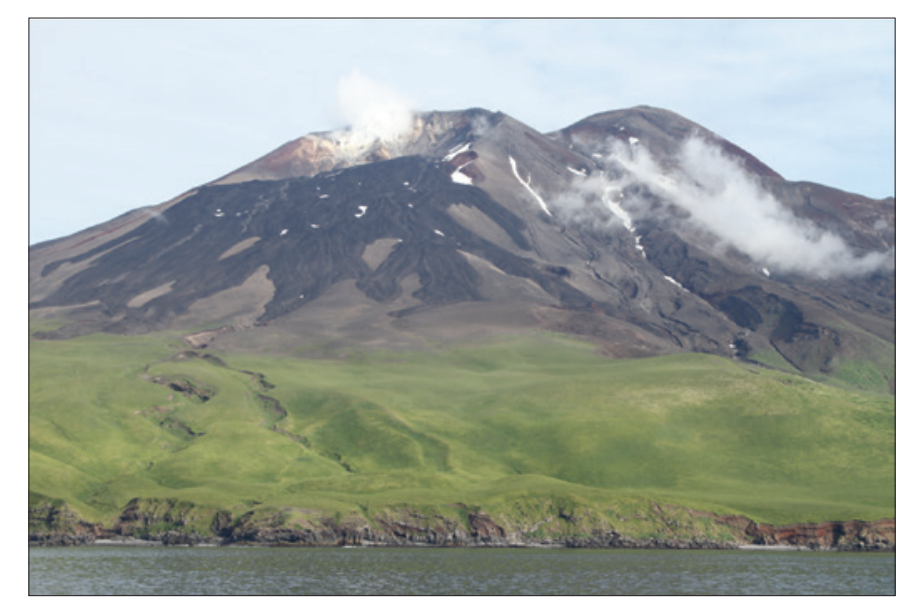

Figure 40. U.S. Geological Survey photograph looking northwest to Mount Gareloi in August 2013. Photograph by Christina Neal.

\section{Kiska Volcano \\ GVP\# 311020 \\ $52.103^{\circ}$ N., $177.604^{\circ} \mathrm{E}$. \\ $1,220 \mathrm{~m}(4,003 \mathrm{ft})$}

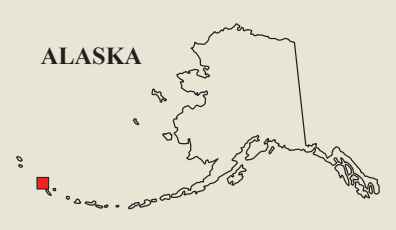

Rat Islands, Aleutian Islands

\section{GAS PLUME}

On November 1, 2017, a commercial airline pilot reported minor smoke coming from the side of an undetermined volcano in the western Aleutian Islands (fig. 41). Descriptions and photos of the observation suggested that the activity was coming from fumaroles on the northwest flank of Kiska Volcano. This activity 
Figure 41. Photograph of Kiska Volcano showing gas plume from fumarolic field on the volcano's northwest flank on November 1, 2017. Photograph by Charles Krogsgaard.

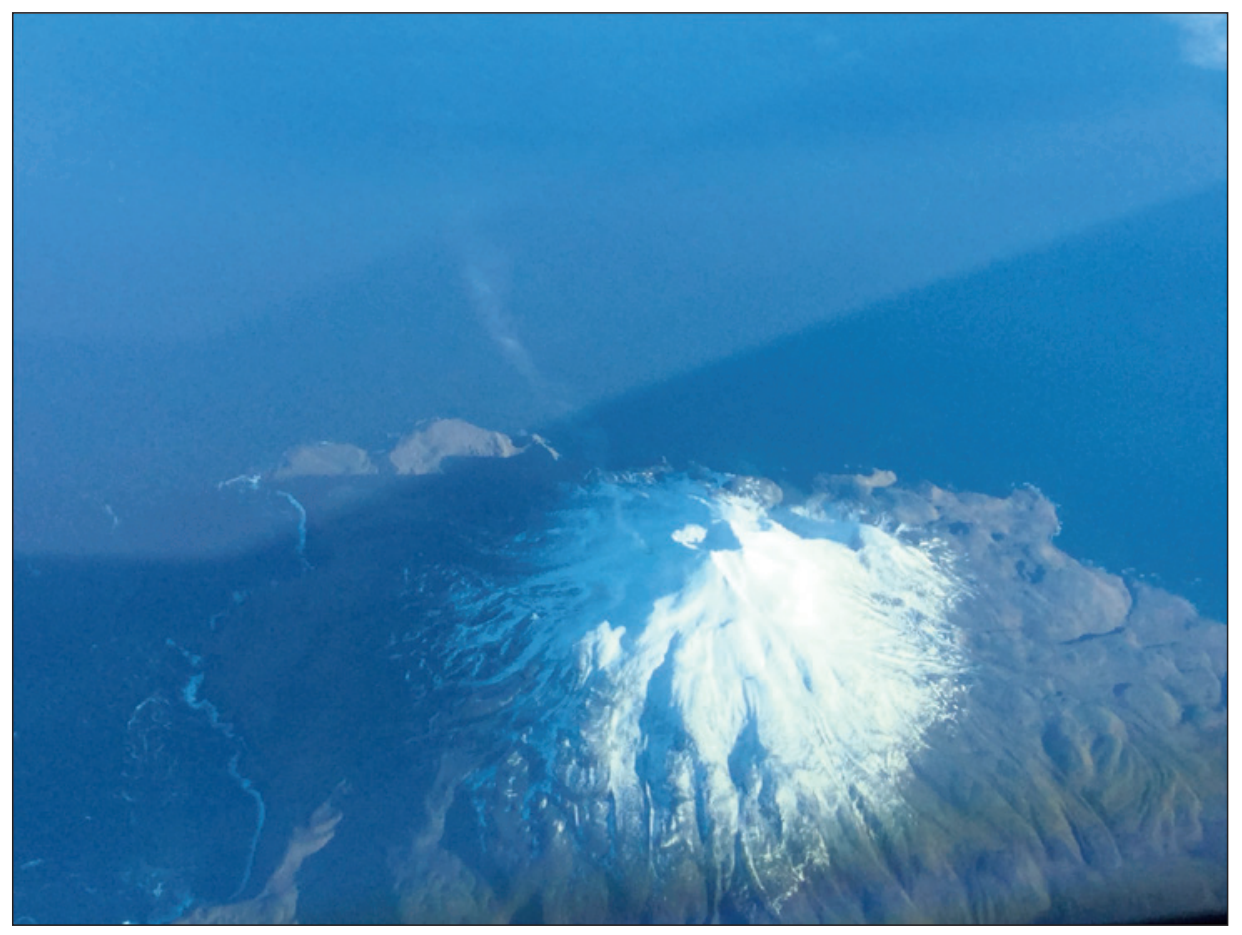

is typical of that known to Kiska Volcano. This fumarole field is documented by AVO and other observers, and degassing has been noted on multiple occasions from this location for decades when scientists conducted field work on Kiska Island. The Aviation Color Code and Volcano Alert Level remained at UNASSIGNED throughout the year for Kiska Volcano.

Kiska Volcano is a stratovolcano, 8.5 by $6.4 \mathrm{~km}$ in diameter at its base, that is situated on the north end of Kiska Island (Miller and others 1998). A slightly elliptical crater, about $0.4 \mathrm{~km}$ in diameter and breached on the north, occupies the volcano summit. A 30-m- (100-ft-) high parasitic cinder cone originally formed in 1962 near sea level at Sirius Point, and an older parasitic cone, now leveled by marine erosion, formed at sea level $5.6 \mathrm{~km}$ (3.4 mi) southwest of the summit of Kiska Volcano. Kiska is underlain and flanked on the south by the remains of an older composite volcano (Marlow and others, 1973) that has been glacially eroded, but the older volcano shows no evidence of glacial dissection (Coats, 1961).

\section{Acknowledgments}

Material presented in this report is based on work supported by the U.S. Geological Survey under Cooperative Agreement No. G19AC00171. This report represents work of the entire Alaska Volcano Observatory staff, colleagues from other USGS Volcano Observatories, cooperating State and Federal agencies, and members of the public. Careful technical reviews by Jessica Ball and Taryn Lopez improved the content and presentation. We particularly thank those who contributed to maintaining the internal chronologies of activity at active volcanic centers.

\section{References Cited}

Begét, J.E., and Kienle, J., 1992, Cyclic formation of debris avalanches at Mount St Augustine volcano: Nature, v. 356, no. 6371, p. 701-704.

Begét, J.E., Larsen, J.F., Neal, C.A., Nye, C.J., and Schaefer, J.R., 2005, Preliminary volcano-hazard assessment for Okmok Volcano, Umnak Island, Alaska: Alaska Division of Geological \& Geophysical Surveys Report of Investigation 2004-3, 32 p., 1 sheet, scale 1:150,000.

Begét, J.E., Nye, C.J., and Bean, K.W., 2000, Preliminary volcano-hazard assessment for Makushin Volcano, Alaska: Alaska Division of Geological \& Geophysical Surveys Report of Investigation 2000-4, 22 p., 1 sheet, scale 1:100,000.

Benoit, J.P., and McNutt, S.R., 1996, Global volcanic earthquake swarm database 1979-1989: U.S. Geological Survey Open File Report 96-69, $333 \mathrm{p}$.

Bull, K.F., and Buurman, H., 2013, An overview of the 2009 eruption of Redoubt Volcano, Alaska: Journal of Volcanology and Geothermal Research, v. 259, p. 2-15. [Also available at, https://doi.org/10.1016/j.jvolgeores.2012.06.024]

Byers, F.M., Jr., 1959, Geology of Umnak and Bogoslof Islands, Aleutian Islands, Alaska, in Investigations of Alaskan volcanoes: U.S. Geological Survey Bulletin 1028-L, p. 267369,5 sheets.

Cameron, C.E., ed., 2005, Alaska Volcano Observatory: U.S. Geological Survey Web site, accessed November 12, 2016, at https://www.avo.alaska.edu. 
Cameron, C.E., Schaefer, J.R., and Mulliken, K.M., 2018, Historically active volcanoes of Alaska: Alaska Division of Geological \& Geophysical Surveys Miscellaneous Publication 133, v. 3, 2 sheets. [Also available at https://doi. org/10.14509/30142]

Coats, R.R., 1959, Geologic reconnaissance of Gareloi Island, Aleutian Islands, Alaska, in Investigations of Alaskan volcanoes: U.S. Geological Survey Bulletin 1928-J, p. 249-256, 1 sheet.

Coats, R.R., Nelson, W.H., Lewis, R.G., and Powers, H.A., 1961, Geologic reconnaissance of Kiska Island, Aleutian Islands, Alaska, in Investigations of Alaskan volcanoes: U.S. Geological Survey Bulletin 1028-R, p. 563-581, 1 sheet, scale 1:63,360.

Coombs, M.L., McGimsey, R.G., and Browne, B.L., 2007, Preliminary volcano-hazard assessment for the Tanaga Volcanic Cluster, Tanaga Island, Alaska: U.S. Geological Survey Scientific Investigations Report 2007-5094, 36 p., https://pubs. usgs.gov/sir/2007/5094.

Coombs, M.L., McGimsey, R.G., and Browne, B.L., 2012, Geologic map of Mount Gareloi, Gareloi Island, Alaska: U.S. Geological Survey Scientific Investigations Map 3145, 18 p., 1 sheet, scale 1:24,000, https://pubs.usgs.gov/sim/3145/.

Coombs, M.L., Wech, A.G., Haney, M.M., Lyons, J.J., Schneider, D.J., Schwaiger, H.F., and Tepp, G., 2018, Shortterm forecasting and detection of explosions during the 2016-2017 eruption of Bogoslof volcano, Alaska: Frontiers in Earth Science, v. 6, p. 1-17. [Also available at, https://doi. org/10.3389/feart.2018.00122]

Coombs, M.L., Wallace, K.L, Cameron, C.E., Lyons, J., Wech, A., Angeli, K., and Cervelli, P., 2019, Overview, chronology, and impacts of the 2016-2017 eruption of Bogoslof volcano, Alaska: Bulletin of Volcanology, v. 81, no., 62, 23 p. [Also available https://doi.org/10.1007/ s00445-019-1322-9]

Dean, K.G., Dehn, J., Papp, K.R., Smith, S., Izbekov, P., Peterson, R., Kearney, C., and Steffke, A., 2004, Integrated satellite observations of the 2001 eruption of Mt. Cleveland, Alaska: Journal of Volcanology and Geothermal Research, v. 135, p. 51-73.

Dixon, J.P., Stihler, S.D., Power, J.A., Haney, M., Lyons, J., Ketner, D., Mulliken, K.M., Parker, T., Searcy, C.K., and Prejean, S., 2019, Catalog of earthquake parameters and description of seismographic and acoustic stations at Alaskan volcanoes - January 1, 2013, through December 31, 2017 : U.S. Geological Survey Data Series 1115, 92 p., https://doi. org/10.3133/ds1115.

Fee, D., Steffke, A., and Garces, M., 2010, Characterization of the 2008 Kasatochi and Okmok eruptions using remote infrasound arrays: Journal of Geophysical Research, v. 115 , no. D00L10, 15 p. [Also available at https://doi. org/10.1029/2009JD013621]
Gardner, C.A., and Guffanti, M.C., 2006, U.S. Geological Survey's alert notification system for volcanic activity: U.S. Geological Survey Fact Sheet 2006-3139, 4 p., https://pubs. usgs.gov/fs/2006/3139.

Hadley, D., Hufford, G.L., and Simpson, J.J., 2004, Resuspension of relic volcanic ash and dust from KatmaiStill an aviation hazard: Weather and Forecasting, v. 19, no. 5, p. 829-840.

Haney, M.M., Van Eaton, A.R., Lyons, J.J., Kramer, R.L., Fee, D., and Iezzi, A.M., 2018, Volcanic Thunder From Explosive Eruptions at Bogoslof Volcano, Alaska: Geophysical Research Letters, v. 45, no. 8, p. 3429-3435. [Also available at https://doi.org/10.1002/2017GL076911]

Hildreth, W., and Fierstein, J., 2012, The Novarupta-Katmai eruption of 1912-Largest eruption of the twentieth century: Centennial perspectives: U.S. Geological Survey Professional Paper 1791, 259 p., https://pubs.usgs.gov/ $\mathrm{pp} / 1791$.

Keith, T.E.C., ed., 1995, The 1992 eruptions of Crater Peak Vent, Mount Spurr volcano, Alaska: U.S. Geological Survey Bulletin B 2139, 220 p.

Larsen, J.F., Neal, C., Schaefer, J., Beget, J., and Nye, C., 2007, Late Pleistocene and Holocene caldera-forming eruptions of Okmok Caldera, Aleutian Islands, Alaska, in Eichelberger, J., Gordeev, E., Izbekov, P., Kasahara, M., and Lees, J., eds., Volcanism and subduction-The Kamchatka region: American Geophysical Union, Geophysical Monograph 172, p. 343-364.

Lopez, T., Cairn, S., Werner, C., Fee, D., Kelly, P., Doukas, M., Pfeffer, M., Webley, P., Cahill, C., and Schneider, D., 2013, Evaluation of Redoubt Volcano's sulfur dioxide emissions by the Ozone Monitoring Instrument: Journal of Volcanology and Geothermal Research, v. 259, p. 290-307.

Lee, Chang-Wook, Lu, Z., Jung, Hyung-Sup, Won, Joong-Sun, and Dzurisin, D., 2010, Surface deformation of Augustine Volcano, 1992-2005, from multiple-interferogram processing using a refined small baseline subset (SBAS) interferometric synthetic aperture radar (InSAR) approach, chap. 18 of Power, J.A., Coombs, M.L., and Freymueller, J.T., eds., The 2006 eruption of Augustine Volcano, Alaska: U.S. Geological Survey Professional Paper 1769, p. 453-465.

Lu, Z., Wicks, C., Power, J.A., and Dzurisin, D., 2000, Ground deformation associated with the March 1996 earthquake swarm at Akutan volcano, Alaska, revealed by satellite radar interferometry: Journal of Geophysical Research, v. 105, no. B9, p. 21,483-21,496.

Marlow, M.S., Scholl, D.W., Buffington, E.C., and Alpha, T.R., 1973, Tectonic history of the central Aleutian Arc: Geological Society of America Bulletin, v. 84, no. 5, p. 1,555-1,574. 
McConnell, V.S., Beget, J.E., Roach, A.L., Bean, K.W., and Nye, C.J., 1998, Geologic map of the Makushin volcanic field, Unalaska Island, Alaska: Alaska Division of Geological \& Geophysical Surveys Report of Investigation 97-20, 2 sheets, scale 1:63,360. [Also available at https://doi.org/10.14509/2576]

McGimsey, R.G., Neal, C.A., and Doukas, M.P., 1995, Volcanic activity in Alaska: Summary of events and response of the Alaska Volcano Observatory 1992: U.S. Geological Survey Open-File Report 95-83, 26 p.

McGimsey, R.G., and Neal, C.A., 1996, 1995 Volcanic activity in Alaska and Kamchatka - Summary of events and response of the Alaska Volcano Observatory: U.S. Geological Survey OpenFile Report 96-738, 23 p., https://doi.org/10.3133/ofr96738.

McGimsey, R.G., Neal, C.A., and Girina, O., 2005, 2003 Volcanic activity in Alaska and Kamchatka - Summary of events and response of the Alaska Volcano Observatory: U.S. Geological Survey Open-File Report 2005-1310, 62 p.

Miller, T.P., and Chouet, B.A., 1994, The 1989-1990 eruptions of Redoubt volcano-An introduction, in Miller, T.P. and Chouet, B.A., eds., The 1989-1990 eruptions of Redoubt Volcano, Alaska: Journal of Volcanology and Geothermal Research, v. 62, no. 1, p. 1-10.

Miller, T.P., McGimsey, R.G., Richter, D.H., Riehle, J.R., Nye, C.J., Yount, M.E., and Dumoulin, J.A., 1998, Catalog of the historically active volcanoes of Alaska: U.S. Geological Survey Open-File Report 98-0582, 104 p., https://doi.org/10.3133/ ofr98582.

Neal, C.A., McGimsey, R.G., Dixon, J.P., Cameron, C.E., Nuzhaev, A.A., and Chibisova, M., 2011, 2008 Volcanic activity in Alaska, Kamchatka, and the Kurile Islands - Summary of events and response of the Alaska Volcano Observatory: U.S. Geological Survey Scientific Investigations Report 2010-5243, 94 p., https://pubs.usgs.gov/sir/2010/5243.

Nye, C.J., and Turner, D.L., 1990, Petrology, geochemistry, and age of the Spurr volcanic complex, eastern Aleutian arc: Bulletin of Volcanology, v. 52, no. 3, p. 205-226.

Power, J.A., Stihler, S.D., White, R., and Moran, S.C. 2004, Observations of Deep Long-Period (DLP) Seismic Events Beneath Aleutian Arc Volcanoes; 1989 to 2002, Journal of Volcanology and Geothermal Research, v. 138, no. 3-4, p. 243-266. [Also available at https://doi.org/10.1016/j. jvolgeores.2004.07.005]

Prejean, S.G., Werner, C.A., Buurman, H., Doukas, M.P., Kelly, P.J., Kern, C., Ketner, D.M., Stihler, S.D., Thurber, C.H., and West, M.E., 2012, Seismic and gas analyses imply magmatic intrusion at Iliamna Volcano, Alaska in 2012 [abs.]: Eos, Transactions, American Geophysical Union, Fall meeting supplement, Abstract number V53B-2826.
Richter, D.H., Waythomas, C.F., McGimsey, R.G., and Stelling, P.L., 1998, Geologic map of Akutan Island, Alaska: U.S. Geological Survey Open-File Report 98-0135, 22 p., 1 sheet, scale 1:48,000.

Riehle, J.R., 1985, A reconnaissance of the major Holocene tephra deposits in the upper Cook Inlet region, Alaska: Journal of Volcanology and Geothermal Research, v. 26, no. 1-2, p. 37-74.

Roman, D.C., Power, J.A., Moran, S.C., Cashman, K.V., Doukas, M.P., Neal, C.A., and Gerlach, T.M., 2004, Evidence for dike emplacement at Iliamna Volcano, Alaska in 1996: Journal of Volcanology and Geothermal Research v. 130 , p. 265-284.

Schaefer, J.R., ed., 2011, The 2009 eruption of Redoubt Volcano, Alaska, with contributions by Bull, K.F., Cameron, C.E., Coombs, M.L., Diefenbach, A.K., Lopez, Taryn, McNutt, S.R., Neal, C.A., Payne, A.L., Power, J.A., Schneider, D.J., Scott, W.E., Snedigar, S.F, Thompson, G., Wallace, K.L., Waythomas, C.F., Webley, P.W., and Werner, C.A.: Alaska Division of Geological \& Geophysical Surveys Report of Investigation 2011-5, 45 p. [Also available at http://www.dggs.alaska.gov/ pubs/id/23123]

Siebert, L., Simkin, T., and Kimberly, P., 2010, Volcanoes of the world (3d ed.): Berkley, Calif., University of California Press, $568 \mathrm{p}$.

Waythomas, C.F., 2007, Mid-Holocene sector collapse at Mount Spurr volcano, South-central Alaska, in Haeussler, P.J., and Galloway, J.P., eds., Studies by the U.S. Geological Survey in Alaska, 2006: U.S. Geological Survey Professional Paper 1739-C, $15 \mathrm{p}$.

Waythomas, C.F., and Cameron, C.E., 2018, Historical eruptions and hazards at Bogoslof volcano, Alaska: U.S. Geological Survey Scientific Investigations Report 2018-5085, 42 p.

Waythomas, C.F., Dorava, J.M., Miller, T.P., Neal, C.A., and McGimsey, R.G., 1997, Preliminary volcano-hazard assessment for Redoubt Volcano, Alaska: U.S. Geological Survey OpenFile Report 97-857, 40 p., 1 pl., https://doi.org/10.3133/ ofr97857.

Waythomas, C.F., and Miller, T.P., 1999, Preliminary volcanohazard assessment for Iliamna Volcano, Alaska: U.S. Geological Survey Open-File Report 99-0373, 31 p., 1 sheet, scale unknown.

Waythomas, C.F., and Miller, T.P., 2003, Preliminary hazard report for Great Sitkin: U.S. Geological Survey Open File Report 03-112, $25 \mathrm{p}$.

Waythomas, C. F., Miller, T. P., and Nye, C. J., 2003, Preliminary geologic map of Great Sitkin Volcano, Alaska: U.S. Geological Survey Open-File Report OF 03-0036, 1 sheet, scale 1:63,360. 
Waythomas, C.F., and Nye, C.J., 2002, Preliminary volcanichazard assessment for Mount Spurr volcano, Alaska; U.S. Geological Survey Open File Report 01-0482, 46 p.

Waythomas, C.F., Power, J.A., Richter, D.H., and McGimsey, R.G., 1998, Preliminary volcano-hazard assessment for Akutan volcano, east-central Aleutian Islands, Alaska: U.S. Geological Survey Open-File Report 98-0360, 36 p., 1 plate, scale unknown.
Waythomas, C.F., Lyons, J.J., Fee, D., and Wallace, K.L., 2019, The 2016-2017 eruption of Bogoslof volcano, Alaska; preface to the special issue, Bulletin of Volcanology, v. 81, no. 48, 2 p.

[Also available at https://doi.org/10.1007/s00445-019-1301-1]

Werner, C.A., Doukas, M.P., and Kelly, P.J., 2011, Gas emission from failed and actual eruptions from Cook Inlet volcanoes, Alaska, 1989-2006: Bulletin of Volcanology, v. 73, no. 2, p. 155-173, https://doi.org/10.1007/s00445-011-0453-4. 


\section{Glossary of Selected Terms and Acronyms}

andesite Volcanic rock composed of about 53-63 percent silica ( $\mathrm{Si}_{2}$, an essential constituent of most minerals found in rocks).

ash Fine fragments (less than 2 millimeters across) of lava or rock formed in an explosive volcanic eruption.

caldera A large, roughly circular depression usually caused by volcanic collapse or explosion.

fallout A general term for debris, which falls to the Earth from an eruption cloud.

fissure A roughly linear or sinuous crack or opening on a volcano; a type of vent, which commonly produces lava fountains and flows.

fumarole A small opening or vent from which hot gases are emitted.

Holocene Geologic epoch extending from the present to 10,000 years ago.

infrasound Low-frequency sound waves, below the threshold of human hearing.

intracaldera Refers to something within the caldera.

juvenile Volcanic material created from magma reaching the surface.

lahar A flow of a mixture of pyroclastic material and water.

Landsat 8 An American earth observation satellite; the eighth in the Landsat program.

lava Molten rock that has reached the Earth's surface.

low-frequency earthquakes Earthquakes with dominant frequencies between 1 and $5 \mathrm{~Hz}$.

$\mathbf{M}_{\mathbf{L}}$ An earthquake magnitude scale based on the amplitude of ground motion as measured by a standard seismograph.

magma Molten rock below the surface of the Earth. phreatic activity An explosive eruption caused by the sudden heating of ground water as it comes in contact with hot volcanic rock or magma leading to a gas-driven explosion. phreatic ash Fine fragments of volcanic rock expelled during phreatic activity; this ash usually is derived from existing rock and not from new magma.

pixel Contraction of "picture element." A pixel is one of the many discrete rectangular elements that form a digital image or picture on a computer monitor or stored in memory. In a satellite image, resolution describes the size of a pixel in relation to area covered on the ground. More pixels per unit area on the ground mean a higher resolution.

pyroclast An individual particle ejected during a volcanic eruption; usually classified by size, for example, ash, lapilli.

regional earthquake Earthquake generated by fracture or slippage along a fault; not caused by volcanic activity.

satellite A subsidiary volcanic vent located on the flank of a larger volcano.

seismic swarm A flurry of closely spaced earthquakes or other ground shaking activity; often precedes an eruption.

spatter cone A low, steep-sided cone of spatter built up on a fissure or vent.

stratovolcano Also called a stratocone or composite cone, a steep-sided volcano, usually conical in shape, built of interbedded lava flows and fragmental deposits from explosive eruptions.

Strombolian Type of volcanic eruption characterized by intermittent bursts of fluid lava, usually basalt, from a vent or crater as gas bubbles rise through a conduit and burst at the surface.

Surtseyan eruption A type of phreatomagmatic eruption that often takes place in shallow water seas.

tremor Low-amplitude, continuous earthquake activity often associated with magma movement. vent An opening in the earth's surface through which magma erupts or volcanic gasses are emitted. 


\section{Appendix 1. Volcano Alert Levels and Aviation Color Codes Used by United States Volcano Observatories}

Alert levels address the overall activity at the volcano, not just the hazard to aviation. There may be situations where a volcano is producing lava flows that are dangerous on the ground and merit a WATCH or WARNING, however, the hazard to aviation is minimal. Alert levels announcements contain additional explanation of volcanic activity and expected hazards where possible (Gardner and Guffanti, 2006).

\begin{tabular}{|c|c|}
\hline \multicolumn{2}{|r|}{ Volcano Alert Levels } \\
\hline NORMAL & $\begin{array}{l}\text { Volcano is in typical background, noneruptive state. } \\
\text { Or, after a change from a higher level: } \\
\text { Volcanic activity has ceased, and volcano reverted to its noneruptive state. }\end{array}$ \\
\hline ADVISORY & $\begin{array}{l}\text { Volcano is exhibiting signs of elevated unrest above known background level. } \\
\text { Or, after a change from a higher level: } \\
\text { Volcanic activity has decreased significantly but continues to be closely monitored for possible renewed increase. }\end{array}$ \\
\hline WARNING & Highly hazardous eruption is imminent, underway, or suspected. \\
\hline
\end{tabular}

\section{Aviation Color Codes}

GREEN

Volcano is in typical background, noneruptive state.

Or, after a change from a higher level:

Volcanic activity has ceased, and volcano reverted to its noneruptive state.

YELLOW Or, after a change from a higher level:

Volcano is exhibiting signs of elevated unrest above known background level.

Volcanic activity has decreased significantly but continues to be closely monitored for possible renewed increase.

ORANGE

Volcano is exhibiting heightened or escalating unrest with increased potential of eruption, timeframe uncertain.

Or:

Eruption is underway but poses limited hazards.

Eruption is imminent with significant emission of volcanic ash into the atmosphere likely.

Or:

Eruption is underway or suspected with significant emission of volcanic ash into the atmosphere (ash-plume height specified, if possible). 


\section{Appendix 2. Compilation of volcanoes included in Alaska Volcano Observatory Annual Summaries by year, 1992-2017.}

Table 2.1. Compilation of volcanoes included in Alaska Volcano Observatory Annual Summaries by year $1992-2017$.

[Volcanoes are presented in geographical order from northeast to southwest along the Wrangell-Aleutian volcanic arc]

\begin{tabular}{lc}
\hline \multicolumn{1}{c}{ Volcanoes mentioned } \\
\hline Spurr/Crater Peak \\
Iliamna \\
Redoubt \\
Katmai Group (Mageik) \\
Westdahl \\
Akutan \\
Bogoslof \\
Seguam \\
\hline
\end{tabular}

Churchill

\begin{tabular}{l}
\multicolumn{1}{c}{ Volcanoes mentioned } \\
\hline Amukta \\
Korovin (Atka) \\
Kanaga \\
\hline \multicolumn{1}{c}{1997} \\
\hline Wrangell \\
Sanford \\
Shrub Mud \\
Iliamna \\
Katmai Group (Martin, Mageik, Snowy, and Kukak) \\
Chiginagak \\
Pavlof \\
Shishaldin \\
Okmok \\
Cleveland \\
Amukta
\end{tabular}

Sanford

Spurr/Crater Peak

Veniaminof

Shishaldin

Makushin

Seguam

Kliuchef (Atka Island)

Kanaga

\begin{tabular}{l}
\hline \multicolumn{1}{c}{1994} \\
\hline Sanford \\
Iliamna \\
Katmai Group (Martin, Mageik, and Trident) \\
Veniaminof \\
Kupreanof \\
Shishaldin \\
Makushin \\
Cleveland \\
Kanaga \\
\hline
\end{tabular}

Katmai Group (Martin)

Veniaminof

1998

Shrub Mud

Augustine

Becharof Lake

Chiginagak

Shishaldin

Akutan

Korovin (Atka Island)

\begin{tabular}{l}
\hline \multicolumn{1}{l}{1999} \\
\hline Wrangell \\
Shrub Mud \\
Iliamna \\
Veniaminof \\
Pavlof \\
Shishaldin \\
Vsevidof \\
\hline Wrangell \\
Katmai Group (Snowy) \\
Chiginagak \\
Shishaldin \\
\hline Katmai Group (Snowy and Kukak) \\
Pavlof \\
Frosty \\
Shishaldin \\
Makushin \\
Okmok \\
Cleveland
\end{tabular}


Table 2.1.-Continued

\begin{tabular}{l}
\hline \multicolumn{1}{c}{ Volcanoes mentioned } \\
\hline \multicolumn{1}{c}{2002} \\
\hline Wreat Sitkin \\
Katmai Group (Martin and Mageik) \\
Veniaminof \\
Mount Hague (Emmons Lake Caldera) \\
Shishaldin \\
Great Sitkin \\
\hline Wrangell \\
Redoubt \\
Iliamna \\
Augustine \\
Katmai Group (Mageik) \\
Veniaminof \\
Pavlof \\
Mount Hague (Emmons Lake Caldera) \\
Shishaldin \\
Akutan \\
\hline Crillon (non-volanicpeak)
\end{tabular}

\begin{tabular}{lc}
\hline & Volcanoes mentioned \\
\hline Kasatochi & 2007 \\
\hline Redoubt & \\
Augustine & \\
Fourpeaked & \\
Veniaminof & \\
Pavlof & \\
Akutan & \\
Cleveland & \\
Korovin & \\
\hline & \\
\hline Redoubt & \\
Aniakchak & \\
Veniaminof & \\
Shishaldin & \\
Okmok & \\
Cleveland & \\
Kasatochi & \\
\hline & \\
\hline Sanford & \\
Redoubt & \\
Fourpeaked & \\
Aniakchak & \\
Veniaminof & \\
Shishaldin Volcano & \\
Okmok & \\
Cleveland & \\
\hline
\end{tabular}

Crillon (non-volcanic peak)

Spurr

Katmai Group (Martin)

Veniaminof

Spurr

Wrangell

Augustine

Sanford

Katmai Group (Martin)

Chiginagak

Aniakchak

Veniaminof

Pavlof and Hague

Shishaldin

Cleveland

Redoubt

Fourpeaked

Katmai Group (Martin)

Becharof Lake

Aniakchak

Veniaminof

Westdahl

Korovin

Makushin

Kasatochi

Cleveland

Tanaga

2006

Kasatochi

Klawasi Mud

2011

Spurr

Augustine

Fourpeaked

Katmai Group (Martin)

Veniaminof

Wrangell

Sanford

Redoubt

Fourpeaked

Aniakchak

Veniaminof

Cleveland

Makushin

Korovin

Westdahl 
Table 2.1.-Continued

\begin{tabular}{l}
\hline \multicolumn{1}{c}{ Volcanoes mentioned } \\
\hline Cleveland \\
Kasatochi \\
\hline \\
\hline Wrangell \\
Spurr \\
Redoubt \\
Iliamna \\
Augustine \\
Fourpeaked \\
Katmai Group (Martin) \\
Aniakchak \\
Cleveland \\
Kanaga \\
Little Sitkin \\
\hline
\end{tabular}

Wrangell
Redoubt
Iliamna
Augustine
Fourpeaked
Peulik
Aniakchak
Veniaminof
Pavlof
Shishaldin
Akutan
Makushin
Okmok
Cleveland
Korovin Volcano
Great Sitkin
Gareloi

2014

Spurr

\begin{tabular}{l}
\hline \multicolumn{1}{c}{ Volcanoes mentioned } \\
\hline Semisopochnoi 2015 \\
\hline Spurr \\
Redoubt \\
Augustine \\
Iliamna \\
Katmai Group (Katmai, Novarupta) \\
Ugashik and Peulik \\
Aniakchak \\
Veniaminof \\
Kupreanof \\
Pavlof \\
Shishaldin \\
Recheshnoi \\
Cleveland \\
Semisopochnoi
\end{tabular}

\begin{tabular}{l}
\hline \\
Wrangell \\
Spurr \\
Iliamna \\
Augustine \\
Fourpeaked \\
Katmai Group (Novarupta) \\
Aniakchak \\
Pavlof \\
Frosty \\
Shishaldin \\
Makushin \\
Bogoslof \\
Okmok \\
Cleveland \\
Korovin \\
\hline \\
\hline Spurr \\
Redoubt \\
Iliamna \\
Augustine \\
Katmai (Novarupta) \\
Pavlof \\
Shishaldin \\
Akutan \\
Makushin \\
Bogoslof \\
Okmok \\
Cleveland \\
\hline
\end{tabular}


Table 2.2. Compilation by volcano for particular years included in Alaska Volcano Observatory Annual Summaries, 1992-2017.

[Volcanic centers are listed in geographical order from northeast to southwest along the Wrangell-Aleutian volcanic arc. Virgules are used when the exact source of activity is unknown. $\mathrm{CO}_{2}$, carbon dioxide; PIREP, pilot weather report]

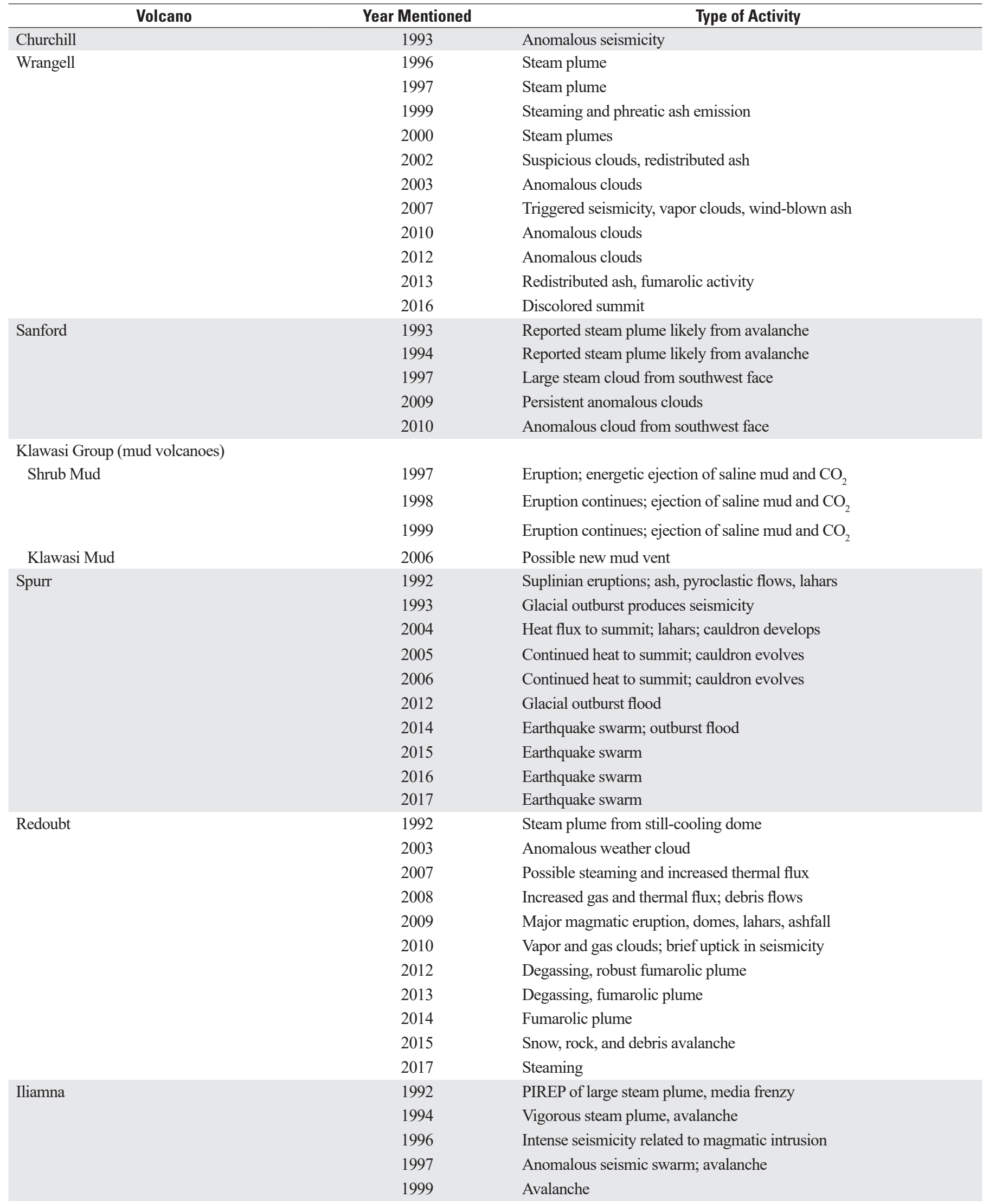


Table 2.2.-Continued

\begin{tabular}{|c|c|c|}
\hline Volcano & Year Mentioned & Type of Activity \\
\hline \multirow[t]{6}{*}{ Iliamna-Continued } & 2003 & Avalanche \\
\hline & 2005 & Rock avalanche \\
\hline & 2013 & Avalanches \\
\hline & 2014 & Avalanches \\
\hline & 2015 & Large tectonic earthquake \\
\hline & 2017 & Minor snow and debris flow \\
\hline \multirow[t]{6}{*}{ Augustine } & 1998 & 1986 dome spine partially collapses, generates mudflow \\
\hline & 2005 & Precursory activity prior to eruption in early 2006 \\
\hline & 2006 & Explosive and effusive eruption \\
\hline & 2007 & Strong seismicity and steam plumes \\
\hline & 2016 & Seismic swarm \\
\hline & 2017 & Seismic activity \\
\hline \multirow[t]{7}{*}{ Fourpeaked } & 2006 & Phreatic eruption \\
\hline & 2007 & Ongoing fumarolic emissions, seismicity \\
\hline & 2009 & Continued decline in gas emissions \\
\hline & 2010 & Decreasing fumarolic emissions, sporadic earthquake swarms \\
\hline & 2012 & Increased seismicity \\
\hline & 2013 & Increased seismicity, anomalous plume \\
\hline & 2016 & Seismic swarm \\
\hline \multicolumn{3}{|l|}{ Katmai Group } \\
\hline Snowy and Kukak & 2001 & Steaming hole in glacier \\
\hline Martin and Mageik & 2002 & Steam plume \\
\hline Mageik & 2003 & Steaming, large cloud of resuspended ash \\
\hline \multirow[t]{5}{*}{ Martin } & 2004 & Large steam plume \\
\hline & 2005 & Steam cloud, resuspended ash, new crater? \\
\hline & 2006 & Earthquake swarm \\
\hline & 2010 & Resuspended ash \\
\hline & 2012 & Elevated seismicity, fumarolic plumes \\
\hline Katmai, Novarupta, and Martin & 2014 & Resuspended 1912 ash; earthquake swarm, vapor plume \\
\hline \multirow[t]{3}{*}{ Katmai and Novarupta } & 2015 & Resuspended 1912 ash \\
\hline & 2016 & Resuspension of $1912 \mathrm{ash}$; deployment of particulate monitors \\
\hline & 2017 & Resuspended 1912 ash \\
\hline \multirow[t]{2}{*}{ Becharof Lake } & 1998 & Intense seismic swarm and inflationary episode \\
\hline & 2010 & Earthquake swarm \\
\hline \multirow[t]{2}{*}{ Ugashik and Peulik } & 2013 & Reported steaming, sulfur odors \\
\hline & 2015 & Discolored water, large earthquake \\
\hline \multirow[t]{3}{*}{ Chiginagak } & 1997 & Minor eruptive activity, new fumarole field \\
\hline & 1998 & Continuation of increased fumarolic activity \\
\hline & 2000 & Steam emissions from fumarole field \\
\hline
\end{tabular}


Table 2.2.-Continued

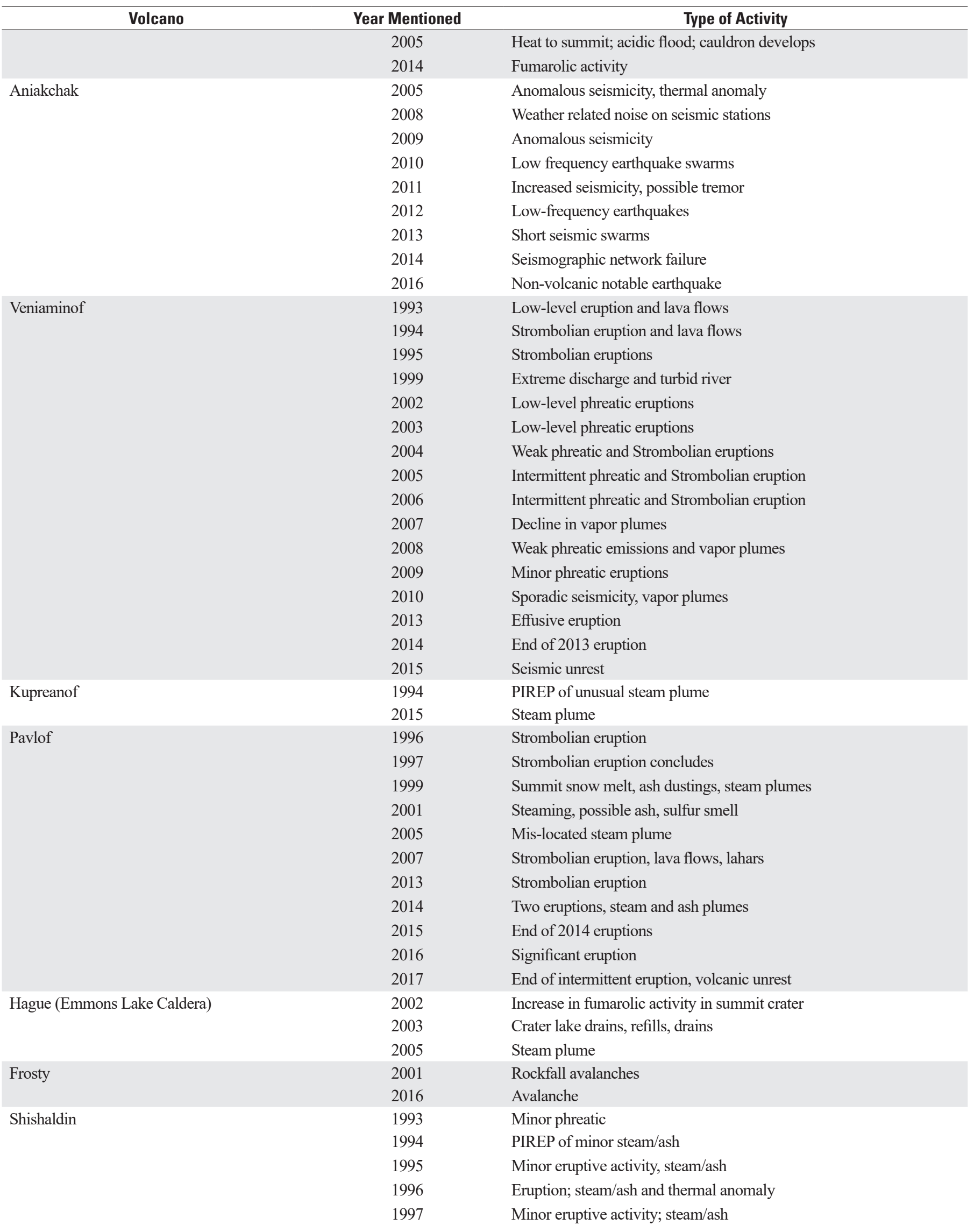


Table 2.2.-Continued

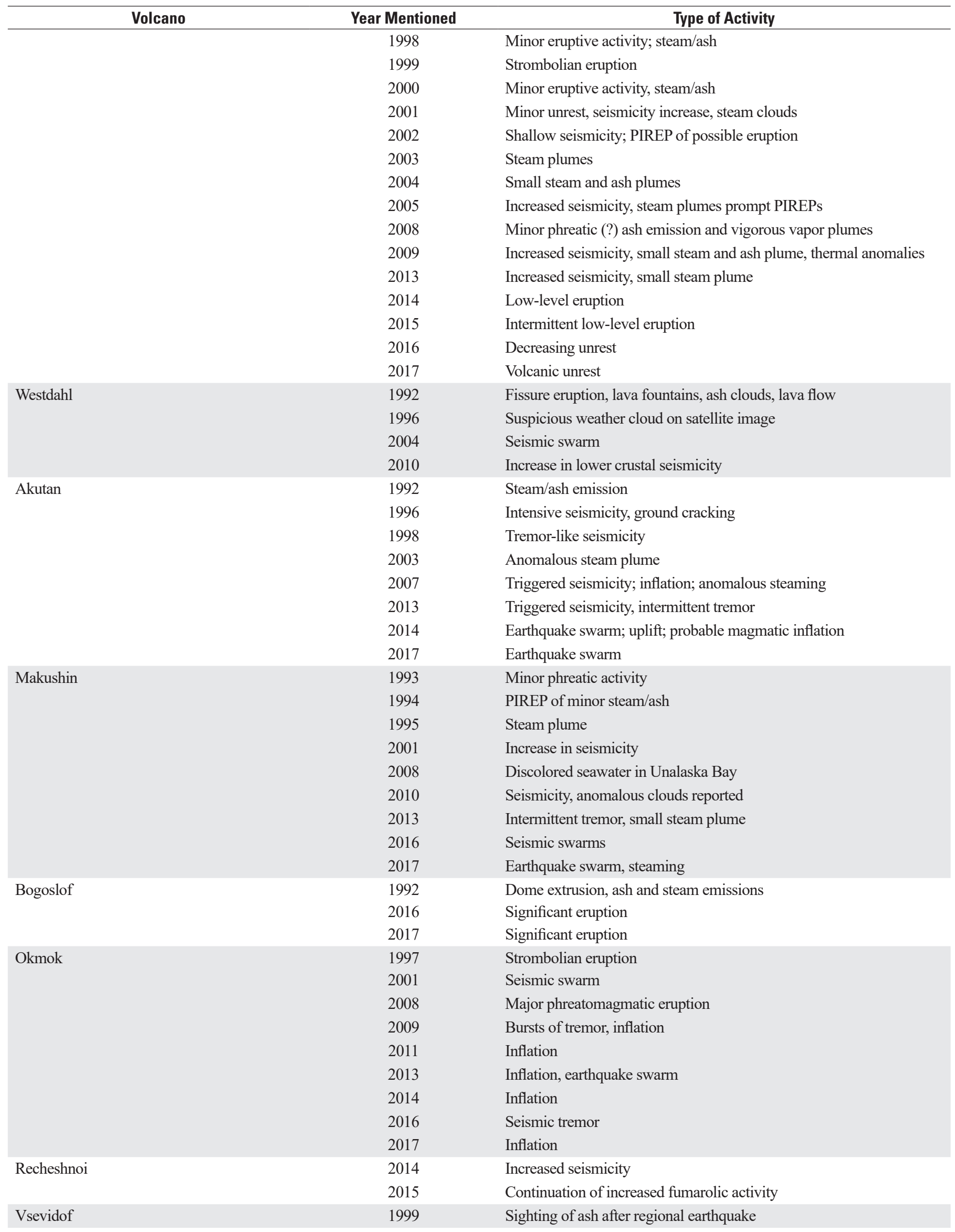


Table 2.2.-Continued

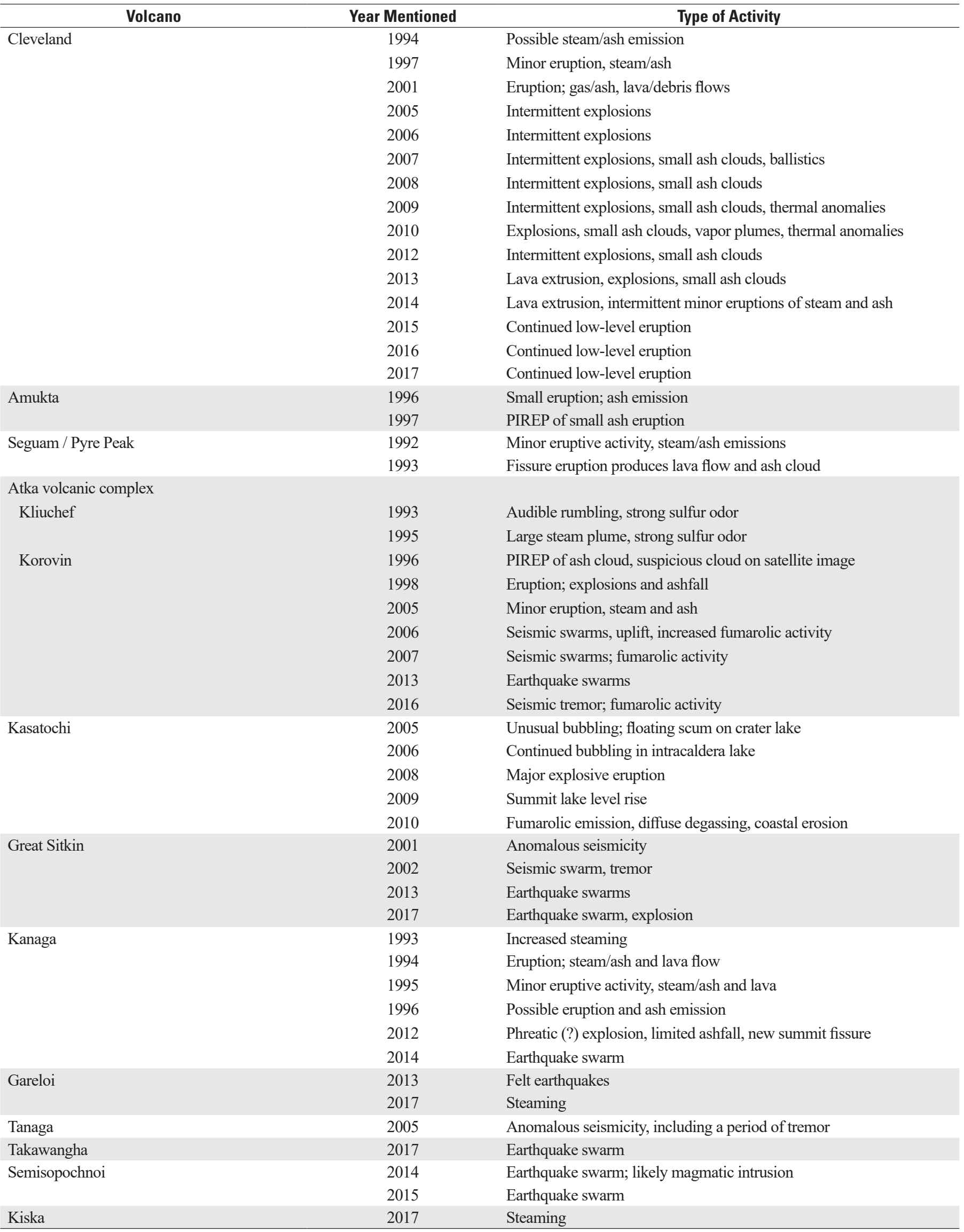


Menlo Park Publishing Service Center, California

Manuscript approved for publication September 1, 2020

Edited by Phil A. Frederick

Cartography and illustration support by JoJo Mangano

Layout and design by Cory Hurd and Kimber Petersen 
을

罯

芑

悉

政

을

逽

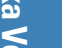

음

움

旁

कs

亭

$\frac{\sigma}{\bar{\alpha}}$

鱼.

产.

$\frac{\pi}{0}$
$\frac{0}{7}$

次

옴 